\title{
In-Situ Surface Deformation and IR Emission Measurements for Solid Oxide Fuel Cells
}

\author{
Huang Guo \\ West Virginia University
}

Follow this and additional works at: https://researchrepository.wvu.edu/etd

\section{Recommended Citation}

Guo, Huang, "In-Situ Surface Deformation and IR Emission Measurements for Solid Oxide Fuel Cells" (2012). Graduate Theses, Dissertations, and Problem Reports. 3570.

https://researchrepository.wvu.edu/etd/3570

This Dissertation is protected by copyright and/or related rights. It has been brought to you by the The Research Repository @ WVU with permission from the rights-holder(s). You are free to use this Dissertation in any way that is permitted by the copyright and related rights legislation that applies to your use. For other uses you must obtain permission from the rights-holder(s) directly, unless additional rights are indicated by a Creative Commons license in the record and/ or on the work itself. This Dissertation has been accepted for inclusion in WVU Graduate Theses, Dissertations, and Problem Reports collection by an authorized administrator of The Research Repository @ WVU.

For more information, please contact researchrepository@mail.wvu.edu. 


\title{
In-Situ Surface Deformation and IR Emission Measurements for Solid Oxide Fuel Cells
}

\author{
Huang Guo
}

Dissertation submitted to the

Benjamin M. Stalter College of Engineering and Mineral

Resources

at West Virginia University

in partial fulfillment of the requirements

for the degree of

Doctor of Philosophy

In Mechanical Engineering

Bruce S. Kang, Ph.D., Chair and Advisor

Ismail Celik, Ph.D.

Harry O. Finklea, Ph.D.

Nianqiang Wu, Ph.D.

Randall Gemmen, Ph.D.

Ayyakkannu Manivannan, Ph.D.

Department of Mechanical and Aerospace Engineering

Morgantown, West Virginia

2012

Keywords: SOFC; In-situ measurement; Laser Optics

Copyright 2012 Huang Guo 


\section{ABSTRACT}

\section{In-Situ Surface Deformation and IR Emission Measurements for Solid Oxide Fuel Cells}

\section{Huang Guo}

Direct utilization of coal syngas in solid oxide fuel cells (SOFCs) can potentially be an efficient technology for next generation clean power generation. Long-term durability is an important requirement for the application of SOFC technology. The useful working life of SOFCs depends on the material degradation which is due to the aggressive environment at the operating conditions. In addition to the electrochemical performance, the mechanical integrity of the fuel cell anode is also essential for successful long-term operation.

Material degradation may occur due to several mechanisms depending on the environment and loading conditions. It is reported that SOFC anodes are susceptible to the attack of coal syngas contaminants (such as S, P, As, etc), which can degrade the electrochemical performance and structural integrity of electrode materials. The SOFC anodes are also subjected to stresses at high temperature, thermal/redox cycles effects during long-term operation. In order to identify such degradation mechanisms and to determine the effects of those mechanisms on the long-term operation of SOFCs, a powerful in-situ test technique that can provide structural and electrochemical details under conditions of actual fuel cell operation is extremely attractive and necessary.

The goal of this research is to develop an enabling technology that integrates Sagnac interferometry and infrared thermometry for in-situ anode surface deformation, electrode surface reaction investigation and surface temperature measurement for SOFCs. The experimental results obtained under different operating conditions, such as hydrogen, simulated coal syngas, with or without trace contaminants (e.g. P) are utilized to validate 
and develop SOFC electrochemical and structural models for long-term prediction of the SOFC integrity under the operating conditions. The experimental setup developed in this research, is also utilized to estimate the material parameters for an SOFC anode material durability model, which incorporates thermo-mechanical and fuel gas contaminants degradation mechanisms, to predict the long-term structural integrity of SOFC anodes.

Keywords: solid oxide fuel cell; Ni-YSZ degradation; coal syngas; phosphine; in-situ measurement; optical technique; surface deformation 


\section{Acknowledgement}

I would like to dedicate this dissertation to my family, especially my wife Danbo Guo, for their constant support during my study.

I am sincerely grateful to Dr. Bruce S. Kang for his guidance of the whole research project. He has been a great support throughout my doctorate program in both academic and extracurricular activities. I am glad to have the opportunity to finish the doctoral degree under his guidance.

I would also thank all my committee members: Dr. Ismail Celik, Dr. Nianqiang Wu, Dr. Harry O. Finklea, Dr. Randall Gemmen and Dr. Ayyakkannu Manivannan, for their support and guidance on my research. It's an honor to have them in my committee.

Special thanks are due to all the members of Dr. Bruce Kang's research group in WVU, especially Dr. Gulfam Iqbal. I also appreciate the help from colleagues in WVU NIFT and NETL fuel cell group.

This work is conducted under US DOE (Department of Energy) EPSCoR Program. It is jointly sponsored by US DOE Office of Basic Energy Sciences, NETL (National Energy Technology Laboratory), WV State EPSCoR Office and the West Virginia University under grant number DE-FG02-06ER46299. Dr. Tim Fitzsimmons is the DOE Technical Monitor. Dr. R. Bajura is the Administrative Manager and Dr. I. Celik is the Technical Manager and the Principal Investigator of this project. 


\section{Table of Contents}

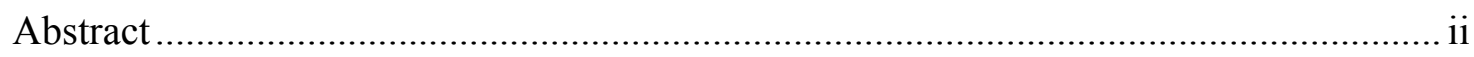

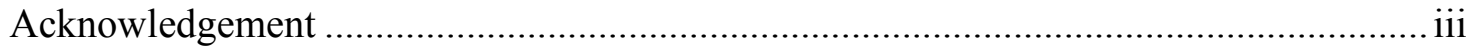

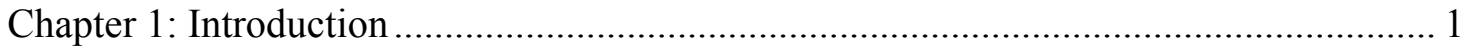

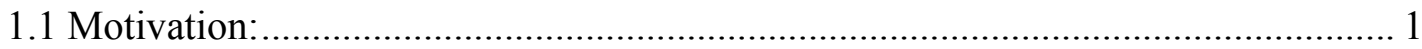

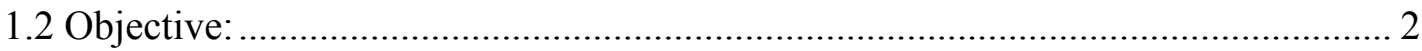

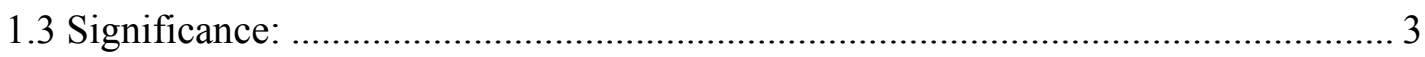

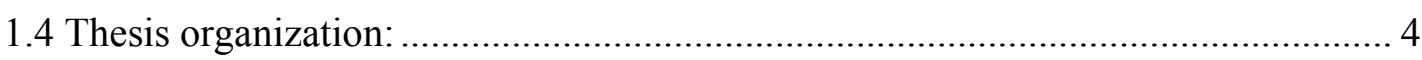

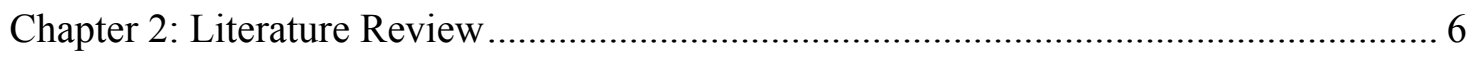

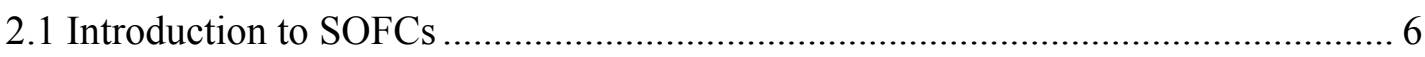

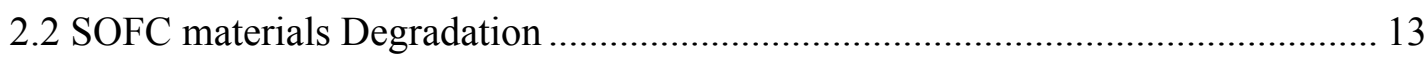

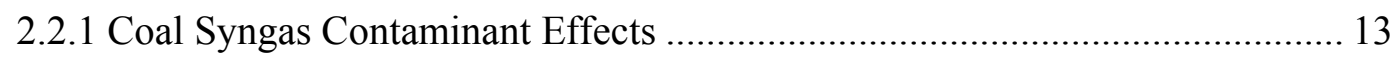

2.2.2 Thermo-Mechanical Effects on SOFC Structure .......................................... 21

2.2.3 Redox Cycle Effects on Anode Mechanical Properties .................................. 24

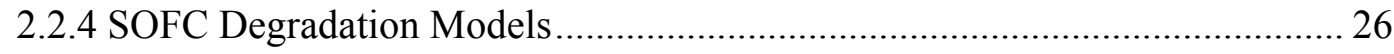

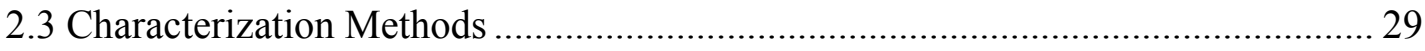

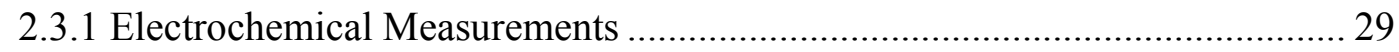

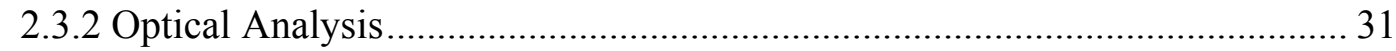

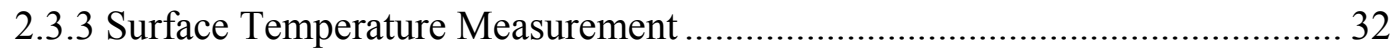

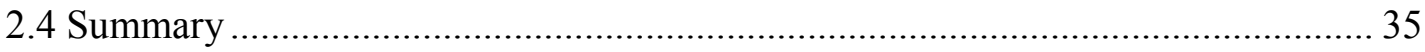

Chapter 3: In-situ Testing Technique Development ......................................................... 36

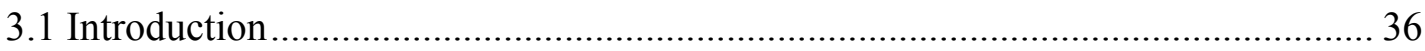

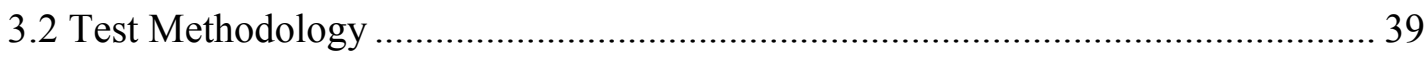

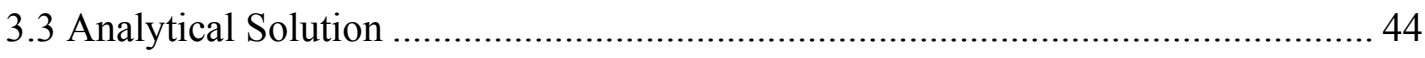

3.4 Surface Deformation Measurements................................................................. 47

3.5 Surface IR Emission Measurements ..................................................................... 51

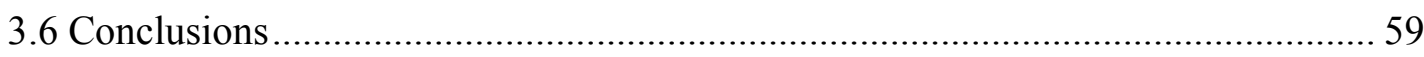

Chapter 4: Characterization of $\mathrm{PH}_{3}$ Poisoning Effects on Ni-YSZ anode........................ 60 


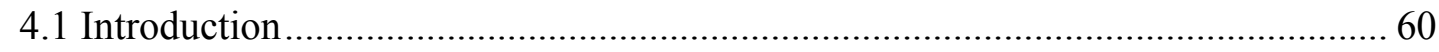

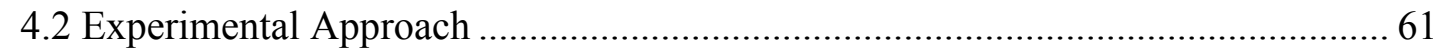

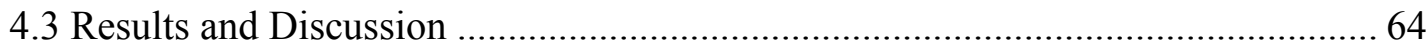

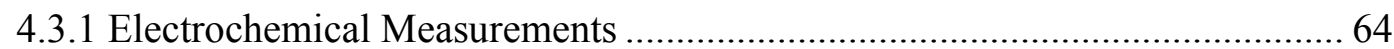

4.3.2 Surface IR Temperature Measurements..................................................... 74

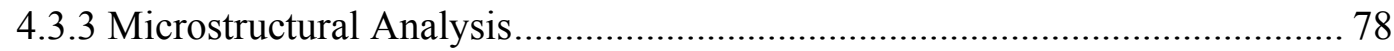

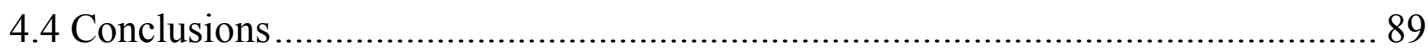

Chapter 5: Conclusions and Future Work...................................................................... 91

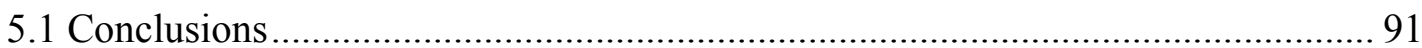

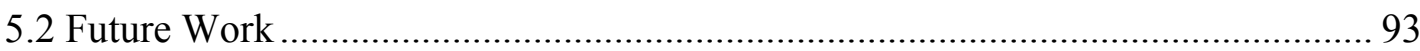

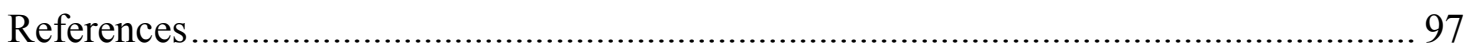

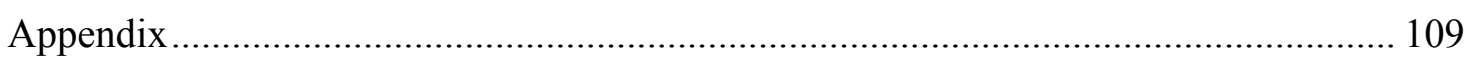




\section{LIST OF FIGURES}

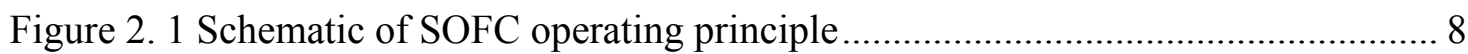

Figure 2. 2 Electrolyte conductivity as a function of operating temperature.................... 11

Figure 2. 3 Schematic of typical anode/electrolyte three-phase boundary ....................... 12

Figure 2. 4 Microstructure degradation of Ni-YSZ after $1000 \mathrm{hr}$ test at $700{ }^{\circ} \mathrm{C}$ with $5 \mathrm{ppm}$

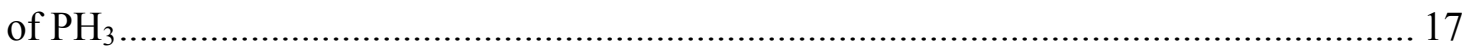

Figure 2. 5 Performance of SOFC with $10 \mathrm{ppm} \mathrm{As(g)} \mathrm{vapor} \mathrm{at} 750^{\circ} \mathrm{C}$ after $60 \mathrm{hrs} . . \ldots . . .18$ Figure 2. 6 Delaminating of Ni mesh from anode surface due to $10 \mathrm{ppm}$ As contaminant

Figure 2. 7 Upper limit of tetragonal phase in $\mathrm{ZrO}_{2}-\mathrm{Y}_{2} \mathrm{O}_{3}$ system as function of aging time $t(\mathrm{~h})$ at $1000^{\circ} \mathrm{C}$.

Figure 2. 8 Curvature recorded before and after $50-\mathrm{hr}$ stress relaxation test at $800^{\circ} \mathrm{C}$ at an initial elastic stress of $45 \mathrm{MPa}$ for a Ni-YSZ test specimen 23

Figure 2. $9 \mathrm{NiO} / \mathrm{YSZ}$ bulk anode sample sintered at (a) $1200^{\circ} \mathrm{C}$ and (b) $1400^{\circ} \mathrm{C} \ldots \ldots \ldots . . .25$

Figure 2. 10 Two degradation zones within anode thickness ........................................ 27

Figure 2. 11 Ideal and Actual I-V Curve for Fuel Cell ................................................... 30

Figure 2. 12 Characteristics of Blackbody Radiation ..................................................... 33

Figure 2. 13 Temperature-related Emissivity of Materials ............................................ 34

Figure 3. 1 Initial alignment of a Sagnac interferometry ................................................ 37

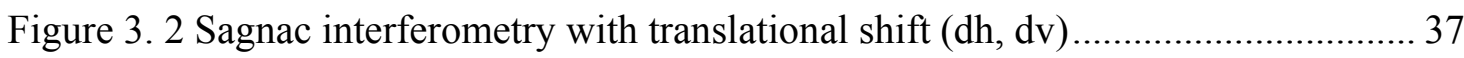

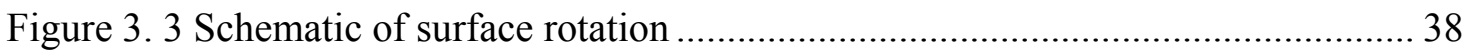

Figure 3. 4 Distribution of strain over a circularly clamped plate under uniform pressure

Figure 3. 5 NexTech Probostate ${ }^{\mathrm{TM}}$ integrated with Sagnac interferometry and IR thermometer.

Figure 3. 6 Integrated IR temperature and out-of-displacement measurement Sagnac interferometry setup

Figure 3. 7 Fuel Gas and Oxidant Supply Pattern 
Figure 3.8 (a) Button cell under uniform pressure with corresponding fringes on a spot location of the Ni wire mesh, (b) button cell surface rotation before and after loading... 43 Figure 3. 9 Button cell modeled as a three-layered thin membrane. 44

Figure 3. 10 (a) Button cell power density plot during pressure changes (b) Effect of cathode side air pressure, (c) Effect of cathode side air flow rate 48

Figure 3. 11 Remedy of Cathode-air Interruption on performance of SOFC with $100 \mathrm{sccm}$ $\mathrm{H}_{2} / 3$ vol. $\% \mathrm{H}_{2} \mathrm{O}$ at $800{ }^{\circ} \mathrm{C}\left(0.5 \mathrm{~A} / \mathrm{cm}^{2}\right)$

Figure 3. 12 Fringe patterns on Ni mesh at $\mathrm{r}=3 \mathrm{~mm}$ from the center with different applied pressures: (a) 0 psi, (b) 7 psi and (c) 13 psi

Figure 3.13 (a) Au strip image on a SOFC button cell and Fringe patterns at $r=5.5 \mathrm{~mm}$ from the center using NexTech Probostat ${ }^{\mathrm{TM}}$ test apparatus with different applied pressures: (b) 0 psi and (c) $19 \mathrm{psi}$ at RT, (d) $5 \mathrm{psi}$ and (e) $15 \mathrm{psi}$ at $800{ }^{\circ} \mathrm{C}$. 50

Figure 3. 14 Steady-state IR Emission Calibration Based on a Thermocouple Measurement

Figure 3. 15 (a) Transient surface IR Emission and (b) Power densities measurement during switch from $100 \mathrm{sccm} \mathrm{H}_{2} / 3$ vol. $\% \mathrm{H}_{2} \mathrm{O}$ to clean syngas at $\mathrm{i}=0.5 \mathrm{~A} / \mathrm{cm}^{2}$ 53 Figure 3. 16 (a) Transient Surface IR Emission Variations of Button Cell at Different Loading Current Densities under $100 \mathrm{sccm} \mathrm{H}_{2} / 3$ vol.\% $\mathrm{H}_{2} \mathrm{O}$; (b) Transient Surface IR Emission Variations at Different Loading Current Densities Interval under $100 \mathrm{sccm} \mathrm{H}_{2} / 3$ vol. $\% \mathrm{H}_{2} \mathrm{O}$, and Corresponding Power Densities History of Button Cell (Surface temperature $\mathrm{T}=799.65{ }^{\circ} \mathrm{C}$ at $\mathrm{i}=0 \mathrm{~A} / \mathrm{cm}^{2}$ ) 55

Figure 3. 17 (a) Transient Surface IR Emission Variations of Button Cell at Different Loading Current Densities under 100 sccm clean syngas; (b) Transient Surface IR Emission Variations at Different Loading Current Densities Interval under $100 \mathrm{sccm}$ clean syngas, and Corresponding Power Densities History of Button Cell (Surface temperature $\mathrm{T}=800.56{ }^{\circ} \mathrm{C}$ at $\mathrm{i}=0 \mathrm{~A} / \mathrm{cm}^{2}$ )

Figure 3.18 (a) Surface IR emission comparisons between $100 \mathrm{sccm} \mathrm{H}_{2} / 3$ vol.\% $\mathrm{H}_{2} \mathrm{O}$ and simulated coal syngas at different loading current densities, (b) Corresponding polarization curves of SOFC 
Figure 3. 19 Surface IR emission comparisons between $100 \mathrm{sccm} \mathrm{H}_{2}$ w/o 3 vol. $\% \mathrm{H}_{2} \mathrm{O}$ at

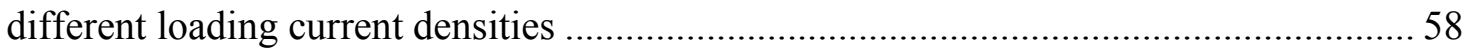

Figure 4. 1 Procedures of SOFC Button Cell Treatment and IR Calibration .................... 62

Figure 4. 2 Procedures of Applying Current Densities .................................................... 63

Figure 4. 3 Variation of SOFC power density under different testing conditions at $i=0.7$

$\mathrm{A} / \mathrm{cm}^{2}$ 65

Figure 4. 4 Corresponding impedance plots for SOFC operating under the open circuit voltage condition (OCV) at $800{ }^{\circ} \mathrm{C}$ 66

Figure 4. 5 Corresponding I-V curves of SOFC operating at $800{ }^{\circ} \mathrm{C}$ 67

Figure 4. 6 Variation of SOFC power density under dry $\mathrm{PH}_{3}$ contained Hydrogen at $\mathrm{i}=$ $0.6 \mathrm{~A} / \mathrm{cm}^{2}$ 68

Figure 4. 7 Corresponding Impedance plots for SOFC operating ....................................69 69

Figure 4. 8 Corresponding I-V curves of SOFC operating at $800{ }^{\circ} \mathrm{C}$..............................6 69

Figure 4. 9 Equivalent circuit models of the impedance spectra .................................. 70

Figure 4. 10 Variation of SOFC Power Density under different testing conditions ......... 72

Figure 4. 11 Corresponding Impedance plots for SOFC operating …............................. 73

Figure 4. 12 Corresponding I-V curves of SOFC operating at $800{ }^{\circ} \mathrm{C} \ldots \ldots \ldots \ldots \ldots \ldots \ldots \ldots \ldots . . . . . . . . . . . . . .73$

Figure 4. 13 Surface temperature comparisons in dry Hydrogen containing $\mathrm{PH}_{3} \ldots \ldots \ldots \ldots .74$

Figure 4. 14 Surface temperature comparisons in $\mathrm{PH}_{3}$ contained Hydrogen w/o steam .. 75 Figure 4. 15 Surface IR Temperature Variation under different testing conditions ......... 76 Figure 4. 16 XRD patterns of the Ni-YSZ electrode: (a) the electrode under Au mesh after exposure to $10 \mathrm{ppm} \mathrm{PH}_{3}$ in dry $\mathrm{H}_{2}$ for $300 \mathrm{hrs}$; (b) the electrode under Au mesh after exposure to 10 ppm $\mathrm{PH}_{3}$ in $\mathrm{H}_{2} / 3$ vol.\% $\mathrm{H}_{2} \mathrm{O}$ for $200 \mathrm{hrs}$; (c) the electrode open

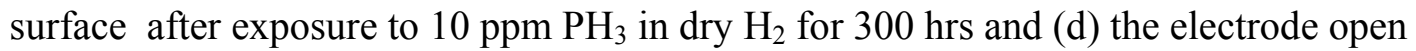
surface after exposure to $10 \mathrm{ppm} \mathrm{PH}_{3}$ in $\mathrm{H}_{2} / 3$ vol.\% $\mathrm{H}_{2} \mathrm{O}$ for $200 \mathrm{hrs}$ at $\mathrm{i}=0.6 \mathrm{~A} / \mathrm{cm}^{2}$.. 79 Figure 4. 17 SEM Micrograph of the Ni-YSZ anode surface after exposure to $10 \mathrm{ppm}$ $\mathrm{PH}_{3}$ in (a) $\mathrm{H}_{2} / 3$ vol.\% $\mathrm{H}_{2} \mathrm{O}$ for $200 \mathrm{hrs}$ and (b) dry $\mathrm{H}_{2}$ for $300 \mathrm{hrs}$ at $\mathrm{i}=0.6 \mathrm{~A} / \mathrm{cm}^{2}$ .81 Figure 4. 18 SEM Micrograph of the Ni-YSZ anode cross-section after exposure to 10 ppm $\mathrm{PH}_{3}$ in (a) $\mathrm{H}_{2} / 3$ vol. $\% \mathrm{H}_{2} \mathrm{O}$ for $200 \mathrm{hrs}$ and (b) dry $\mathrm{H}_{2}$ for $300 \mathrm{hrs}$ at $\mathrm{i}=0.6 \mathrm{~A} / \mathrm{cm}^{2} 82$ 
Figure 4. 19 XPS spectra of the Ni-YSZ anode after exposure to $10 \mathrm{ppm} \mathrm{PH}_{3}$ in $\mathrm{H}_{2} / 3$ vol. $\% \mathrm{H}_{2} \mathrm{O}$ for $200 \mathrm{hrs}$ at $\mathrm{i}=0.6 \mathrm{~A} / \mathrm{cm}^{2}$ : (a) open surface and (b) cross section 83

Figure 4. 20 Phase diagram for the equilibrium concentrations of $\mathrm{PH}_{3}$ and $\mathrm{P}_{2} \mathrm{O}_{3}$ as a function of the initial $\mathrm{PH}_{3}$ concentration 84

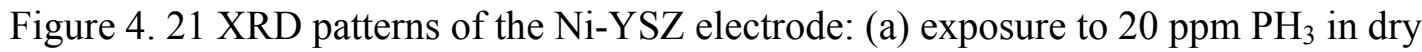
$\mathrm{H}_{2}$ for $100 \mathrm{hrs}$ at $\mathrm{OCV}$; (b) exposure to $20 \mathrm{ppm} \mathrm{PH}_{3}$ in $\mathrm{H}_{2} / 26$ vol.\% $\mathrm{H}_{2} \mathrm{O}$ for $100 \mathrm{hrs}$ at $\mathrm{OCV}$; (c) exposure to $20 \mathrm{ppm} \mathrm{PH}_{3}$ in dry $\mathrm{H}_{2}$ for $100 \mathrm{hrs}$ at $0.3 \mathrm{~V}$ of potential bias; (d) $\mathrm{Au}$ mesh with Ni paste on electrode surface after exposure to $10 \mathrm{ppm} \mathrm{PH}_{3}$ in $\mathrm{H}_{2}$ with 3-6 vol. $\% \mathrm{H}_{2} \mathrm{O}$ for $100 \mathrm{hrs}$ at $0.3 \mathrm{~V}$ of potential bias and (e) the electrode under $\mathrm{Au}$ mesh

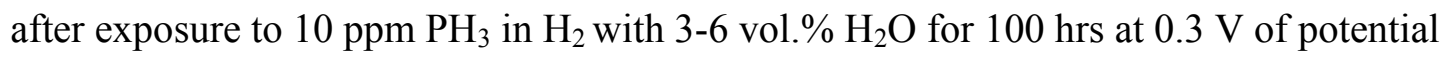
bias

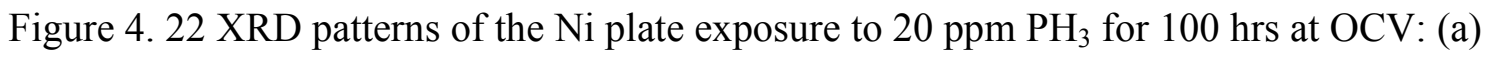
in dry $\mathrm{H}_{2}$ and (b) in $\mathrm{H}_{2} / 26$ vol. $\% \mathrm{H}_{2} \mathrm{O}$ 86

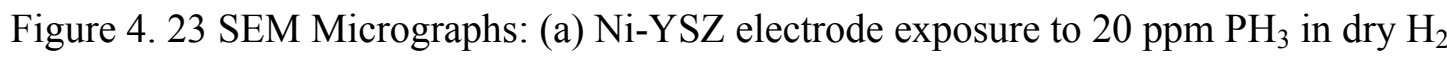
for $100 \mathrm{hrs}$ at OCV; (b) Ni-YSZ electrode exposure to 20 ppm $\mathrm{PH}_{3}$ in $\mathrm{H}_{2} / 26$ vol.\% $\mathrm{H}_{2} \mathrm{O}$

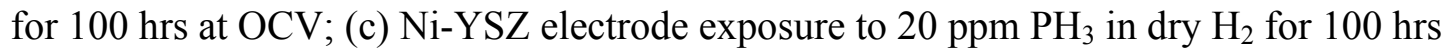
at $0.3 \mathrm{~V}$ of potential bias; (d) Au mesh with Ni paste on Ni-YSZ electrode surface after exposure to 10 ppm $\mathrm{PH}_{3}$ in $\mathrm{H}_{2}$ with 3-6 vol. $\% \mathrm{H}_{2} \mathrm{O}$ for $100 \mathrm{hrs}$ at $0.3 \mathrm{~V}$ of potential bias,

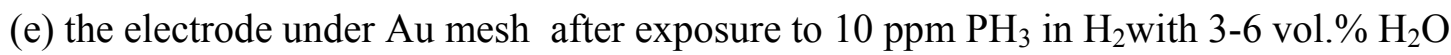
for $100 \mathrm{hrs}$ at $0.3 \mathrm{~V}$ of potential bias and (f) Ni plate exposure to $20 \mathrm{ppm} \mathrm{PH}_{3}$ in $\mathrm{H}_{2} / 26$ vol. $\% \mathrm{H}_{2} \mathrm{O}$ for $100 \mathrm{hrs}$ at $\mathrm{OCV}$ 88

Figure 5. 1 NexTech Probostate ${ }^{\mathrm{TM}}$ integrated with Sagnac interferometry FTIR Emission Spectroscopy and IR thermometer. .93

Figure 5. 2 Determining of the initial degradation threshold. 95

Figure 5. 3 Initiation of degradation at critical pressure Pc 95 


\section{LIST OF TABLES}

Table 2. 1 Technical characteristics of the major fuel cells............................................. 7

Table 2. 2 Trace species and concentration in coal syngas........................................... 15

Table 2. 3 Status of trace contaminants in coal syngas................................................... 15

Table 2. 4 Percentage length change $\Delta l / l_{o}$ of $\mathrm{NiO} / \mathrm{YSZ}$ sintered at different temperature

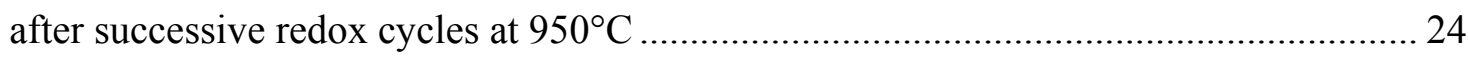

Table 3. 1 Numerical and Analytical results of out of plane deformation a button cell under uniform pressure

Table 3. 2 Comparison among experimental, FE simulating and analytical prediction ... 51

Table 4. 1 Results of fitting EIS at the different conditions .71 


\section{Chapter 1: Introduction}

\subsection{Motivation:}

Solid Oxide Fuel Cell (SOFC) is an attractive source of energy production given its ability to operate quietly, cleanly and with high fuel-to-electricity conversion efficiency of up to $70 \%$. Due to its high operating temperature $\left(>700{ }^{\circ} \mathrm{C}\right)$ and tolerance for fuel contaminates compared to other types of fuel cells, in principal, SOFC can utilize all kinds of combustion fuels, such as hydrogen [1, 2], natural gas [3], oil [4], biogas [5], even coal derived syngas [6-8]. Potentially, it is an efficient technology to directly utilize coal syngas (produced from coal via gasification) for the future generation clean power generation, when coal-derived fuels will continue to play a significant role in the energy resources utilized in the United States of America, SOFC technology will be the focus of attention.

However, SOFC operation with coal syngas has shown some challenges. Coal syngas fed into SOFCs from coal via gasification contains various contaminants including P, As, Zn, S, Hg, Se, and so on [6-17]. The cost is too high to completely clean up such contaminants, whereas SOFC anodes are susceptible to these coal syngas contaminants, which can cause both electrochemical and anode material degradation [17]. The SOFC anodes are also subjected to stresses at high temperature, thermal/redox cycles effects during long-term operation and thus are required to maintain the material integrity to prevent mechanical failure for an extended period of time $(40000 \mathrm{hrs})$. These degradation mechanisms cause changes of SOFC material microstructure and degrade its electrochemical and structural properties [18-30].

At present, considerable research efforts are focused on the studies of SOFC electrochemical performance to understand the mechanisms responsible for fuel 
oxidation and power production. However, little is known about molecular processes that occur during the operation of SOFC under coal syngas with the presence of trace amount of contaminants, and the correlation to SOFC material structural integrity, due to the lack of suitable experimental methods that are capable of probing directly the chemical transformations and structural changes in SOFCs. In order to determine the degradation mechanisms, a powerful in-situ test technique that can provide structural and electrochemical details under conditions of actual fuel cell operation is extremely attractive and necessary.

\subsection{Objective:}

The overall objective of this study is to characterize electrochemical and structural degradations of SOFC anode materials due to fuel contaminant and thermo-mechanical effects, using both in-situ and post-term analyzing methods.

The first specific aim is to develop a technology which enables in-situ investigation of the SOFC electrochemical reactions and electrode structure durability under realistic operation with coal syngas. The research effort will be focused on the optical methods. A standard SOFC button cell test apparatus will be integrated with Saganac interferometry optical technique and infrared thermometer. The surface out-of-plane deformation and IR emission will be carried out under service conditions. The correlation between electrode structural parameters and surface deformation will be demonstrated whereas the estimated material parameters will be used for a SOFC anode material durability model, which incorporates thermo-mechanical and fuel gas contaminants degradation mechanisms, to predict long-term structural integrity of SOFC anode.

The second specific aim is to gain fundamental understanding of the degradation mechanism of SOFC anode materials operating in the phosphorus-containing fuel gas via the in-situ technique developed in the first part of work, as well as other common 
methods, such as electrochemical measurement, material characterization and thermodynamics calculations. The poisoning effects of phosphine $\left(\mathrm{PH}_{3}\right)$ will be investigated on the Ni-YSZ anode electrochemical performance and structural properties under different operating conditions, such as with/without steam and electrical bias. The interrelationship among the surface IR emission, the electrochemical performance and the microstructure of electrode will be presented.

\subsection{Significance:}

Direct utilization of coal syngas in SOFCs is limited due to the deleterious effects of contaminants in coal syngas. Currently, most of research efforts are focused on its electrochemical performance degradation. The structural degradation is not given much attention. However, the mechanical integrity of the fuel cell anode under service conditions is also essential for successful long-term operation. Our in-situ technique can provide electrochemical performance measurement and the information on the structural variation details under the SOFC operating conditions. In this dissertation, the degradation behavior and the fundamental mechanism will be investigated, while the corresponding material parameters will be estimated. The proposed research will provide researchers and industry with the data that would be useful for validation and development of SOFC electrochemical and structural durability models, which is prerequisite for formulating a solution to the coal syngas contaminant problem.

In addition, our unique design of optical technique is not limited in the application of SOFCs. This technique has high measurement sensitivity (half wavelength) and is immune to the system vibration and temperature fluctuations. It can provide in-situ, noncontact and nondestructive surface analysis as a temperature sensor or as digital image for stress analysis. Potentially, it can also be integrated with the FTIR spectroscopy, which can be utilized for surface species and reaction investigation. 


\subsection{Thesis organization:}

This dissertation consists of 5 chapters including the Introduction.

In Chapter 2, a detail literature review of the investigated degradation behavior of Ni-YSZ anode operating in coal syngas with the trace contaminants will be given. The degradation mechanism, including electrochemical and structural degradation, is discussed. Based on this review, a SOFC anode material durability model developed in our group to predict long-term structural integrity of SOFC anode material is provided. The efforts of SOFC characterization methods to investigate the electrode reaction and estimate the material parameters are emphasized. An improvement of in-situ test technique and characterization method then becomes attractive and required in order to validate and develop the SOFC numerical models.

In Chapter 3, the principle of Sagnac interferometry is presented, and an in-situ, non-contact optical technique is developed and utilized to investigate the electrode material properties along with the SOFC electrochemical performance. A standard SOFC button cell test apparatus will be integrated with Saganac interferometry optical technique and infrared thermometer for the electrode surface deformation and temperature measurements, respectively. The measurements were carried out under SOFC service conditions, and the experimental data were applied to validate and develop the SOFC numerical models, including electrochemical and structural simulations.

In Chapter 4, the developed in-situ technique is utilized to study the poisoning effect of $\mathrm{PH}_{3}$ contaminant on SOFC performance. Several main factors which are essential to the degradation behavior are investigated, such as concentration of $\mathrm{PH}_{3}$ contaminant and steam as well as the cell operation conditions. The SOFC electrochemical performance degradation and electrode surface IR emission are studied as well as the change of electrode material structure. A detail survey of Ni-YSZ anode degradation behavior in 
$\mathrm{PH}_{3}$ contaminant-containing hydrogen is given, and the corresponding degradation mechanism is discussed.

In Chapter 5, the main findings of this study are summarized, and the outlook of future research is given. 


\section{Chapter 2: Literature Review}

\subsection{Introduction to SOFCs}

Fuel cells are electrochemical devices that convert chemical energy of fuels into electrical work directly, promising power generation with higher conversion efficiency and lower environmental impact rather than conventional routines of power generation [31-38].The technical characteristics of the major fuel cells are listed and compared in Table 2.1. Different from other fuel cell technologies, solid oxide fuel cells (SOFCs) have emerged as a serious high temperature fuel cell technology $\left(600-1000{ }^{\circ} \mathrm{C}\right)$. The relatively high operating temperature allows for internal reforming, rapid electro-catalysis with non-precious metals, and highly efficient conversion to power (up to 70-80\%), greater fuel gas flexibility and high quality by-product heat for cogeneration or for use in a bottoming cycle. Indeed, both simple-cycle and SOFC/gas turbine hybrid systems have been demonstrated recently. The other advantage is that SOFCs are composed of allsolid-state materials. Without liquid electrolyte and the attendant material corrosion or electrolyte management problems, SOFC has no fundamental restriction on the cell configuration and it is easy and quiet enough to be installed or handled during the operation $[38,39]$. These capabilities, combined with its high power densities $\left(1 \mathrm{~W} / \mathrm{cm}^{2}\right.$ to $3 \mathrm{~W} / \mathrm{cm}^{2}$ for normal single cell [40]) and less-expensive materials, have made SOFC an attractive emerging technology for high-power application such from power plant station to APU (auxiliary power unit).

An individual SOFC cell consists of porous anode (or fuel electrode) and cathode (or air electrode) sandwiched around a solid, non-porous ceramic electrolyte. Unit cells can be constructed in two main configurations, i.e., tubular and planar cells. To produce significant amount of power, practical SOFC units are assembled into a stack with electrical interconnects, which is used to link individual cells together in series or parallel to build a desired output voltage. 
Table 2. 1 Technical characteristics of the major fuel cells (reprinted from Ref 31 and 38)

\begin{tabular}{|c|c|c|c|c|c|c|}
\hline $\begin{array}{c}\text { Types of fuel } \\
\text { cell }\end{array}$ & $\begin{array}{l}\text { Operating } \\
\text { temperature }\end{array}$ & Electrolyte & Fuel & $\begin{array}{c}\text { Efficiency } \\
(\%)\end{array}$ & $\begin{array}{c}\text { Power density } \\
\left(\mathrm{mW} / \mathrm{cm}^{2}\right)\end{array}$ & $\begin{array}{c}\text { Power range } \\
(\mathrm{kW})\end{array}$ \\
\hline $\begin{array}{c}\text { PAFC } \\
\text { (Phosphoric acid } \\
\text { fuel cell) }\end{array}$ & $160-210^{\circ} \mathrm{C}$ & Phosphoric acid & $\begin{array}{c}\text { Hydrogen from } \\
\text { hydrocarbons and } \\
\text { alcohol }\end{array}$ & 40 & $150-300$ & $50-1000$ \\
\hline $\begin{array}{c}\text { PEMFC } \\
\text { (Polymer } \\
\text { exchange } \\
\text { membrane fuel } \\
\text { cell) }\end{array}$ & $50-80{ }^{\circ} \mathrm{C}$ & $\begin{array}{c}\text { Polymer, proton } \\
\text { exchange membrane }\end{array}$ & $\begin{array}{l}\text { Less pure hydrogen } \\
\text { from hydrocarbons or } \\
\text { methanol }\end{array}$ & $40-50$ & $300-1000$ & $\begin{array}{c}0.0001- \\
1000\end{array}$ \\
\hline $\begin{array}{l}\text { AFC (Alkaline } \\
\text { fuel cell) }\end{array}$ & $50-200{ }^{\circ} \mathrm{C}$ & $\begin{array}{l}\text { Potassium hydroxide } \\
(\mathrm{KOH})\end{array}$ & $\begin{array}{l}\text { Pure hydrogen, or } \\
\text { hydrazine }\end{array}$ & 50 & $150-400$ & $1-100$ \\
\hline $\begin{array}{l}\text { MCFC (Molten } \\
\text { carbonate fuel } \\
\text { cell) }\end{array}$ & $630-650{ }^{\circ} \mathrm{C}$ & $\begin{array}{l}\text { Molten salt, such as } \\
\text { nitrate, sulphate, } \\
\text { carbonates, ... }\end{array}$ & $\begin{array}{c}\text { Hydrogen, carbon } \\
\text { monoxide, natural gas, } \\
\text { propane, marine diesel }\end{array}$ & $45-55$ & $100-300$ & $\begin{array}{c}100- \\
100,000\end{array}$ \\
\hline $\begin{array}{c}\text { SOFC (Solid } \\
\text { oxide fuel cell) }\end{array}$ & $600-1000^{\circ} \mathrm{C}$ & $\begin{array}{l}\text { Ceramic, such as } \\
\text { stabilized zirconia } \\
\text { and doped } \\
\text { perovskite }\end{array}$ & $\begin{array}{c}\text { Hydrogen, natural gas, } \\
\text { biogas, coal derived } \\
\text { syngas }\end{array}$ & $\begin{array}{c}70-80 \\
\text { (integrated } \\
\text { with gas } \\
\text { turbine) }\end{array}$ & Up to 1000 & $10-100,000$ \\
\hline
\end{tabular}




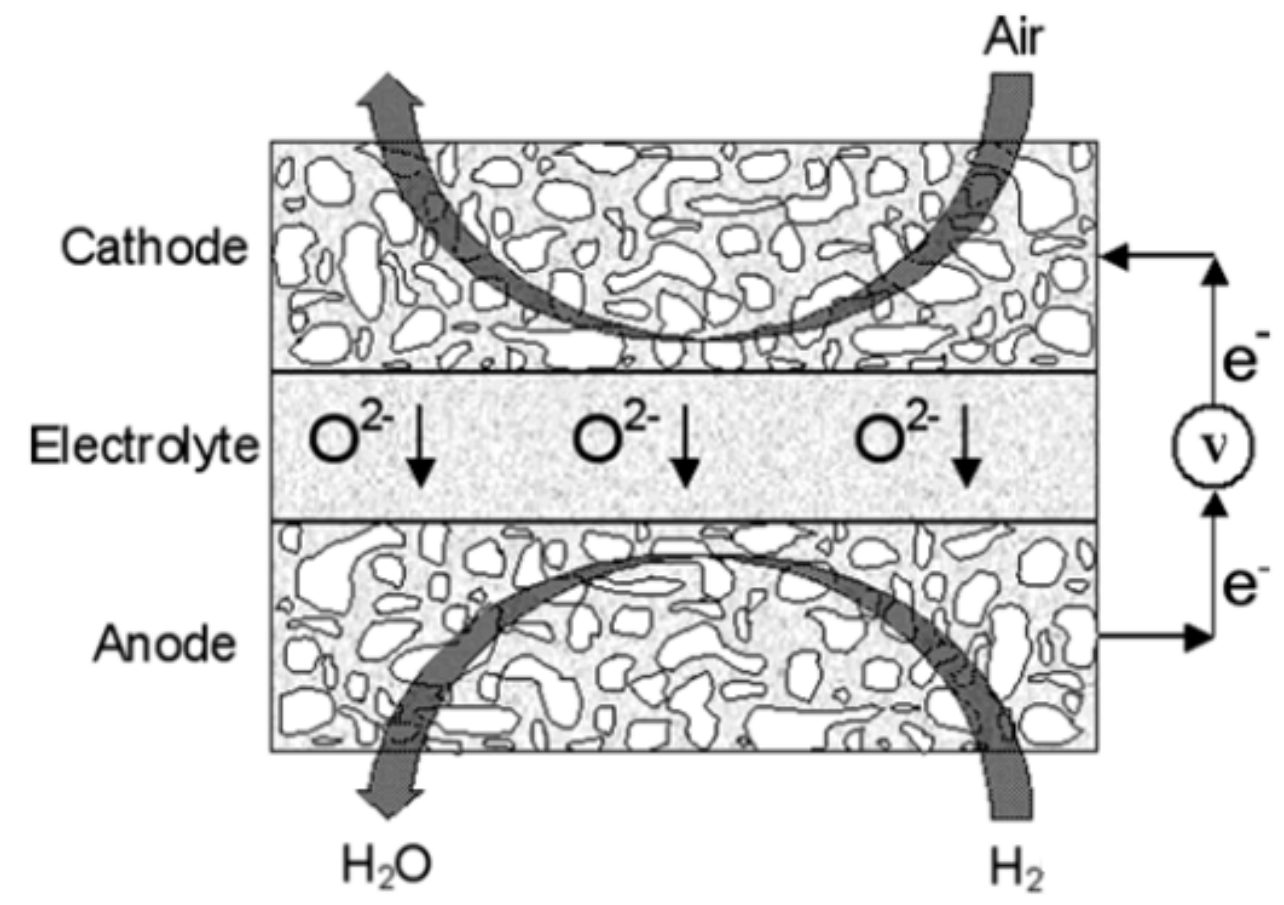

Figure 2. 1 Schematic of SOFC operating principle (redrawn from Ref 34)

Under operation, oxygen molecule, from the air, enters the cell through the cathode of the fuel cell and fuel gas, such as hydrogen, is fed into the anode. On the anode side, the oxygen ions encounter the fuel at the anode/electrolyte interface and react catalytically, releasing electrons $\left(\mathrm{e}^{-}\right)$. On the other side, cathode side, an oxygen concentration gradient is created across the electrolyte, which attracts oxygen ions from cathode to anode. Through the external circuit, the electrons will transport from the anode to the cathode, where a continuous supply of oxygen ions $\left(\mathrm{O}^{2-}\right)$ for the electrolyte is maintained, and oxygen ions from cathode to anode, maintaining overall electrical charge balance, thereby generating useful electrical power from the combustion of the fuel. The only byproduct of this process is a pure water molecule $\left(\mathrm{H}_{2} \mathrm{O}\right)$ and heat. A schematic representation of a unit cell based on ionic oxygen conductors is shown in Figure 2.1. The SOFC reactions include: 
Anode side:

Cathode side:

$$
\mathrm{H}_{2}+\mathrm{O}^{2-} \rightarrow \mathrm{H}_{2} \mathrm{O}+2 e^{-}
$$

The overall reaction is

$$
1 / 2 \mathrm{O}_{2}+2 e^{-} \rightarrow \mathrm{O}^{2-}
$$

$$
\mathrm{H}_{2}+1 / 2 \mathrm{O}_{2} \rightarrow \mathrm{H}_{2} \mathrm{O}
$$

The maximum electrical energy available from the fuel cell is determined by the Gibbs free energy difference, $\Delta G$, across the electrolyte membrane at a given temperature. The equilibrium potential of the cell is determined through the Nernst equation:

$$
E=E_{0}+\frac{R T}{2 F} \ln \frac{a H_{2} a O_{2}^{1 / 2}}{a H_{2} O}
$$

Here, $\mathrm{E}_{0}$ is the standard potential, for $-\Delta G / 2 \mathrm{~F}, \mathrm{R}$ is the gas constant, $\mathrm{T}$ is the temperature in $\mathrm{K}, \mathrm{F}$ is the Faraday constant, and a is the chemical activity for the relevant species. Internal reforming of natural gas or other hydrocarbon fuels within SOFC is allowed to extract the necessary hydrogen. Similar relationships can be written to calculate the equilibrium potentials for other fuels. For various fuels, the standard cell potential is around $1 \mathrm{~V}$ at operating temperature $\left(>700{ }^{\circ} \mathrm{C}\right)$.

Anode, cathode and electrolyte of the SOFC each serve several functions. Therefore certain requirements are necessary, especially during the long-term operation, such as [38]:

- Proper stability (chemical, phase, morphological, and dimensional)

- Chemical compatibility with other components

- Similar thermal expansion to avoid cracking during the cell operation

- Proper conductivity

- Dense electrolyte to prevent gas mixing

- Porous electrodes to allow gas transport to the reaction sites

- Amenable to particular fabrication conditions

- Low cost 
The distinguishing feature of SOFCs is that the electrolyte is a solid non-porous ionconducting ceramic and an electronic insulator. It must be dense to separate the fuel and air compartment of the cell and prevent the two electrodes to come into electronic contact by blocking the electrons, whereas retaining its high ion conductivity to maintain the overall electrical charge balance, which determines the operating temperature of SOFC. Currently, the most common electrolyte for SOFC has been yttrium stabilized zirconia (YSZ), in which a tiny amount of yttria $(3,8$, or 10 percent) is added to stabilize the crystal structure of zircon to be cubic [39]. The operating temperature is set by the requirement for its high ionic conductivity, greater than $700{ }^{\circ} \mathrm{C}$.

Alternative electrolytes with higher ionic conductivities at lower temperatures, such as gadolinium-doped ceria (GDC), samarium-doped ceria (SDC), scandium-doped zirconia (SDZ), have been considered and are being developed. As shown in Figure 2.2, ceria based electrolyte is more conductive than YSZ, permitting a further reduction of the operating temperature by $50-100{ }^{\circ} \mathrm{C}$. However, most of these materials do not have the same high stability and low electronic conductivity, especially under low oxygen pressure $[34,42]$. Another trend to improve the cell performance and decrease operating temperature, simplifying the materials requirements in other parts of the SOFC, is to produce thin-film ( 10 um) electrolyte membrane on porous electrode structures $[72,73]$.

Anode materials must be catalytically active and stable for the oxidation/reduction and retain sufficient electronic and ionic conductivities. Its structure is fabricated with high porosity and high surface area to promote the gas mass transport and catalysis reactions. For the more recent anode-supported cells, it also requires good mechanical properties and geometric stability during manufacture and operation. The most common anode material is a cermet of $\mathrm{Ni}$ and YSZ. Ni provides the catalytic activity and electronic conductivity, while the YSZ component serves to inhibit the sintering of the metal particles and provide ionic conductivity and a thermal expansion match with the YSZ electrolyte [34, 39]. 


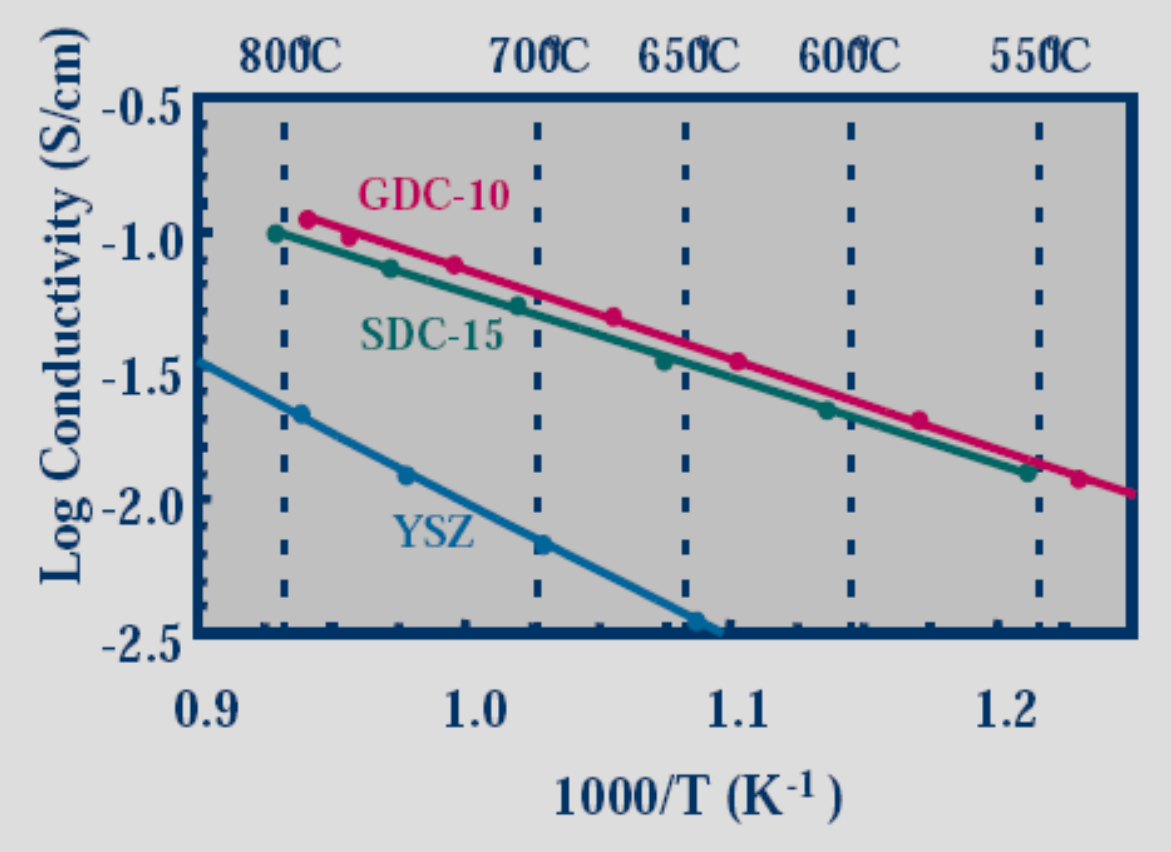

Figure 2. 2 Electrolyte conductivity as a function of operating temperature [Ref 41]

As illustrated in Figure 2.3, the electrochemical reaction can only occur at the threephase boundary (TPB), at which the electrolyte, the electron-conducting metal phase, and the gas phase all come together. Since the electrode structure and composition clearly affect the size of the TPB, the performance of an SOFC depends strongly on the anode microstructure [34]. The composition, powder sizes, and the manufacturing method are key to achieving the desired structure. For example, reduction of $\mathrm{NiO}$ powder in the virgin anode mixture provides desired porosity, while a combination of coarse and fine YSZ powder achieves the desired mechanical strength and contact between the Ni and YSZ phases.

Currently, most cathodes are based on lanthanum-based perovskite-type ceramics (structure $\mathrm{ABO}_{3}$ ), such as $\mathrm{LaSrMnO}_{3}$ (LSM) [40], (La, Sr)(Fe)O 3 (LSF) [43], (La, Sr)(Co, $\mathrm{Fe}) \mathrm{O}_{3}$ (LSCF) [44], $\mathrm{LaCaMnO}_{3}$ (LCM) [45]. LSM and LCM provide good compatibility 
with YSZ and the high electro-catalytic activity at operating temperature above $800{ }^{\circ} \mathrm{C}$. For intermediate-temperature application $\left(700-800{ }^{\circ} \mathrm{C}\right)$, a composite layer (typically 20 40 um thick) of YSZ and LSM is often used to overcome the modest ion conductivity [46]. Alternatively, LSCF or LSF are also pursued as cathode of intermediatetemperature SOFC.

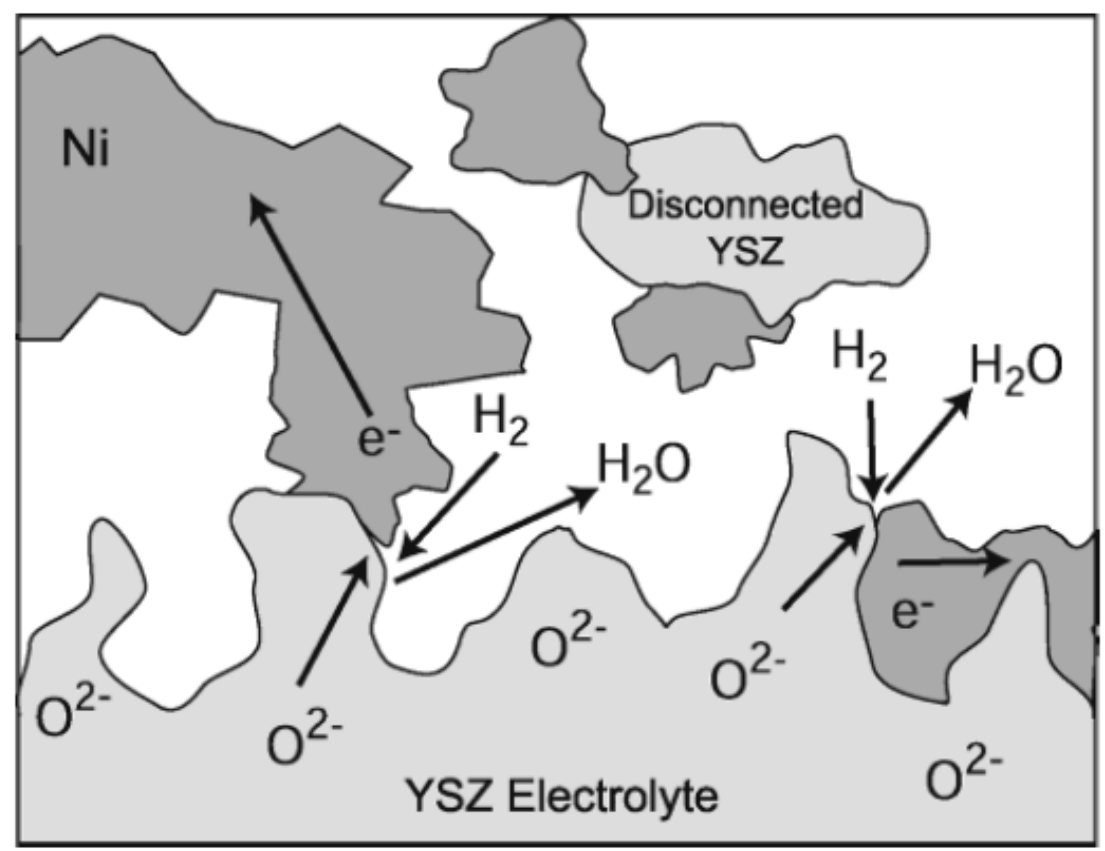

Figure 2. 3 Schematic of typical anode/electrolyte three-phase boundary [Ref 34]

Similar to the anode, the electrolyte materials is incorporated into the cathode materials to improve electrode performance at lower temperature due to the volume increase of active sites available for electrochemical reactions, whereas the porous cathode structure permits rapid mass transport of reactant and product gases [38, 41].

In principle, SOFC can operate on any combustion fuel. Internal reforming within SOFC allows extracting hydrogen from nature gas, gasoline, diesel, and other hydrocarbon fuels [34, 47-49]. Different from hydrogen gas, hydrocarbons, for which a supply infrastructure is currently available, are much easier to transport and store because 
of their stable state. In addition, they are more efficient at producing energy. Compared with two electrons energy per molecule for hydrogen, methane can yield eight electrons energy per molecule. These advantages could be magnified with the use of more complex hydrocarbons, or coal-derived gases [7, 8, 50-53].

\subsection{SOFC materials Degradation}

Currently, the direct utilization of coal syngas in high temperature fuel cell has been given most attention. Several studies $[7,8,50-53]$ have shown the feasibility of utilizing coal-derived syngas as fuel for SOFC system. However, harsh operating conditions, such as high temperature, thermal/redox cyclic, and exposure of various contaminants in coal syngas fuel, may deteriorate anode electrochemical performance and materials properties and reduce its service life.

Materials degradation is progressive physical and chemical processes which deteriorate their load carrying capability. Material degradation may occur due to several mechanisms depending on the environment and loading conditions. From a general standpoint, degradation of the material microstructure is due to irreversible phenomena such as formation of different phases, micro cracks, micro voids, and debonding between the constitutive phases particles in a multiphase material.

\subsubsection{Coal Syngas Contaminant Effects}

Coal syngas is derived from coal gasification process that converts the solid coal to the gas phase under the pressure of $24-70$ atm at $500-1800{ }^{\circ} \mathrm{C}[54,55]$. The main coal syngas composition consists of $\mathrm{H}_{2}, \mathrm{CO}, \mathrm{CO}_{2}$, and $\mathrm{H}_{2} \mathrm{O}$ [54], whereas the contaminants existing in the coal are vaporized or gasified as well. To purify coal syngas, cleanup 
techniques have been developed and employed, such as absorption, adsorption, diffusion through a membrane, chemical conversion and filtering, whereas it is successful to remove some of the species like $\mathrm{H}_{2} \mathrm{~S}$, halides and fly ash particles. However, these processes are not cost effective and carried out at lower temperature, and hence a significance portion of syngas thermal energy is lost [13]. In addition, there are no effective ways to remove other trace elements, such as As, P, Zn, etc.

The composition of the coal-derived syngas strongly relies on the coal and the gasification processes. The typical trace contaminants in coal syngas are listed in Table 2.2 by Trembly, etc [13]. It needs to be noted that the same trace contaminant has different chemical status at different temperature and thus the real composition under SOFC operating conditions is still not clear. Due to the thermodynamic equilibrium calculations, a summary of different contaminant chemical forms is indicated in Table 2.3 [11].

Currently, the investigations of the coal syngas contaminant effects on the performance of SOFCs have been given most attention. Most of the present data about the effect of contaminants on the SOFC anode are summarized by F. N. Cayan, et al. [17, 122]. It has been reported that $\mathrm{Hg}, \mathrm{Si}, \mathrm{Zn}$ and $\mathrm{NH}_{3}$ in the coal syngas do not significantly affect the performance of Ni-YSZ anode, while the existence of $\mathrm{Cd}$ and $\mathrm{Se}$ impact the SOFC anode performance to some extent. Contaminants such as $\mathrm{P}, \mathrm{As}, \mathrm{Cl}$ and $\mathrm{Sb}$ have the potential to react with the fuel cell materials and affect their electrochemical and mechanical properties. The effects of specific contaminants are described as following: 
Table 2. 2 Trace species and concentration in coal syngas [Ref 13]

\begin{tabular}{c|c}
\hline Component & Concentration(ppmv) \\
\hline $\mathrm{AsH}_{3}$ & 0.6 \\
$\mathrm{HCl}$ & 1 \\
$\mathrm{PH}_{3}$ & 1.91 \\
$\mathrm{Sb}$ & 0.07 \\
$\mathrm{Cd}$ & 0.011 \\
$\mathrm{Be}$ & 0.025 \\
$\mathrm{Cr}$ & 6 \\
$\mathrm{Hg}$ & 0.025 \\
$\mathrm{~K}$ & 512 \\
$\mathrm{Se}$ & 0.15 \\
$\mathrm{Na}$ & 320 \\
$\mathrm{~V}$ & 0.025 \\
$\mathrm{~Pb}$ & 0.26 \\
$\mathrm{Zn}$ & 9 \\
\hline
\end{tabular}

Table 2. 3 Status of trace contaminants in coal syngas [Ref 11]

\begin{tabular}{|c|c|c|c|c|}
\hline Element & $>1000^{\circ} \mathrm{C}$ & $400-800^{\circ} \mathrm{C}$ & $100-400^{\circ} \mathrm{C}$ & $<100^{\circ} \mathrm{C}$ \\
\hline As & $\mathrm{AsO}, \mathrm{As}_{2}$ & $\mathrm{AsO}, \mathrm{As}_{4}$ & $\mathrm{As}_{2}$ & $\mathrm{AsH}_{3}$ \\
\hline $\mathrm{Be}$ & $\mathrm{Be}(\mathrm{OH})_{2}$ & $\begin{array}{c}\text { Condensed } \\
\text { species }\end{array}$ & $\begin{array}{c}\text { Condensed } \\
\text { species }\end{array}$ & $\begin{array}{c}\text { Condensed } \\
\text { species }\end{array}$ \\
\hline $\mathrm{Hg}$ & $\mathrm{Hg}$ & $\mathrm{Hg}$ & $\mathrm{Hg}, \mathrm{HgCl}_{2}$ & $\mathrm{Hg}, \mathrm{HgCl}_{2}$ \\
\hline B & $\mathrm{HBO}$ & $\mathrm{HBO}$ & $\mathrm{HBO}$ & - \\
\hline V & $\mathrm{VO}_{2}$ & $\begin{array}{c}\text { Condensed } \\
\text { species }\end{array}$ & $\begin{array}{c}\text { Condensed } \\
\text { species }\end{array}$ & $\begin{array}{c}\text { Condensed } \\
\text { species }\end{array}$ \\
\hline $\mathrm{Se}$ & $\mathrm{H}_{2} \mathrm{Se}, \mathrm{Se}, \mathrm{SeO}$ & $\mathrm{H}_{2} \mathrm{Se}$ & $\mathrm{H}_{2} \mathrm{Se}$ & $\mathrm{H}_{2} \mathrm{Se}$ \\
\hline $\mathrm{Ni}$ & $\mathrm{NiCl}, \mathrm{NiCl}_{2}$ & $\begin{array}{c}\text { Condensed } \\
\text { species }\end{array}$ & $\mathrm{Ni}(\mathrm{CO})_{4}$ & $\mathrm{Ni}(\mathrm{CO})_{4}$ \\
\hline Co & $\mathrm{CoCl}_{2}, \mathrm{CoCl}$ & $\begin{array}{c}\text { Condensed } \\
\text { species }\end{array}$ & $\begin{array}{c}\text { Condensed } \\
\text { species }\end{array}$ & $\begin{array}{c}\text { Condensed } \\
\text { species }\end{array}$ \\
\hline $\mathrm{Sb}$ & $\mathrm{SbO}, \mathrm{Sb}_{2}$ & $\mathrm{SbO}, \mathrm{Sb}_{2}$ & $\mathrm{Sb}_{4}$ & $\begin{array}{c}\text { Condensed } \\
\text { species }\end{array}$ \\
\hline $\mathrm{Cd}$ & $\mathrm{Cd}$ & $\mathrm{Cd}$ & $\mathrm{CdCl}_{2}$ & $\begin{array}{c}\text { Condensed } \\
\text { species }\end{array}$ \\
\hline $\mathrm{Pb}$ & $\mathrm{Pb}, \mathrm{PbCl}_{2}$ & $\mathrm{PbS}, \mathrm{Pb}, \mathrm{PbCl}_{2}$ & $\begin{array}{c}\text { Condensed } \\
\text { species }\end{array}$ & $\begin{array}{c}\text { Condensed } \\
\text { species }\end{array}$ \\
\hline $\mathrm{Zn}$ & $\mathrm{Zn}$ & $\mathrm{Zn}, \mathrm{ZnCl}_{2}$ & $\begin{array}{c}\text { Condensed } \\
\text { species }\end{array}$ & $\begin{array}{l}\text { Condensed } \\
\text { species }\end{array}$ \\
\hline
\end{tabular}




\section{Phosphorus (P)}

It has been reported that exposure to phosphorous leads to the anode degradation and it is irreversible. According to reports from the Pacific Northwest National Laboratory (PNNL) $[9,17]$, besides arsenic, phosphorus is potentially the most harmful to the Ni-YSZ anode, which interact strongly with Ni. However, the degradation mechanism is still under debate because of the variability of reactants and resultants at anodes. Firstly, the nature of $\mathrm{P}$ compounds in the coal syngas is still not known accurately. According to the thermodynamic equilibrium calculations, $\mathrm{P}$ may exist as $\mathrm{P}_{\mathrm{x}} \mathrm{O}_{\mathrm{y}}(\mathrm{g})$ and $\mathrm{PH}_{3}(\mathrm{~g})$ depending on the temperature, steam concentration and pressure of the gas cleanup systems $[11,13]$. Both $\mathrm{P}_{\mathrm{x}} \mathrm{O}_{\mathrm{y}}(\mathrm{g})$ and $\mathrm{PH}_{3}(\mathrm{~g})$ have been chosen for $\mathrm{P}$ related effect study and all results show the cell performance loss [9-15, 17, 56-64]. Under the SOFC operating conditions, $\mathrm{PH}_{3}(\mathrm{~g})$ is believed to be the main specie in coal syngas, but it is thought to be oxidized to form $\mathrm{P}_{\mathrm{x}} \mathrm{O}_{\mathrm{y}}(\mathrm{g})$ or $\mathrm{HPO}_{2}$ because of the high steam concentration [13]. Hence, there is no evidence to determine which chemical results in the degradation even though the introduced contaminant is $\mathrm{PH}_{3}$ alone.

In addition, the reactions of $\mathrm{P}$ compounds with the anode are unclear due to the variability of the resultants. Xu et al [59-61] claimed that Ni phosphide was the primary product of the interaction of $\mathrm{Ni}$ and $\mathrm{PH}_{3}$, while $\mathrm{Zhi}$ et al $[57,58]$ found $\mathrm{Ni}$ phosphate formation. O. Marina et al. $[9,10]$ also declared in their experiments that the products were nickel phosphide $\left(\mathrm{Ni}_{3} \mathrm{P}, \mathrm{Ni}_{5} \mathrm{P}_{2}\right.$, etc) after the cell was exposed to $\mathrm{PH}_{3}$ vapor, but further XPS and ToF-SIMS results the showed existences of $\mathrm{PO}_{3}{ }^{-}$and $\mathrm{PO}_{2}{ }^{-}$ions along the cross section and surface of the anodes, which indicated the final product might be nickel phosphate instead. Because the nickel phosphate might result from the oxidization of $\mathrm{P}$ compounds during the ex-situ characterization of anode, the initial resultant of $\mathrm{P}$ based secondary phase during the cell operation is still not clear. A direct characterization method, such as in-situ test technique, is necessary to determine the realistic reactions of $\mathrm{P}$ with the anode. 


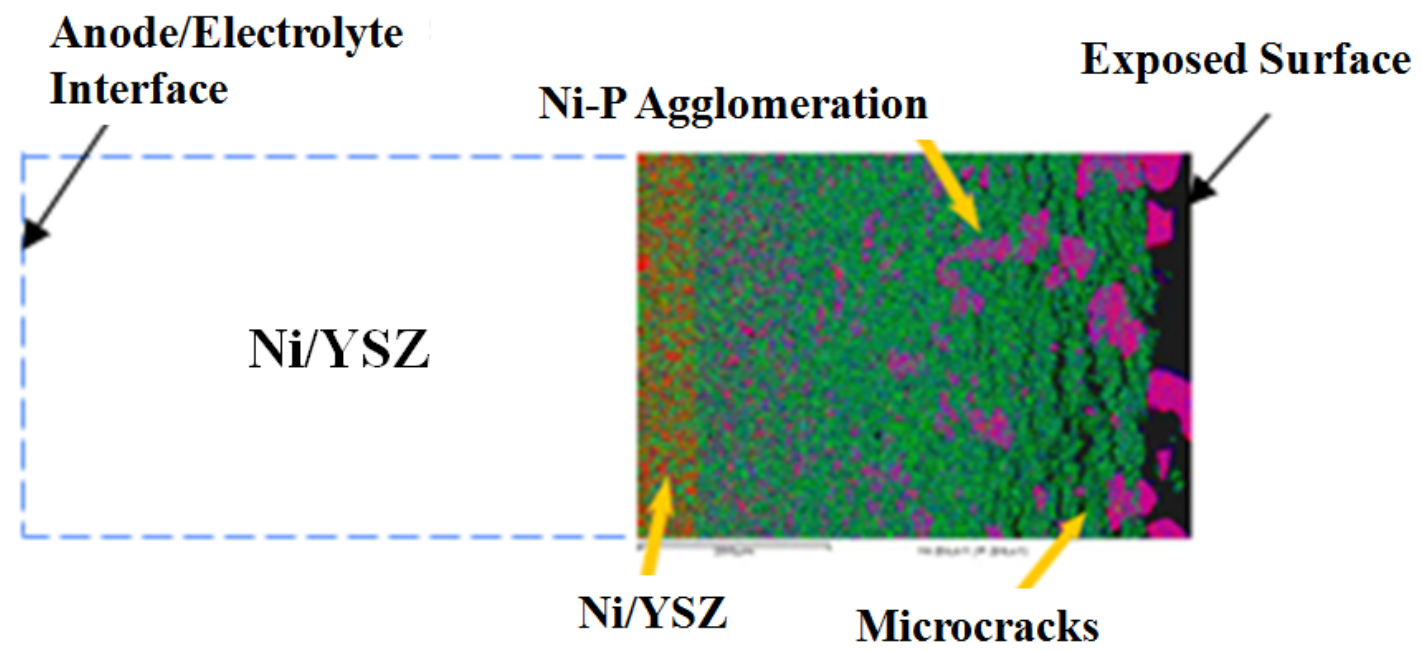

Figure 2. 4 Microstructure degradation of Ni-YSZ after $1000 \mathrm{hr}$ test at $700{ }^{\circ} \mathrm{C}$ with 5ppm of $\mathrm{PH}_{3}$ [Ref 9]

Besides the electrochemical degradation, contaminant $\mathrm{P}$ shows deleterious effects on the structural durability of SOFC anode. After exposing in $\mathrm{PH}_{3}$, a Ni-P secondary phase layer is formed on the electrode surface and penetrates through the whole anode over time, as shown in Figure 2.4. The detailed mechanism for the Ni agglomeration and migration behaviors is unknown. It might be that the addition of phosphorus $(\mathrm{P})$ depresses the melting point of $\mathrm{Ni}$ such that agglomeration of $\mathrm{Ni}$ may occur $[9,10]$, and causes reduction of electrochemical sites, which results in the degradation of the electrical conductivity and cell performance. Due to the secondary phase formation, grain growth, the redistribution of temperature and stress fields and initiation of micro-crack within the anode occur. Such changes in anode microstructure suggest the possibility of change of its modulus of elasticity and its mechanical behavior during long-term operation, even though the electrochemical degradation may be very low if an electric pathway to the active interface is maintained. 
Arsenic (As)

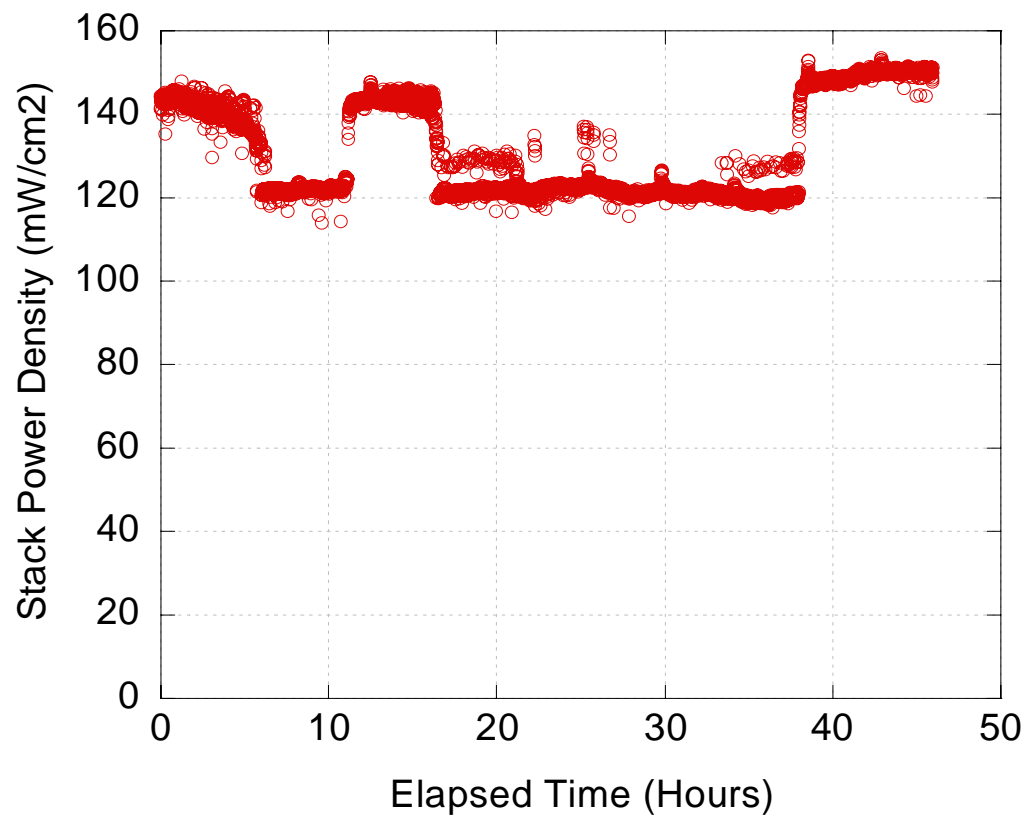

Figure 2. 5 Performance of SOFC with $10 \mathrm{ppm}$ As(g) vapor at $750^{\circ} \mathrm{C}$ after $60 \mathrm{hrs}$ [Ref 12]

Coal contains arsenic compounds primarily in the form of oxides or sulfides. Depending on the gasification process, arsenic is converted into $\mathrm{AsH}_{3}$ in the reducing environment and $\mathrm{As}_{2}$ or $\mathrm{As}_{4}$ at warm gas cleanup system conditions [12]. Krishnan et al, [12] showed that when a button cell was exposed to $10 \mathrm{ppm}$ of $\mathrm{As}_{2}$ vapor at $800^{\circ} \mathrm{C}$, the cell exhibit erratic power density level with time (Figure 2.5), and the current collector became loose and was found broken after 100 hours exposure test as shown in Figure 2.6. The degradation caused by introducing arsenic vapor is mainly due to the irreversible formation of nickel arsenide secondary phase (NiAs $[12,14]$, and/or $\mathrm{Ni}_{5} \mathrm{As}_{2}[9,10]$ ), which is less electronic conductive and decreases the performance of the hydro treating catalyst. The formation of secondary phase in the anode material will also change its modulus of elasticity and its mechanical behavior under operating conditions. 


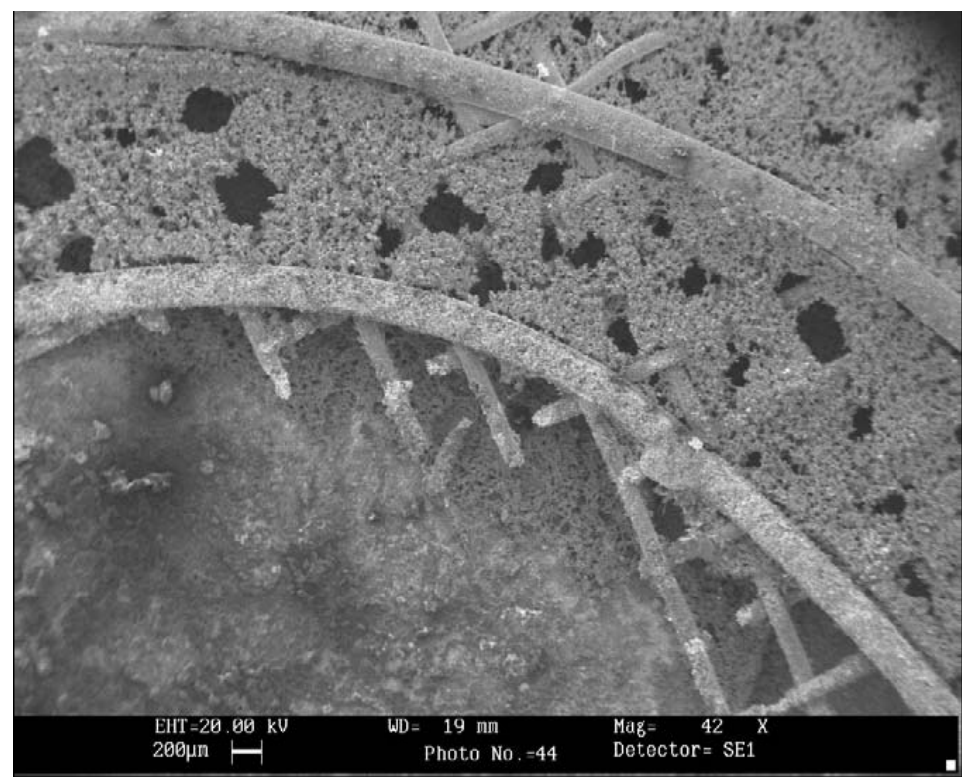

Figure 2. 6 Delaminating of Ni mesh from anode surface due to $10 \mathrm{ppm}$ As contaminant [Ref 12]

\section{Chlorine (Cl)}

$\mathrm{Cl}$ typically exists as $\mathrm{HCl}$ and $\mathrm{CH}_{3} \mathrm{Cl}$ in the coal syngas. Besides $\mathrm{HCl}$ and $\mathrm{CH}_{3} \mathrm{Cl}$, $\mathrm{Cl}_{2}$ is used for the chlorine poisoning effect on Ni-based SOFC anodes, which will react with Ni-based anodes to form nickel chlorides $\left(\mathrm{NiCl}_{2}\right)$ and block the activation region on the anode and reduce the catalytic activity $[11,15,59,66]$. The following reaction equations were used to explain the mechanism:

$$
\begin{aligned}
& \mathrm{Ni}(s)+2 \mathrm{HCl}(g) \Leftrightarrow \mathrm{NiCl}_{2}(g, s)+\mathrm{H}_{2}(g) \\
& \mathrm{Ni}(s)+\mathrm{Cl}_{2}(g) \Leftrightarrow \mathrm{NiCl}_{2}(g, s)
\end{aligned}
$$

The cell performance degradation is related with the operation temperature and the specie concentration or even the current loading. For example, Trembly et al. [15] studied the effect of $\mathrm{HCl}$ and found no significant cell degradation over 100 hours of exposure to $40 \mathrm{ppm} \mathrm{HCl}$ at $750{ }^{\circ} \mathrm{C}$ and $800{ }^{\circ} \mathrm{C}$ under $0.2 \mathrm{~A} / \mathrm{cm}^{2}$ loading. However, exposed to $20 \mathrm{ppm}$ 
$\mathrm{HCl}$ at $800{ }^{\circ} \mathrm{C}$ at approximated $0.3 \mathrm{~A} / \mathrm{cm}^{2}$ loading, SOFC performance degraded rapidly at initial state. The same phenomenon was found in the case of $900{ }^{\circ} \mathrm{C}$ and $20 \mathrm{ppm}$ level.

Although the degradation mechanism has been studied, whether the $\mathrm{NiCl}_{2}$ is in solid or gas phase format is still on debate. Haga et al [66] considered that $\mathrm{NiCl}_{2}$ was in the gas form based on the reduction of $\mathrm{Ni} / \mathrm{Zr}$ ratio and deposition of small Ni particles after test, while there was no small Ni particle deposition in the research of Trembly et al [15] and they proposed the solid form of $\mathrm{NiCl}_{2}$. Given the different test conditions, it is not suitable to compare their experimental results. Hence, the phase format has not been ascertained due to lack of a direct characterization method.

\section{Antimony (Sb)}

Under the warm gas cleanup conditions, $\mathrm{Sb}$ is mainly present as $\mathrm{SbO}_{2} \mathrm{H}_{2}$, and based on the thermodynamic equilibrium calculation, $\mathrm{Sb}$ would react with $\mathrm{Ni}$ to form $\mathrm{NiSb}$ alloy although the conversion ratio is not high ( $3.5 \%)$ [13]. According to Krishnan's study, there was no significant SOFC degradation with $8 \mathrm{ppm}$ SbO exposure at $800{ }^{\circ} \mathrm{C}$ and $850{ }^{\circ} \mathrm{C}$, while a slight cell performance improvement was observed at $750{ }^{\circ} \mathrm{C}$ [11]. Further research is needed to study the Sb poisoning effect and corresponding mechanism.

The degradation behavior of SOFC anode in coal syngas containing contaminants is strongly related to several factors, such as anode materials, operating temperatures, contaminant concentration as well as the loading overpotential. Most of the present data on the impact of the contaminants to the SOFC anode including degradation behavior and the possible tolerant limits have been summarized by Nihan et al [17] and Zhi [31]. To achieve the application of coal syngas in SOFCs, so far most research has been focused 
on the degradation mechanisms and material developments which can tolerate the contaminants, but no positive results are shown yet.

\subsubsection{Thermo-Mechanical Effects on SOFC Structure}

In addition of coal syngas contaminants, SOFC anode suffers from its harsh operating conditions. High operating temperature increases the cost of materials and decreased the cell lifetime due to the thermo-mechanical effects on SOFC structures [67]. To reduce the operating temperature and obtain high electrochemical performance, reduction in the thickness of the YSZ electrolyte, such as anode-supported thin electrolyte $[68,69,72,73]$, has been studied and utilized, as well as the use of alternative electrolyte materials $[34,41,42]$.

However, the thin layer of anode material, as a mechanical support, is inherently susceptible to mechanical failure when subjected to moderate stresses [68, 69]. A variety of stresses exist in the anode material which can arise from the coefficient of thermal expansion mismatch, residual stresses, spatial or temporal temperature, external mechanical loading, or even the microstructure reconstruction due to phase transfer caused by contaminant effects. These stresses can result in formation of microcracks or delamination of layers and degrade anode material properties. Additional research is needed in order to quantify and predict the contribution of the thermal stresses to the failure of the cell $[67,70]$.

SOFC materials also suffer from the aging effects during long-term operation. Material aging effects of stabilized zirconia components have been reported when exposed to high temperature for an extended period. The most affected property by aging effects is the strength reduction [27]. In some circumstances, the mechanical properties of multiphase brittle materials strongly depend on the level of residual micromechanical 
stresses that arise upon cooling/heating due to thermal and elastic mismatch between the constituent phases [71].

During long-term operation of SOFC, phase transformation in anode materials might occur at high temperature. Murakami et al [29] found the gradual formation of fine tetragonal phase in the cubic phase of zircon, which decreased 8YSZ conductivity and lead to higher ohmic loses. It was demonstrated that the cubic-tetragonal phase transformation boundary decreases $\left(\mathrm{mol}_{0} \mathrm{Y}_{2} \mathrm{O}_{3}\right.$ in $\left.\mathrm{ZrO}_{2}\right)$ with the temperature increase. As shown in Figure 2.7, the cubic-tetragonal phase boundary at $1000^{\circ} \mathrm{C}$ is around the 9 $\mathrm{mol} \% \mathrm{Y}_{2} \mathrm{O}_{3}$ in $\mathrm{ZrO}_{2}$, while the (tetragonal + cubic)/cubic phase boundary is located at the $\mathrm{Y}_{2} \mathrm{O}_{3}$ content of about $7.9 \mathrm{~mol} \%$ at $1400^{\circ} \mathrm{C}$. It was suggested that the phase boundary must be higher at $\mathrm{Y}_{2} \mathrm{O}_{3}$ content $(>9 \%)$ at the SOFCs operating temperature which is around $800^{\circ} \mathrm{C}$. This gradual formation of fine tetragonal phase in the cubic phase not only affect the electrochemical performance of the SOFCs but also degrade the anode material due to the elastic and thermal coefficient mismatch between the constituent phases of YSZ [67].

Another mechanism responsible for the changes of residual stresses in Ni-YSZ/YSZ bilayers at high operating temperature is creep deformation. The propensity for creep deformation of Ni-YSZ at $800^{\circ} \mathrm{C}$ was illustrated in Figure 2.8 [18]. Based on the investigation of thermal cycle and thermal aging effects on Ni-YSZ/YSZ bilayers, LaraCurzio et al, [18] demonstrated the modification of residual stresses and reduction of material strength. Creep behavior ultimately controls the design and lifetime of the components operating for prolonged periods of time at high temperatures under stresses [74]. 


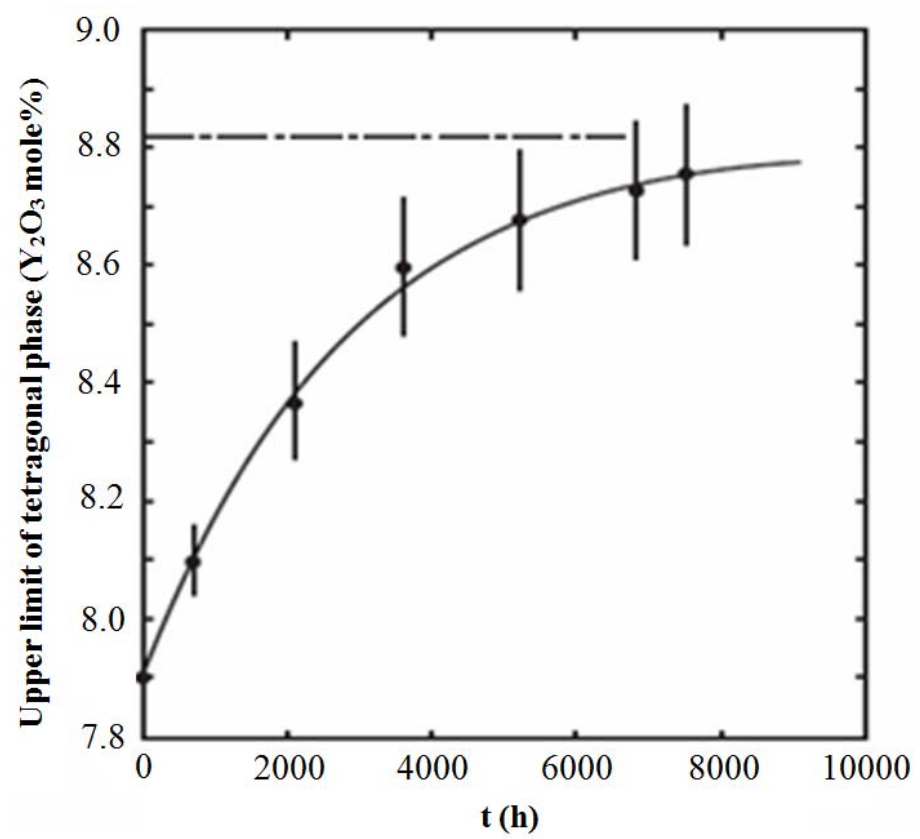

Figure 2. 7 Upper limit of tetragonal phase in $\mathrm{ZrO}_{2}-\mathrm{Y}_{2} \mathrm{O}_{3}$ system as function of aging time $t(\mathrm{~h})$ at $1000^{\circ} \mathrm{C}$ [Ref 29]

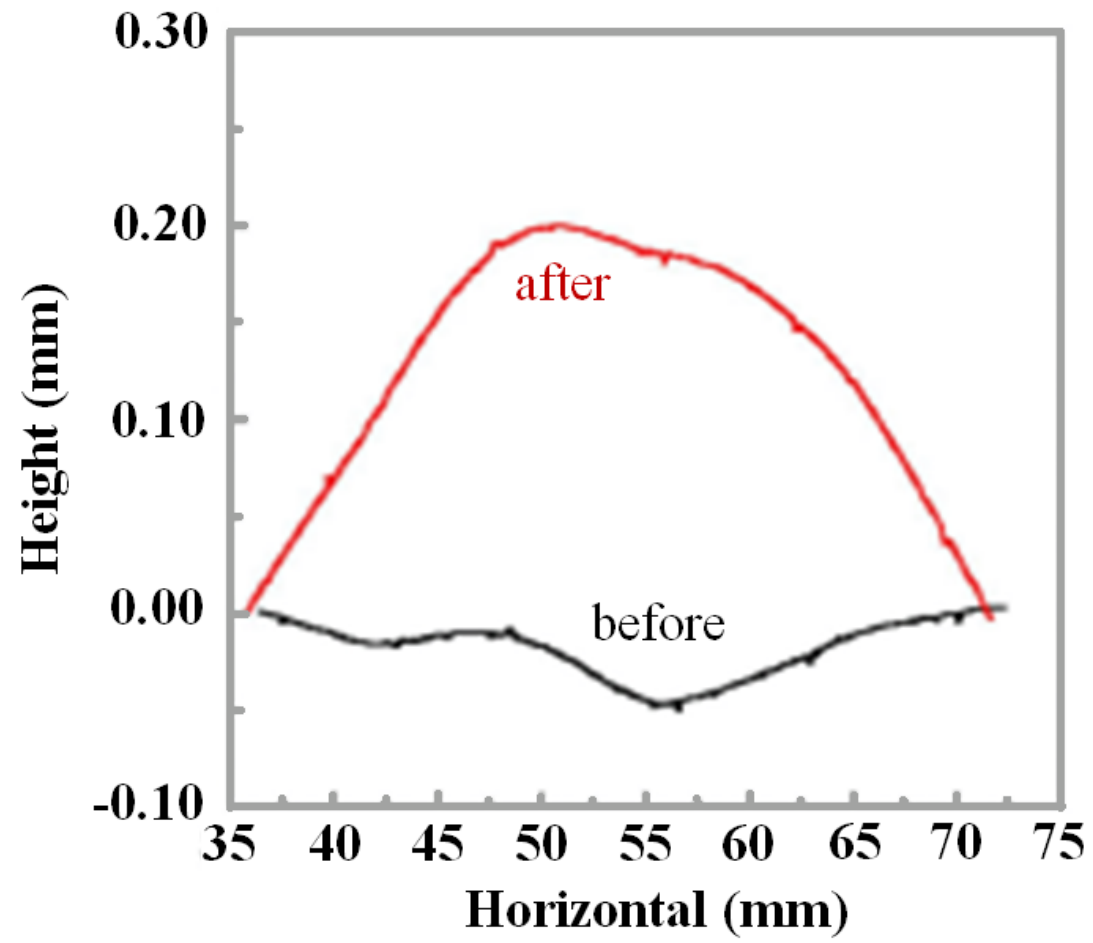

Figure 2. 8 Curvature recorded before and after 50 -hr stress relaxation test at $800^{\circ} \mathrm{C}$ at an initial elastic stress of $45 \mathrm{MPa}$ for a Ni-YSZ test specimen [Ref 18] 


\subsubsection{Redox Cycle Effects on Anode Mechanical Properties}

During operation of SOFC, the anode is supposed to be maintained in a reduced environment, but it is impractical and uneconomical. In practices, the SOFCs are anticipated to go through 5-20 cycles per year during the lifetime of the cell [75]. The 5 years expected commercial lifetime of SOFC corresponds to a total of 25 to 100 cycles. These inevitable redox cyles have deleterious effects on anode structural properties during long-term operation of SOFCs.

The microstructure and dimensional changes due to redox cycles have been studied by D. Fouquet et al [76]. Figure 2.9 shows the microstructural changes after four redox cycles on samples sintered at $1200^{\circ} \mathrm{C}$ and $1400^{\circ} \mathrm{C}$, while the correlation between $\mathrm{NiO} / \mathrm{YSZ}$ sintering temperature and particle sizes as demonstrated in Table 2.4. For the sample sintered at $1400^{\circ} \mathrm{C}$, cracks are evident caused by higher sintering temperature, and the less porosity is suggested to accommodate the volume change during oxidation. On the other hand, the oxidation of Ni-YSZ with different geometries (bars and discs) is investigated at different temperatures $\left(550-950^{\circ} \mathrm{C}\right)$ [77]. Stathis et al. [77] found that the macroscopic strain increases with the oxidation temperature; from $0.27 \%$ at $650{ }^{\circ} \mathrm{C}$ to $0.54 \%$ at $800{ }^{\circ} \mathrm{C}$. Thus the higher the oxidation temperature, larger the bulk volume change, such that the oxidation at $950^{\circ} \mathrm{C}$ caused spontaneous mechanical failure.

Table 2. 4 Percentage length change $\Delta / / l_{o}$ of $\mathrm{NiO} / \mathrm{YSZ}$ sintered at different temperature after successive redox cycles at $950^{\circ} \mathrm{C}$ [Ref 76]

\begin{tabular}{cccllc}
\hline $\begin{array}{c}\text { Sintering } \\
\text { Temperature }\end{array}$ & $1,100{ }^{\circ} \mathrm{C}$ & $1,150{ }^{\circ} \mathrm{C}$ & $1,200{ }^{\circ} \mathrm{C}$ & $1,300{ }^{\circ} \mathrm{C}$ & $1,400{ }^{\circ} \mathrm{C}$ \\
\hline After 1/2 redox cycle & 0.1 & 0.2 & 0.1 & 0.4 & 0.6 \\
After 2/3 redox cycle & 0.2 & 0.2 & 0.1 & 0.6 & 0.5 \\
After 3/4 redox cycle & 0.3 & 0.4 & 0.2 & 0.6 & 0.6 \\
\hline Total & 0.6 & 0.8 & 0.4 & 1.6 & 1.7 \\
\hline
\end{tabular}



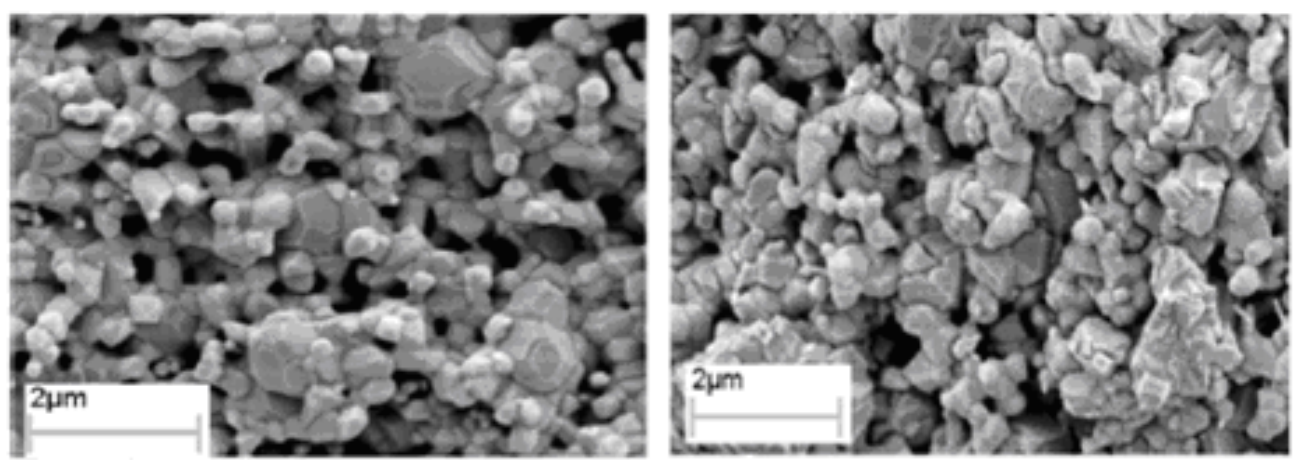

(a)
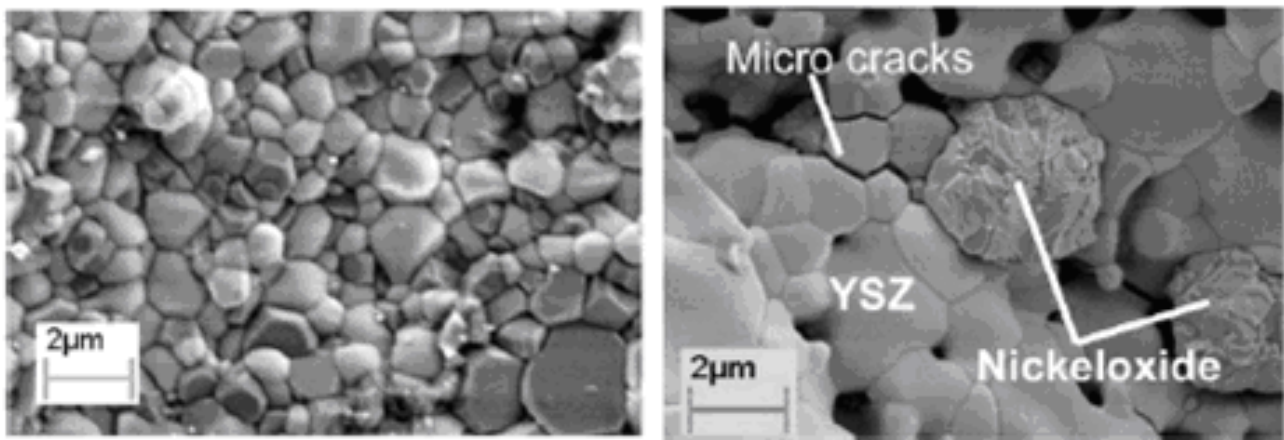

(b)

Figure 2. $9 \mathrm{NiO} / \mathrm{YSZ}$ bulk anode sample sintered at (a) $1200^{\circ} \mathrm{C}$ and (b) $1400^{\circ} \mathrm{C}$ Left: before redox cycle, Right: after passing through 4 redox cycles [Ref 76]

In a reduced environment, $\mathrm{Ni}$ in the anode (Ni-YSZ) remained in metallic form while exposed to the fuel [78]. However, as long as the fuel supply is interrupted, oxygen might continue to reach anode through electrolyte or through seal leakage and oxidize the metallic $\mathrm{Ni}$ into $\mathrm{NiO}$. If the fuel utilization is too great causing the oxygen activity to rise above that for equilibrium between $\mathrm{Ni}$ and $\mathrm{NiO}$, oxidation of the anode may also take place. The oxidation of $\mathrm{Ni}$ to $\mathrm{NiO}$ results in an increase of solid volume and the anode expands in dimension [78]. Even through the restoration of fuel supply can convert the $\mathrm{NiO}$ back into $\mathrm{Ni}$, the original state of the anode cannot be fully recovered generally. Thus the changes in anode dimension will build up over many redox cycles and generates internal stresses in the anode and other cell components that can cause microcracks, loss of performance, or even complete loss of structure integrity [78]. 


\subsubsection{SOFC Degradation Models}

Depending on the anode materials, environment and operating conditions, several mechanisms have been involved in the process of anode material degradation, which includes both electrochemical performance loss and structural durability degradation. Based on the literature review, long-term durability is an important requirement for the application of SOFC technology. Due to the limits of experimental approach, numerical modeling for SOFC long-term operation and service life assessment is essential and important for the SOFC application.

Nowadays, many studies are dedicated to understand the SOFC unit or stack properties and electrical performance, such as the reforming kinetics in Ni-YSZ anodes of a SOFC as well as the transport processes inside porous electrodes and the electrochemical reactions $[7,79-85,120,122]$. To predict the electrochemical degradation of SOFCs operating on coal syngas, F. N. Cayan [122] has developed a novel one dimensional phenomenological model to investigate the poisoning effects of coal syngas contaminants on the anode materials. In this model, model parameters are obtained through indirect calibration with the experimental data for As, P, S and Se, while the stable forms of these contaminants are determined using equilibrium calculations at SOFC operating conditions and the contaminants transport inside the porous anode is related to the anode performance. According to the parametric studies, contaminant coverage rate increases with increasing operating temperatures and contaminant concentrations, while the mixture of contaminant leads to faster degradation as compared to that of a single contaminant.

As compared to electrochemical performance modeling, the structural durability modeling for SOFCs, especially operating in coal syngas, has not been given much attention. A CDM model for glass and ceramic materials used in SOFCs has been performed and developed by Nguyen et al, [30]. This CDM model accounts for material 
degradation caused by various mechanisms i.e. void growth, void nucleation, and coalescence, in a phenomenological way through a scalar degradation variable, D (Equation (2.7)) that governs the reduction of the homogenized elastic modulus [86].

$$
E(T, D)=E_{o}(T) \cdot(1-D)
$$

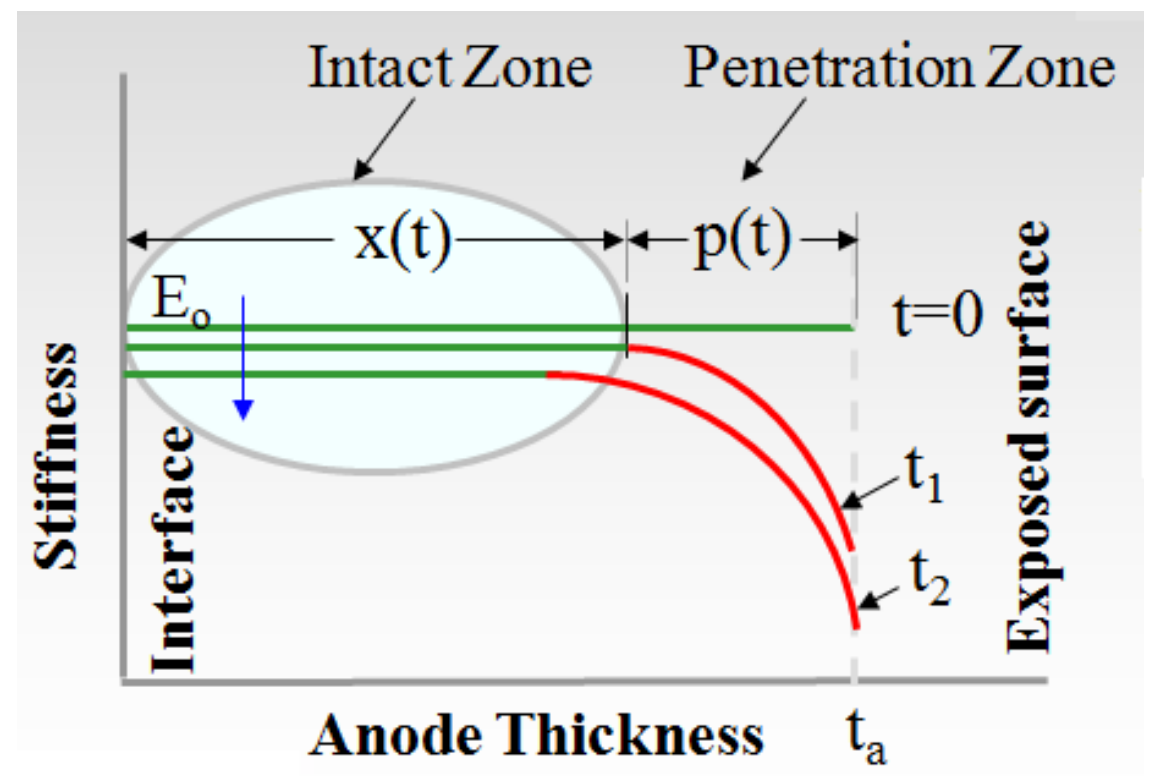

Figure 2. 10 Two degradation zones within anode thickness [Ref 89]

With respect to the anode material degradation in coal syngas, each degradation mechanism requires different degradation variable to be specified [87]. Based on the experimental investigation $[9,10,48,63]$, G. Iqbal $[67,88,89]$ in our research group has conducted failure analyses and proposed that the structural degradation of the anode can be considered into two different zones across the anode thickness: Intact Zone, $x(t)$, and Penetration Zone, $\mathrm{p}(\mathrm{t})$, as shown in Figure 2.10. The major material degradation in the intact zone is due to thermo-mechanical effects whereas the penetration zone is further degraded by the fuel gas contaminants. In his model, two degradation variables were specified: 
(1) Thermo-Mechanical Degradation Variable

$\mathrm{D}_{\mathrm{m}}$ degradation associated with the stresses and thermal aging degradation degradation due to mechanical loads

(2) Material Degradation Variable due to Coal Syngas

$\mathrm{D}_{\mathrm{c}}$ degradation associated with the chemical attack on anode syngas contaminants effect

The cumulative effect of all degradation mechanisms to which the material is exposed at the same time, is multiplicative (Equation (2.8)). The effective degradation parameter (D) is defined as following:

$$
D=1-\left(1-D_{m}\right) \cdot\left(1-D_{c}\right)
$$

$D$ still satisfies conditions typical for degradation variable;

$$
0 \leq D \leq 1, \dot{\mathrm{D}} \geq 0
$$

In the intact zone, the degradation variable $D_{c}$ is zero and the total degradation variable reduces to the thermo-mechanical degradation variable (Equation (2.9)).

$$
D=D_{m}
$$

It is important but complicated to predict the service life of SOFC materials, especially the structure integrity during long-term operation. The structure durability model developed by G. Iqbal is the first attempt to consider both thermal-mechanical and coal syngas contaminant effects on Ni-YSZ anode materials under practical operating conditions. However, due to the lack of knowledge on the mechanical phenomena in SOFC, various inputs have to be assumed in this model now, such as contaminant distribution, temperature field, or electrode mechanical properties. Thus, powerful test techniques and characterization methods are extremely attractive and required to obtain the needed electrochemical, temperature and material properties for validation and development of SOFC numerical models. 


\subsection{Characterization Methods}

\subsubsection{Electrochemical Measurements}

At present, considerable efforts are focused on the studies of SOFC electrochemical performance to understand the mechanisms responsible for fuel oxidation and power production. And two approaches are utilized for the in-situ fuel cell performance measurements [90-92].

One of the approaches is the electrochemical impedance spectroscopy (EIS), in which a sinusoidal perturbation (either current or potential) is applied to the system and the amplitude and the phase shift of the resulting current response are measured [90-92]. In the fuel cell application, EIS is utilized to clarify the cell reaction mechanisms and kinetics, while equivalent circuit fitting is built to interpret the impedance plot and to explore the fundamental electrochemical process that occur in the fuel cell. Based on the EIS measurements, lots of equivalent circuit models have been proposed for SOFC researches. However, such models are divergent and are hardly applied to explain the common behavior of fuel cells, due to complexities of fuel cell microstructure and service conditions.

Another powerful approach to characterize the fuel cell performance is to measure its current-potential-time response, derived from direct current (DC) signal, such as voltammetry (I-V curve), galvanostatic and potentiostatic methods [90-98]. In the I-V curve, the potential of the fuel cell is recorded as a variable current in a wide range is applied to the cell, while the cell power vs. current curve can also be plotted. A theoretic I-V curve is illustrated in Figure 2.11, which also reveals the cell performance loss under

different regions [92]. The more loss of the fuel cell, the less potential of the cell at given current density. The actual cell potential can be written as 


$$
V=E_{\text {theoretical }}-\eta_{a}-\eta_{\mathrm{o}}-\eta_{\mathrm{c}}
$$

As shown in Figure 2.11, $\eta_{\mathrm{a}}, \eta_{\mathrm{o}}$ and $\eta_{\mathrm{c}}$ represent the dominant loss of cell performance, respectively. The detail mechanism of the above three losses can be explained in the reference 9 and 78. Besides, galvanostatic or potentiostatic method is used to characterize the performance stability of fuel cell. In this method, a given current is applied to the cell and the cell potential is monitored. Or the potential of the cell is fixed and the current is recorded over time. This is a very valuable way to investigate the cell degradation behavior during cell operating.

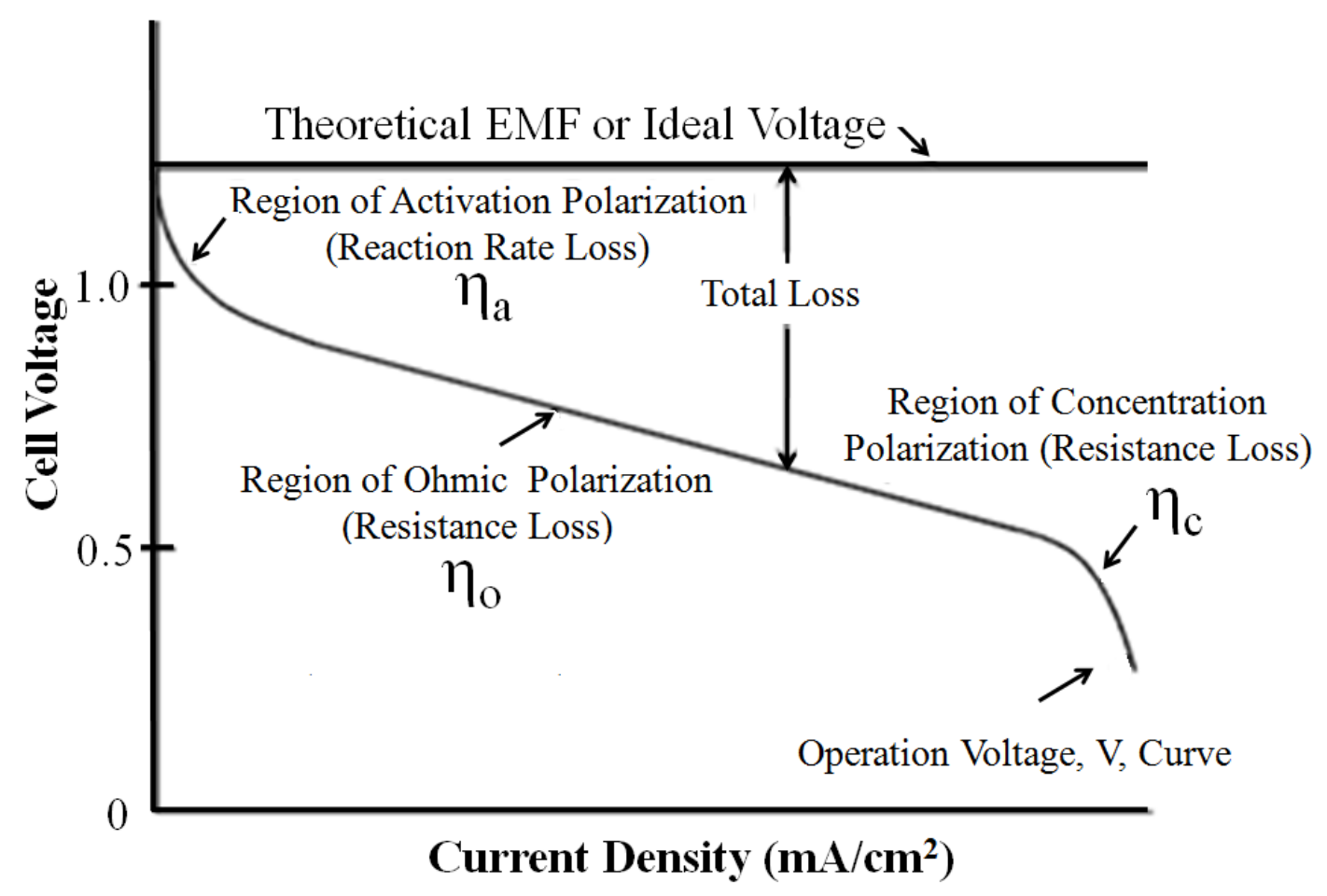

Figure 2. 11 Ideal and Actual I-V Curve for Fuel Cell [Ref 92] 


\subsubsection{Optical Analysis}

Electrochemical measurements provide detailed information about the rates of processes occurring in SOFC, but are not informative for assigning directly the molecular species that participate in the electrochemical reactions. On the contrary, optical characterization methods, i.e., Raman spectroscopy, Fourier transform infrared spectroscopy (FTIR), in-situ X-ray diffractometry, demonstrated the capabilities for not only identifying in-situ and noninvasively changes in material properties but also the formation and disappearance of molecular species on SOFC electrode surfaces [93-100].

In high temperature environments, Raman spectroscopy and Fourier transform infrared spectroscopy (FTIR) have been applied for SOFC analysis. For example, potential-dependent FTIR is utilized by M. Liu and co-workers [93] to investigate oxygen reduction and associated species absorbed on SOFC cathodes under practical operating conditions at temperatures up to $550{ }^{\circ} \mathrm{C}$. Most of these techniques are focused on cathode processes and are carried out at temperatures lower than standard SOFC operating temperature, while a few research groups are trying to extend the application of optical vibrational spectromicroscopy to SOFC anode analysis [97-99]. M. B. Pomfret et al. applied high temperature Raman spectroscopy to follow reversible oxidation/reduction kinetics of $\mathrm{Ni} / \mathrm{NiO}$ as well as the formation of nanocrystalline graphite at $715^{\circ} \mathrm{C}$. In addition, the Raman spectroscopy is supposed to provide a convenient internal diagnostic for identifying thermal gradients [97]. In Liu's group, FTIR and Raman spectroscopy are simultaneously performed to probe adsorbents and reaction intermediates on electrodes during the operation of SOFCs (up to $750{ }^{\circ} \mathrm{C}$ ) and to determine carbon deposition and sulfur poisoning effect on anodes in SOFCs [98].

These studies demonstrated the potential application of optical vibrational spectromicroscopy to indentify surface species in-situ and electrochemical reactions on anodes during the operation of SOFCs. However, little work has been done to investigate 
other coal syngas contaminants (As, P, etc) via such optical methods on SOFC anodes. The reaction mechanism and reaction intermediates on electrodes are still unknown.

\subsubsection{Surface Temperature Measurement}

SOFCs are high temperature fuel cell variants that employ oxide ion conducting ceramic electrolytes operating in the temperature range of $500-1000{ }^{\circ} \mathrm{C}$. Cells and stacks may suffer from significant temperature variation during operation that will lead to performance limitation. The ability to accurately measure the temperature distribution of SOFC systems and components is thus a powerful research and design tool for the advancement of this technology.

In order to get an accurate measurement of the cell temperature and detect temperature changes at the electrode, it is necessary to place the sensor as close to the electrodes or electrolyte as possible. For example, Adzic et al. [101] have used a 'flat type' thermocouple to probe the temperature distribution at the cathode of a plannar SOFC. However, incorporation of thermocouples close to the interface of current collector and electrode may lead to cracking of an SOFC during cell assembly or heat-up.

Infrared measurement is an ideal technique for measuring the outer surface temperature on a fuel cell or stack. As a non-contact method, IR surface temperature measurement does not disturb the behavior of the fuel cells. It allows measurements on operational fuel cells with high spatial resolution, which provides detailed data sets suitable for model input and has fast acquisition time that enables dynamic phenomena to be studied. Infrared thermal imaging has been performed on IT-SOFCs to determine the temperature changes and spatial distribution associated with different current densities for electrolyte supported pellet cells by Brett et al [102]. Currently, the near-infrared imaging and vibrational Raman scattering have been used by B. C. Eigenbrodt et al to measure the susceptibility of Ni-based anodes to carbon formation in SOFC operating with methane and methanol fuels at $715{ }^{\circ} \mathrm{C}$ [123]. The thermal imaging data show that carbon 
deposition is endothermic and reduces the anode temperatures, while the Raman spectroscopic data are used to quantify the kinetics of carbon deposition.

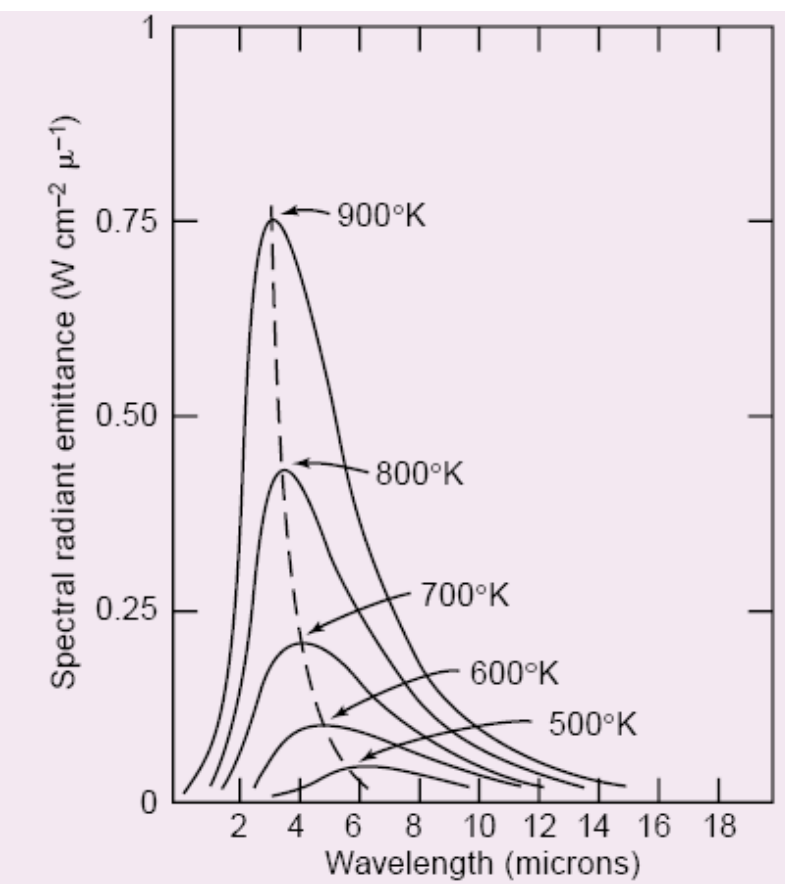

Figure 2. 12 Characteristics of Blackbody Radiation [Ref 124]

Infrared radiation was discovered in 1666 by Sir Isaac Newton. The activity of the electromagnetic spectrum was further defined in the early 1900s, while the quantitative data and equations were developed to identify IR energy. Every form of matter (of a temperature above absolute zero) emits infrared radiation according to its temperatures. This is called characteristic radiation, which is due to the internal mechanical movement of molecules, or charge displacement. The intensity of this movement depends on the temperature of the object. The infrared spectrum ranges from 0.7 to $1000 \mathrm{um}$. Figure 2.12 shows the typical radiation of the ideal, the so-called "blackbody", at different temperatures $[124,125]$. As the target temperature rises, the radiation maximum moves toward ever-shorter wavelengths, while the curves of a body do not overlap at different temperatures. The radiant energy (area beneath each curve) increases to the fourth power of its temperature, which can be represented by the Stefan-Boltzmann Law as following: 


$$
E_{\text {total }}=\varepsilon \sigma T^{4}
$$

where $\sigma=5.670 \times 10^{-8} \mathrm{JS}^{-1} \mathrm{~m}^{-2} \mathrm{~K}^{-4}$.

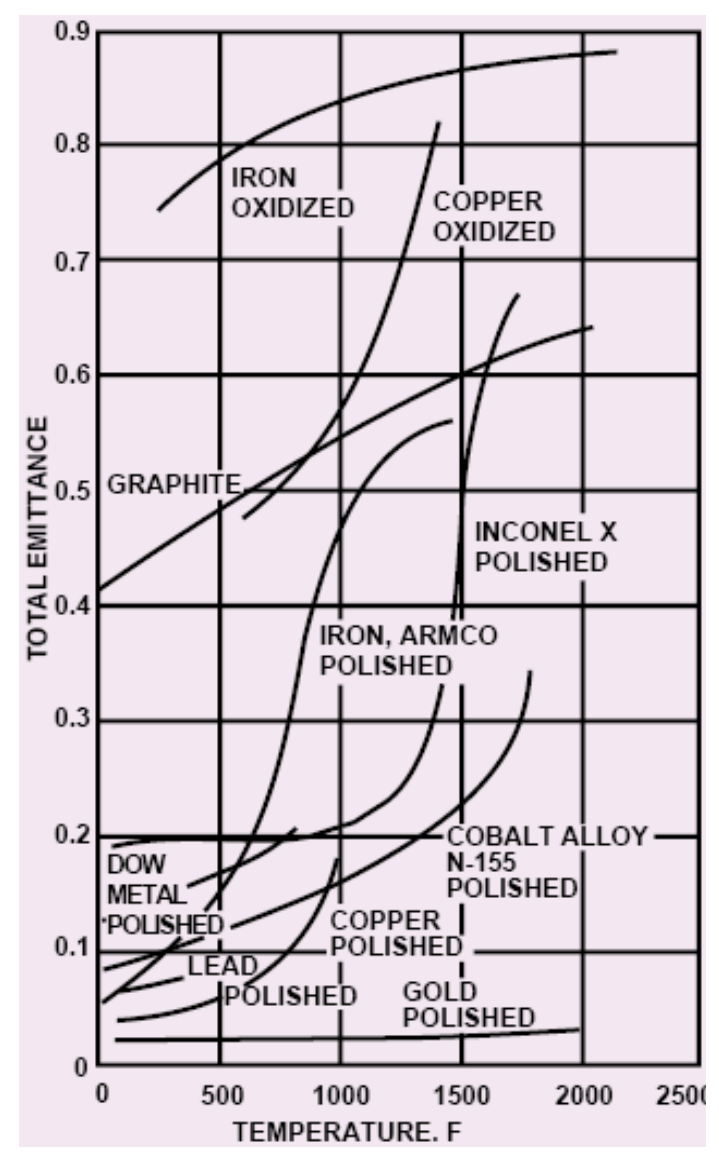

Figure 2. 13 Temperature-related Emissivity of Materials [Ref 125]

The concept of blackbody radiation is the foundation of IR thermometry. There is, however, the term "emissivity" that adds a variable to the basic laws of physics. Emissivity $(\varepsilon)$ is defined as the ratio of the real emissive power to that of a blackbody and can be a maximum of 1 (body corresponds to the ideal blackbody) and a minimum of 0 . Bodies with emissivity less than 1 are called grey bodies. Bodies where emissivity is also dependent on temperature and wavelength are called non-grey bodies. Besides temperature and wavelength, emissivity, especially of metals, can vary greatly depending upon surface finish, oxidation, or the presence of contaminants. Figure 2.13 illustrates 
examples of total emissivity for various materials that have temperature-related varying emissivity. For example, Au (polished) has a high constant emissivity of 0.03 , whereas graphite's emissivity varies from 0.4 to 0.65 between room temperature to $2000{ }^{\circ} \mathrm{F}$. For accurate IR temperature measurement and control, it is necessary but difficult to determine the exact emissivity of materials when measuring the IR temperature.

Besides emissivity of object, accurate measurement of temperature via infrared means depends strongly on the size of the object and the distance between the thermometer and the object, which is known as a field of view or FOV. The distance-tospot size ratio $(\mathrm{D} / \mathrm{S})$ defines the FOV. In particular, the thermometer will measure a fixed proportion of the energy radiated by all objects within its FOV. Thus, it should be guaranteed that the distance between the thermometer and the object is defined so that only that object fills the FOV of the instrument. For example, a D/S $=60: 1$ (OMEGA OS 3707) gives approximately a $1 \mathrm{~cm}$ spot size at a distance of $60 \mathrm{~cm}$. The shorter distance is, the smaller spot size is. However, for precise IR measurements, the infrared detector should be kept away from the heat source to avoid being heated by the environment, which also limits the application of IR pyrometer for SOFC research.

\subsection{Summary}

In this chapter, details of SOFC operation principle were presented. The degradation mechanisms to electrochemical and structural disabilities of SOFC operating with coal syngas in the presence of trace amount of contaminants were discussed, and a SOFC anode material durability model developed by Dr. Gulfam Iqbal in our group to predict long-term structural integrity of SOFC anode material was briefly reviewed. To investigate the electrode reaction and estimate the material parameters for validation and development of this SOFC numerical model, in-situ measurement techniques and characterization methods are needed. 


\section{Chapter 3: In-situ Testing Technique Development}

The lack of suitable experimental methods for directly probing the chemical transformations and structural changes in SOFCs limits the research and development of realistic numerical models for long-term prediction of SOFC operation. As described in chapter 2, optical methods show notable advantages and are capable of providing in-situ, non-contact and nondestructive SOFC testing [93-100]. In the present work, we develop an enabling technology integrating Sagnac interferometry, infrared thermometry for insitu electrode surface deformation, surface reaction investigation and surface temperature measurement of SOFC material, especially anode materials, during long-term operation. The corresponding test apparatus is built up and applied to investigate Ni-YSZ anode material parameters under realistic SOFC operating conditions. The validation of test methodology is carried out using Finite Element Analysis (FEA) and theoretical analysis.

\subsection{Introduction}

The in-situ optical testing technique, presented in this work, is developed based on the Sagnac interferometry. Prior to the test apparatus description, the introduction of Sagnac interferometer is briefly conducted as following.

The Sagnac interferometer, also referred to as a triangular-path-macrointerferometer, or a beam splitter interferometer, is an amplitude splitting device which was used in 1913 by G. Sagnac to measure the angular velocity of a rotating system [104]. More recently it has been used in applications such as fiber logic gates, laser gyroscopes, and quasi-microwave junctions $[105,106]$. The main feature of this device is that the two beams present in the system travel in identical but oppositely directed paths before they are recombined at the beamsplitter. 


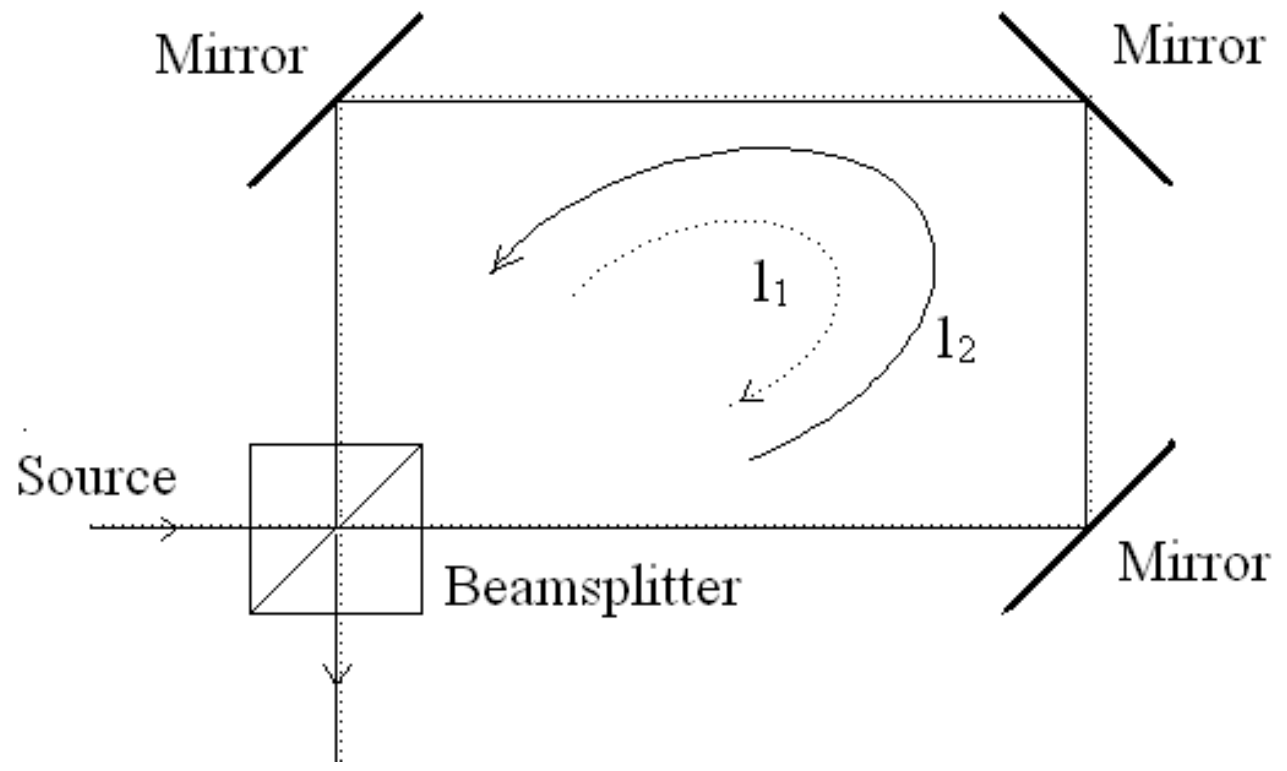

Figure 3. 1 Initial alignment of a Sagnac interferometry

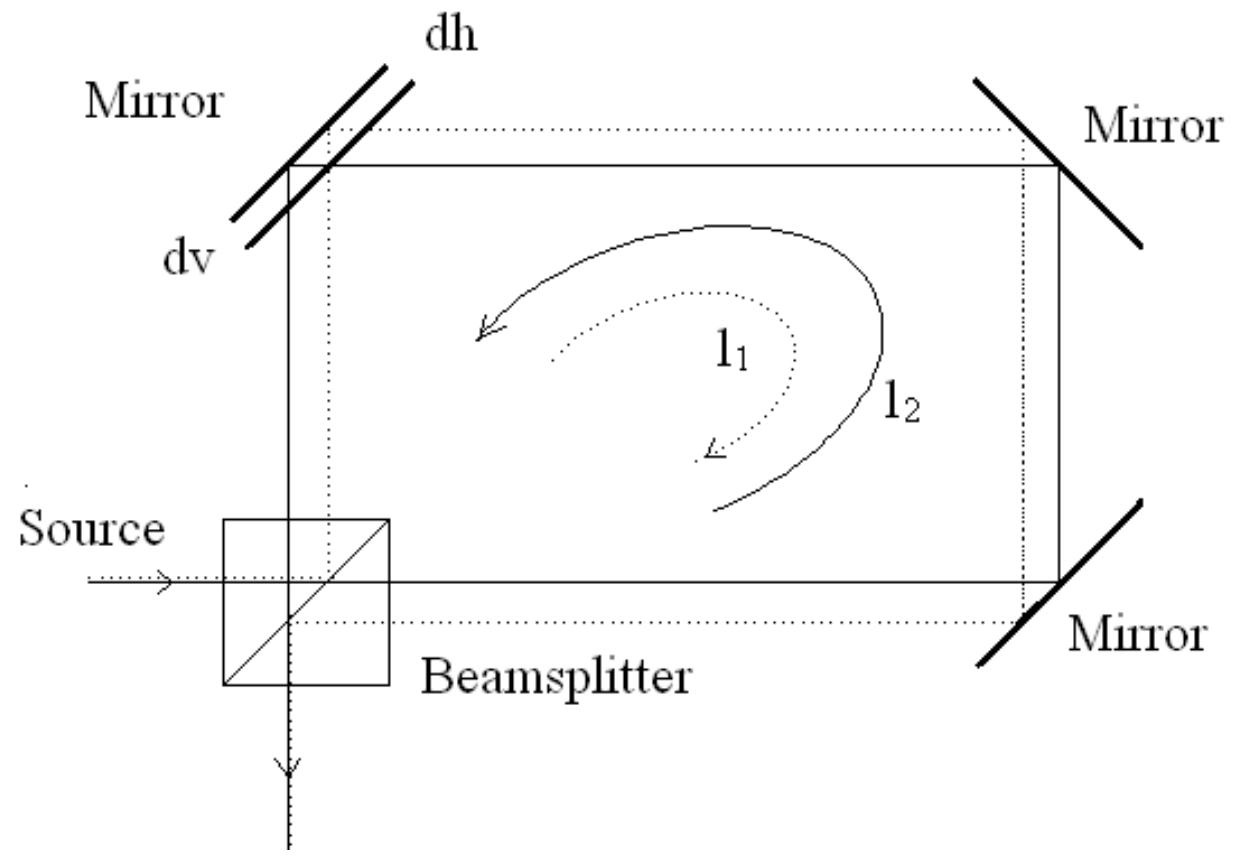

Figure 3. 2 Sagnac interferometry with translational shift (dh, dv) 
It is a device similar to Michelson interferometer, but the initial null-field (i.e. no fringes) is always achieved irrespective of the initial specimen surface warping. An example of a three mirror Sagnac interferometer is shown in Figure 3.1. A collimated wavefront is first divided by a beamsplitter into two wavefronts with the same waveform. Each waveform is then directed around an identical closed path in opposite directions and then recombined at the beamsplitter. This initial alignment produces a null-field from the interference between the recombining wavefronts, since both have the same waveshape and pathlength. When one of the mirrors is subjected to a translational shift ( $\mathrm{dh}, \mathrm{dv}$ ) as shown in Figure 3.2, an optical path difference (dl) between the two wavefronts is formed, i.e.

$$
d l=2(d v-d h)
$$

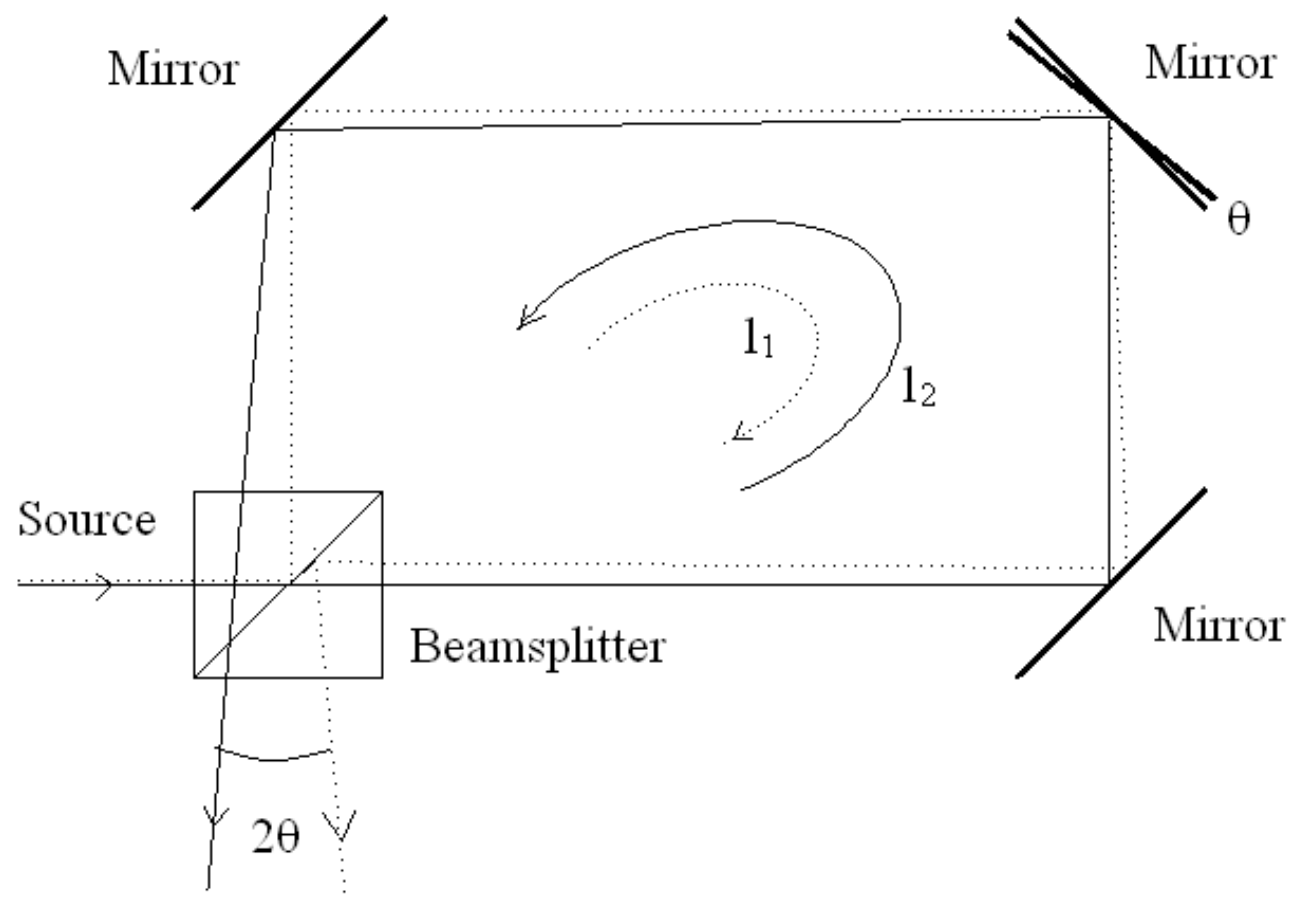

Figure 3. 3 Schematic of surface rotation

For a purely translational shift, $\mathrm{dv}$ is equivalent to $\mathrm{dh}$ and $\mathrm{dl}$ becomes zero. This corresponds to rigid body translational and no interferometric fringe will be generated. 
On the other hand, when one of the mirrors is subjected to a rotation, i.e., by an angle $\theta$, the recombining wavefronts will intersect at an angle of $2 \theta$ (as shown in Figure 3.3) and form interferometric fringes. The corresponding out-of-plane displacement can be represented by

$$
\Delta W=\frac{\Delta N \cdot \lambda}{2}
$$

where $\lambda$ is the wavelength of the light source and $\Delta N$ is the fringe order changes. From the fringe pattern images, the length of fringe pattern (L) can also be estimated. Thus, the corresponding surface slope change $(\Delta \mathrm{S}=\tan (\theta)=\Delta \mathrm{W} / \mathrm{L})$ can be calculated. The measurement sensitivity is as high as half wavelength. As illustrated in Figure 3.3, this setup is insensitive to rigid body translation as well as initial surface warping of the mirrors; however, displacements resulting from rigid body rotation of one of the surfaces will cause fringe formation.

\subsection{Test Methodology}

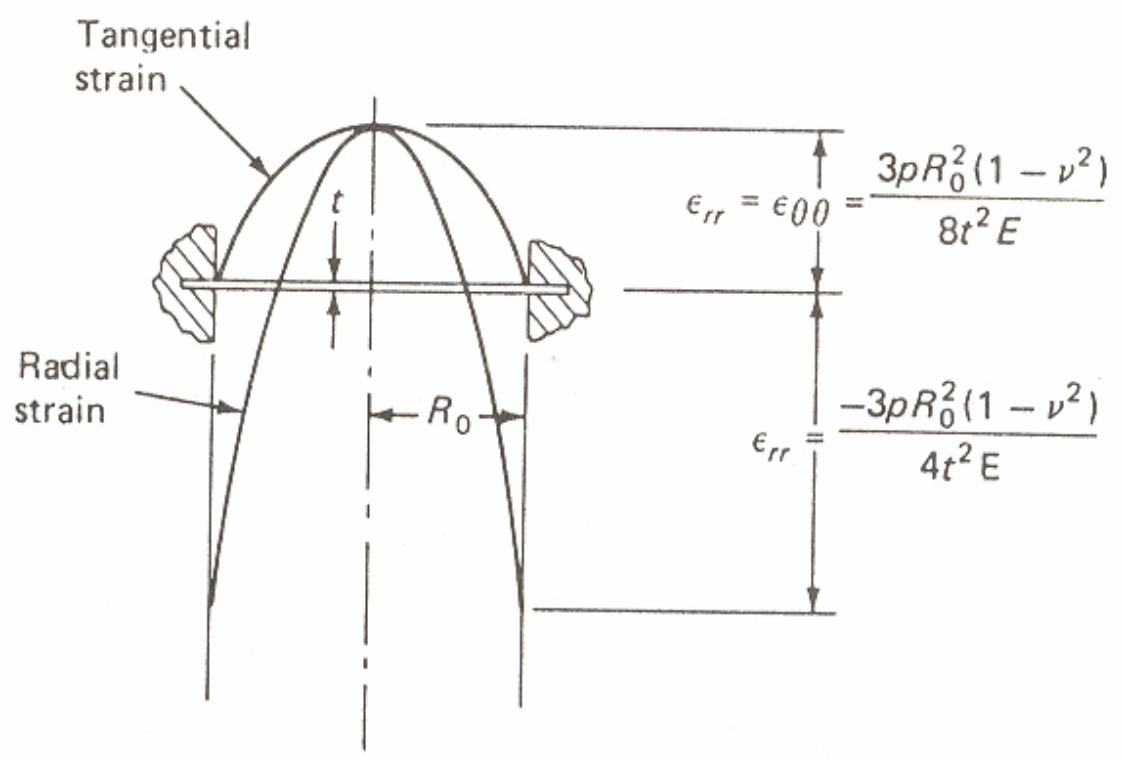

Figure 3. 4 Distribution of strain over a circularly clamped plate under uniform pressure 
In the present work, commercial anode-supported SOFC button cells were tested. The out-of-plane button cell surface deformation measurement is based on the concept of a thin circular membrane under uniformly distributed pressure. Figure 3.4 shows the strain distribution over the circular membrane. Similar to the thin circular membrane, the button cell will be artificially subjected to uniform pressure at various time intervals, and the corresponding out-of-plane deformation will be obtained using improved Sagnac interferometry. The test results can be utilized to evaluate changes of the material mechanical properties due to the degradation phenomena described in the previous chapters under coal syngas environment.

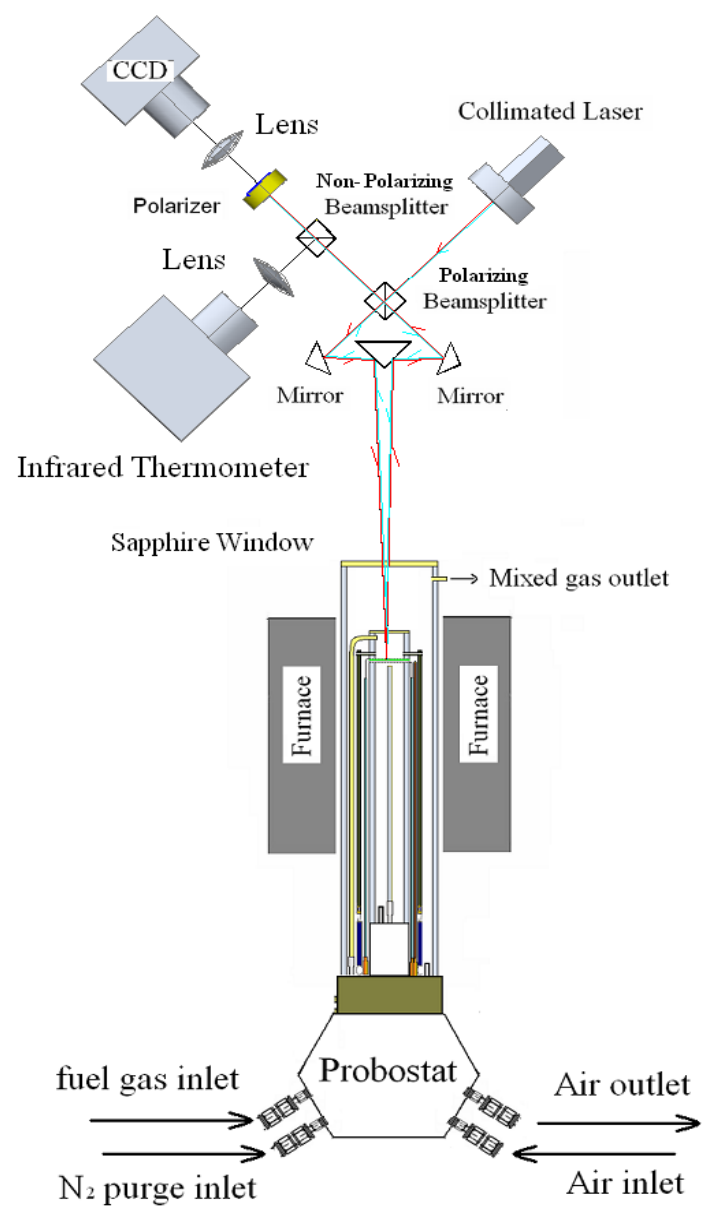

Figure 3. 5 NexTech Probostate ${ }^{\mathrm{TM}}$ integrated with Sagnac interferometry and IR thermometer 
The test apparatus with our improved Sagnac interferometry is shown in Figure 3.5 and 3.6. The NexTech Probostat ${ }^{\mathrm{TM}}$ button cell test apparatus was modified and integrated with a Sagnac interferometric optical setup and infrared (IR) thermometer. Figure 3.7 shows the fuel gas and oxidant (air) supply pattern inside the Probostat, and the detail of the button cell electrical connections. In this optical arrangement, a five-mirror Sagnac interferometer will be adopted, and one of the five mirrors of the Sagnac interferometer is replaced by the specimen (i.e. SOFC button cell), while the remaining mirrors are fixed. Thus any fringe pattern produced will be due to surface deformations of the specimen. The optical setup is capable of in-situ, non-contact, anode surface deformation and temperature measurements.

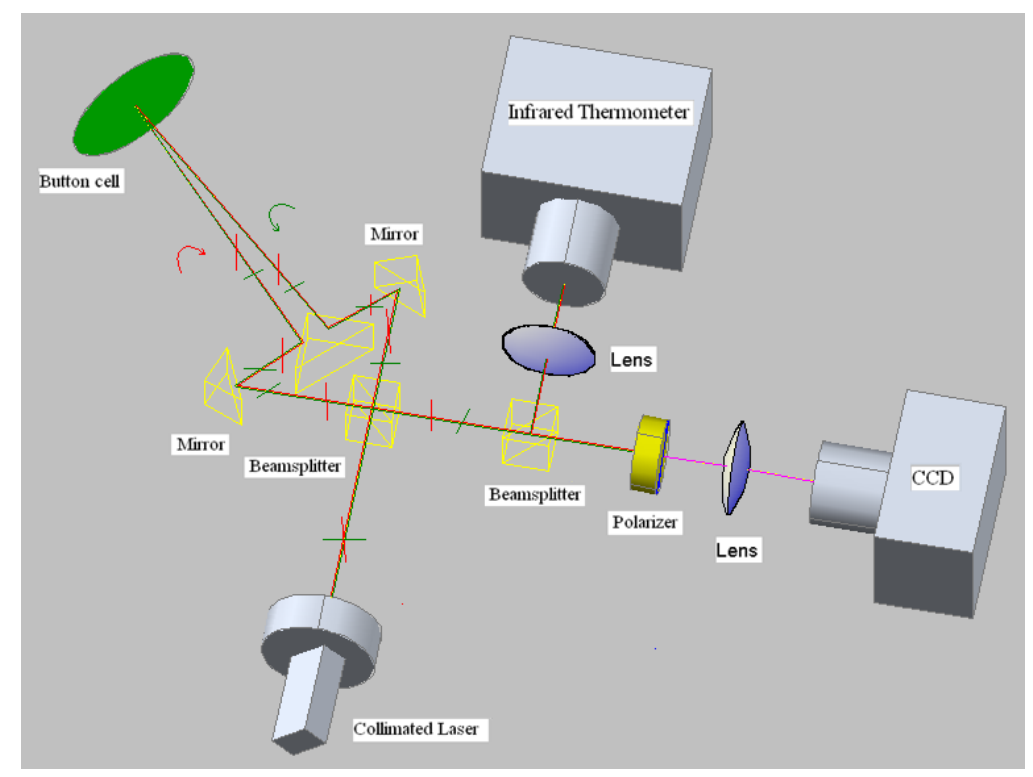

\section{Figure 3. 6 Integrated IR temperature and out-of-displacement measurement Sagnac interferometry setup}

The optical setup consists of a $20 \mathrm{~mW}$ diode laser (wave length $\lambda=658 \mathrm{~nm}$, laser spot size diameter $=2 \mathrm{~mm}$ ), beam splitters, polarizer and beam directing mirrors. A longdistance microscope fitted with a CCD camera, was used to record the fringe patterns (corresponding to out-of-plane surface rotation) and a PhotriX IR pyrometer was 
employed to measure the cell surface temperature on the same spot. With a modified and narrower field of view (FOV), the surface IR emission from the same spot of the anode surface can be captured by the PhotriX IR Pyrometer, albeit with only limited spectrum transmission $(700 \mathrm{~nm}$ to $1650 \mathrm{~nm})$. Concurrently, electrochemical performances were measured using a Solartron electrochemical interface (SI 1287) and Solartron impedance analyzer (SI 1260). The impedance spectra were collected with AC amplitude of $10 \mathrm{mV}$ at frequencies ranging from $1 \mathrm{MHz}$ to $0.1 \mathrm{~Hz}$.

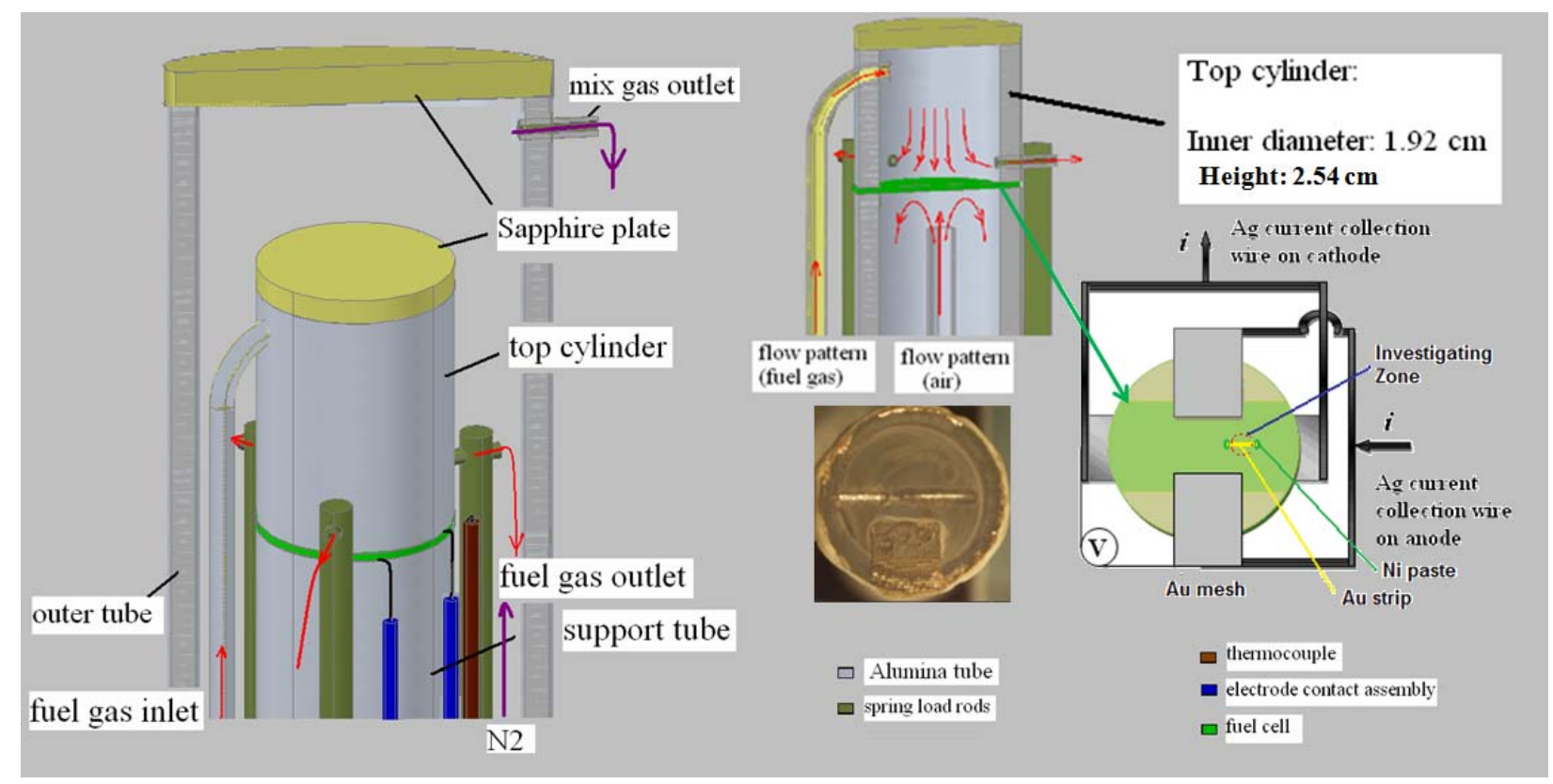

Figure 3. 7 Fuel Gas and Oxidant Supply Pattern

To obtain the fringe pattern and measure the surface deformation, a collimated laser light is split into two beams which travel in identical but opposite directed paths as shown in Figure 3.6. The beams recombine to form stable interferometric fringe patterns which are related to the surface slope change but not to rigid body motion of the testing specimen, as schematically explained in Figure 3.8. 


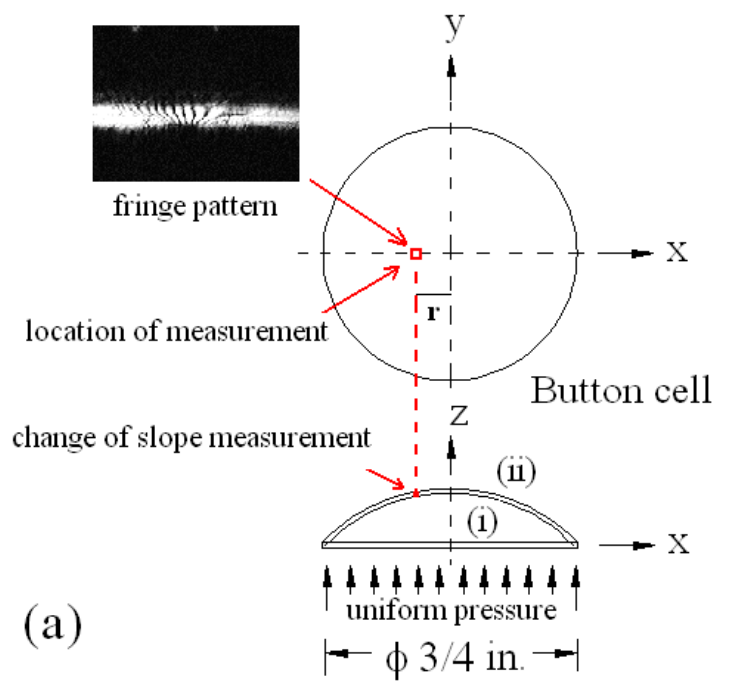

(ii)

(i)

no fringe fringes $\left(\mathbf{w}=\frac{\mathrm{N} \lambda}{2}\right)$

(i) initial curved surface (without loading)

(ii) out-of-plane surface rotation

Figure 3.8 (a) Button cell under uniform pressure with corresponding fringes on a spot location of the Ni wire mesh, (b) button cell surface rotation before and after loading.

The challenge to implement Sagnac interferometry for in-situ, non-contact surface deformation measurement of button cell is the requirement of smooth surface morphology since the measurement sensitivity is half the wavelength. After some trial runs, we found that the fringe patterns can be obtained on current collector for anode electrode, e.g., Au, Pt or Ni mesh. As shown in Figure 3.7, an Au current collection mesh was attached to the anode using nickel contact paste, while most of the anode surface was directly exposed to the injected fuel without any intervening current collector or metal paste. In order to get clear fringe patterns during button cell surface rotation, a thin and polished Au strip was attached to the target location on anode surface. Since Au (polished) has a high constant emissivity up to $2000{ }^{\circ} \mathrm{F}$, as illustrated in Figure 2.13, the Au strip had no effect on the surface IR emission measurements. Notable advantages of this technique are (i) the optical window does not affect the fringe formation, (ii) half 
wavelength measurement sensitivity, (iii) immune to temperature fluctuation and (iv) immune to vibration, making this optical technology suitable for in-situ, on-line measurement. The changes of the surface slope $(\Delta \mathrm{S})$ and the corresponding out-of-plane displacements ( $\Delta \mathrm{W})$ can be represented by Equation (3.2).

\subsection{Analytical Solution}

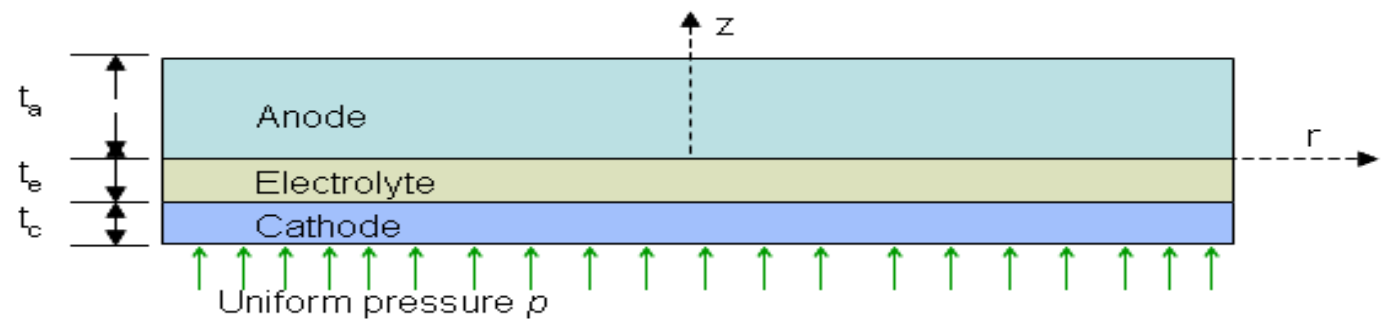

Figure 3. 9 Button cell modeled as a three-layered thin membrane. (The outer periphery of cell is fixed) [Ref 67]

To establish connection between material degradation and the related experimental measurements, a two-layer analytical solution [107] is modified to obtain surface deformation of a three-layered thin membrane under uniform pressure (Equation (3.3)), which can be considered as a button cell with anode, electrolyte and cathode layers, as shown in Figure 3.9 [67, 108, 109].

$$
W=\frac{A_{1}}{A_{1} \cdot C_{1-} B_{1}{ }^{2}} \cdot \frac{p \cdot r_{o}{ }^{4}}{64}\left[1-2\left(\frac{r}{r_{o}}\right)^{2}+\left(\frac{r}{r_{o}}\right)^{4}\right]
$$

where $W$ is the out-of-plane deflection under uniform pressure $p, \mathrm{r}_{\mathrm{o}}$ is the radius of the cell and the coefficients are defined as follow

$$
A_{1}=\int_{0}^{t a} \frac{E_{a}}{1-v^{2}} d z+\int_{-t e}^{0} \frac{E_{e}}{1-v^{2}} d z+\int_{-(t e+t c)}^{-t e} \frac{E_{c}}{1-v^{2}} d z
$$




$$
\begin{aligned}
& B_{1}=\int_{0}^{t a} \frac{E_{a}}{1-v^{2}} z d z+\int_{-t e}^{0} \frac{E_{e}}{1-v^{2}} z \cdot d z+\int_{-(t e+t c)}^{-t e} \frac{E_{c}}{1-v^{2}} z \cdot d z \\
& C_{1}=\int_{0}^{t a} \frac{E_{a}}{1-v^{2}} z^{2} \cdot d z+\int_{-t e}^{0} \frac{E_{e}}{1-v^{2}} z^{2} \cdot d z+\int_{-(t e+t c)}^{-t e} \frac{E_{c}}{1-v^{2}} z^{2} \cdot d z
\end{aligned}
$$

Lets define A, a combination of the coefficients

$$
A=\frac{A_{1}}{A_{1} \cdot C_{1}-B_{1}^{2}}
$$

The change of slope with the applied pressure can be obtained by differentiating Equation (3.3) with respect to the radius $r$.

$$
\frac{\partial W}{\partial r} / p=\frac{A}{16}\left(r^{3}-r . r_{o}^{2}\right)
$$

\begin{tabular}{|c|c|c|c|c|}
\hline \multicolumn{3}{|c|}{ Button Cell Specification } & \multicolumn{2}{|c|}{$\begin{array}{l}\text { Out-of-Plane Displacement at } \\
\text { Center } r=0\end{array}$} \\
\hline Anode & Electrolyte & Cathode & \multirow[b]{2}{*}{$\mathrm{W}_{\text {Analytical }}$} & \multirow[b]{2}{*}{$\mathrm{W}_{\mathrm{FEA}}$} \\
\hline $\mathrm{t}_{\mathrm{a}}=600 \mu \mathrm{m}$ & $\mathrm{t}_{\mathrm{e}}=10 \mu \mathrm{m}$ & $\mathrm{t}_{\mathrm{c}}=50 \mu \mathrm{m}$ & & \\
\hline$u_{a}=0.317$ & $u_{e}=0.310$ & $u_{c}=0.300$ & \multirow{3}{*}{$6.569 \mu \mathrm{m}$} & \multirow{3}{*}{$6.520 \mu \mathrm{m}$} \\
\hline $\mathrm{E}_{\mathrm{a}}=1.05 \mathrm{e} 11 \mathrm{~N} / \mathrm{m}^{2}$ & $\mathrm{E}_{\mathrm{e}}=2.125 \mathrm{e} 11 \mathrm{~N} / \mathrm{m}^{2}$ & $\mathrm{E}_{\mathrm{c}}=1.1 \mathrm{e} 11 \mathrm{~N} / \mathrm{m}^{2}$ & & \\
\hline \multicolumn{3}{|c|}{ Cell Radius $=12.5 \mathrm{~mm} \quad$ Applied Pressure $=50 \mathrm{kPa}$} & & \\
\hline
\end{tabular}

Table 3. 1 Numerical and Analytical results of out of plane deformation a button cell under uniform pressure

The three-layered thin membrane analytical solution is validated using finite element analysis packages ABAQUS ${ }^{\mathrm{TM}}$ and MSC-Marc ${ }^{\mathrm{TM}}$, which is conducted by Dr. Gulfam Iqbal [67, 108, 109], as shown in Table 3.1. Equation (3.4) also provides the location of the maximum change of slope per unit applied pressure. It is at $1 / \sqrt{ } 3$ of the normalized radius of the button cell from the center. For this research, test results were conducted on this location. 
In practical SOFC button cell testing, the button cell periphery is not clamped but relatively free to rotate similar to a simply supported circular plate. This requires a compensating factor to be included in Equation (3.4). By comparing the analytical solution of a clamped and simply supported single layer circular plate under uniform pressure [110], we deduced that the slope of the simply supported plate can be obtained from the slope of the clamped plate by multiplying it with the following compensating factor $\mathrm{C}_{0}$.

$$
C_{o}=\left[\left(r / r_{o}\right)^{2}-(3+v) /(1+v)\right]\left[1-\left(r / r_{o}\right)^{2}\right]^{-1}
$$

At the location of maximum slope change $\left(r / r_{0}=1 / \sqrt{ } 3\right)$ and assuming Poisson ratio of $\nu=0.3$, the compensating factor from Equation (3.5) is $\mathrm{C}_{\mathrm{o}}=3.31$. From FE analysis of the multi layered model, the compensating factor is estimated to be in the range of 3.39 to 3.55. For modeling purposes, the compensating factor is assumed as 3.5. The Equation (3.4) can now be written in the following form.

$$
\frac{\partial W}{\partial r} / p=C_{o} \frac{A}{16}\left(r^{3}-r \cdot r_{o}^{2}\right)
$$

From the proposed experimental surface deformation measurement, anode material Young's modulus can then be determined from the three-layer model. Thus, a test methodology of long-time monitoring of SOFC anode structural integrity under simulated coal syngas service condition can be carried out. Coupled with in-situ temperature, I-V and EIS measurements, correlation between the SOFC mechanical degradation and electro-chemical degradation can be further studied. If the change in Young's modulus of electrolyte and cathode is negligible as compare to change in anode Young's modulus, we can obtain the change in anode effective Young's modulus by using Equations (3.3) and (3.6) and by determining the change of slope of the button cell experimentally, and thus estimate the mechanical degradation of the anode material. 


\subsection{Surface Deformation Measurements}

According to Equation (3.4), the location of the maximum change of slope per unit applied pressure was determined and the fringe patterns were obtained on Au strip located at $1 / \sqrt{ } 3$ of the normalized cell radius from the center of the button cell. Through the mass flow controller (MFC), the gas flow rate and pressure is controlled. The button cell is then artificially subjected to the adjusted air pressure on cathode side at various time intervals, and the corresponding surface deformation is monitored.

It should be noted that the flow rate and pressure of air on cathode side, which are adjusted for the surface deformation measurement, might affect the performance of SOFC. Figure 3.10 shows the power density history plot of the button cell during the cathode side air pressure changes using gas valves for the surface deformation measurement. The cell was operating at $800^{\circ} \mathrm{C}$ and current density $0.5 \mathrm{~A} / \mathrm{cm}^{2}$ with 100 sccm $\mathrm{H}_{2} / 3$ vol. $\% \mathrm{H}_{2} \mathrm{O}$ on anode side and $300 \mathrm{sccm}$ air on cathode side, respectively. The cell performance was stable over time. However, it was affected significantly by the cathode side air supply interruption as shown in Figures 3.10(b) and (c). The cell performance degraded immediately as the air flow decreased from $300 \mathrm{sccm}$ to $100 \mathrm{sccm}$ (point " 1 ") and increased as the air outlet valve was closed (point " 2 "). It degrades again as the air inlet valve was closed at desired pressure (point " 3 ") and recovered gradually when the air inlet valve was opened again to increase pressure (point "4"). On the basis of electrochemical polarization $[115,116]$, oxygen starvation to the cathode side can explain the abrupt cell performance degradation. This procedure was repeated for each pressure increment to measure surface deformation. After each measurement, both air outlet and inlet valves were opened again and air flow was resumed to $300 \mathrm{sccm}$. As shown in Figure 3.10(b), the cell performance immediately returned to about $70 \%$ of the initial value (point "5"). However, it might take more than $24 \mathrm{hrs}$ to fully recover. Such phenomenon can also be seen by just turning on/off cathode side air supply, as shown in Figure 3.10 (c). The cell voltage dropped to the negative range that might cause cell delamination. 

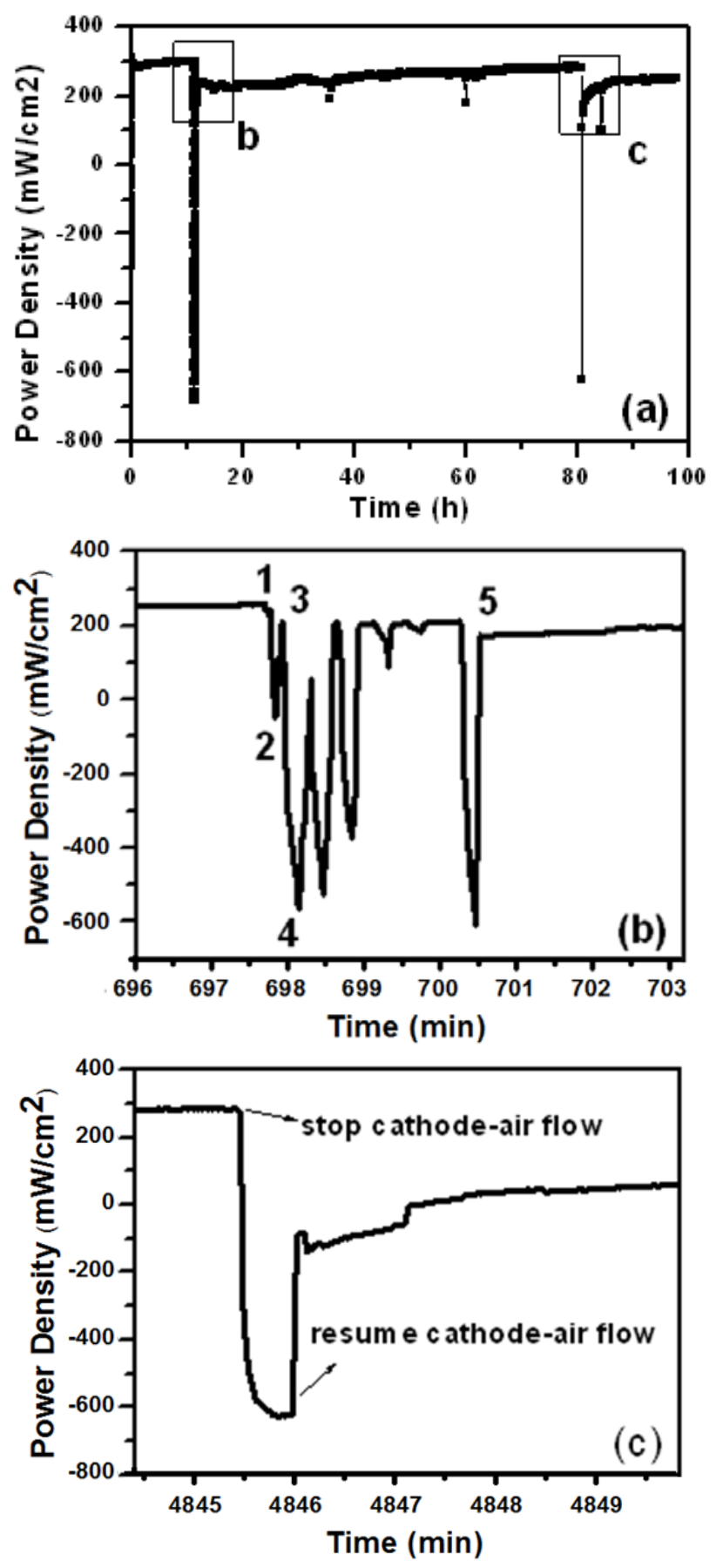

Figure 3. 10 (a) Button cell power density plot during pressure changes (b) Effect of cathode side air pressure, (c) Effect of cathode side air flow rate 


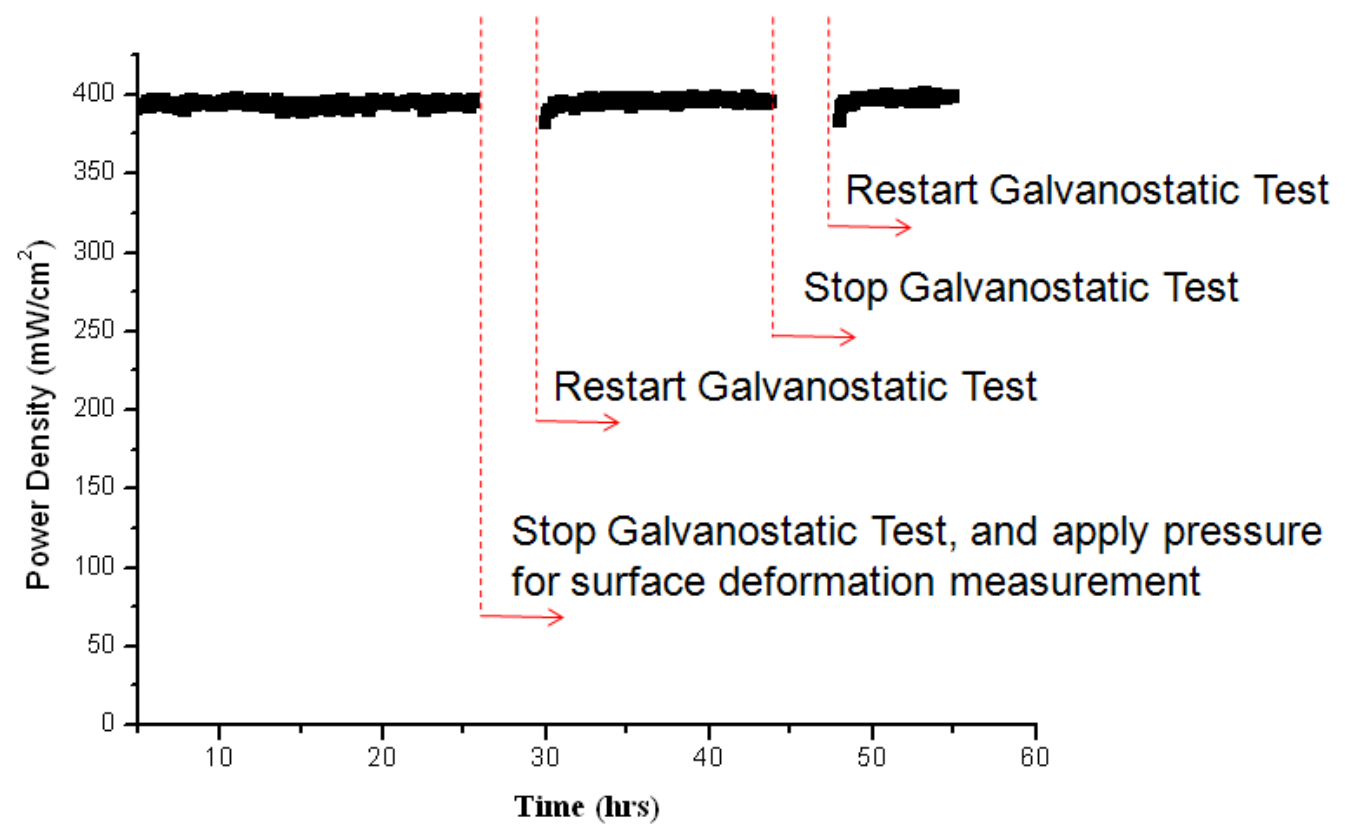

Figure 3. 11 Remedy of Cathode-air Interruption on performance of SOFC with 100 sccm $\mathrm{H}_{2} / 3$ vol. \% $\mathrm{H}_{2} \mathrm{O}$ at $800{ }^{\circ} \mathrm{C}\left(0.5 \mathrm{~A} / \mathrm{cm}^{2}\right)$

A proper remedial procedure is developed to minimize cathode-air interruption on SOFC performance. A pressure relief valve is utilized to control cathode-air pressure without need to turn off air supply and avoid the deficiency of oxygen at the reaction site of cathode, while galvanostatic test is stopped when the cathode-air pressure is adjusted for the out-of-plane surface deformation measurement. Preliminary test data indicated that the pressure interruption is minimized through this process as shown in Figure 3.11.

Preliminary work was carried out at room temperature (RT) with an in-house room temperature test apparatus, and a NexTech Probostat ${ }^{\mathrm{TM}} \mathrm{SOFC}$ button cell test apparatus at $800^{\circ} \mathrm{C}$. The corresponding fringe patterns are shown in Figure 3.12 and 3.13, respectively. As shown in Figure 3.12(a) and 3.13(b), the initial fringe patterns without applied pressure were due to the initial curved surface of the Ni wire. The fringe patterns changed as the air pressure applied on the cathode side increased, as shown in Figure 3.12(b), 3.12 
(c), 3.13(c), 3.13(d) and 3.13(e). The slope change per unit applied pressure was calculated for both the RT and $800^{\circ} \mathrm{C}$ cases by counting the changes of fringe order versus applied pressure.
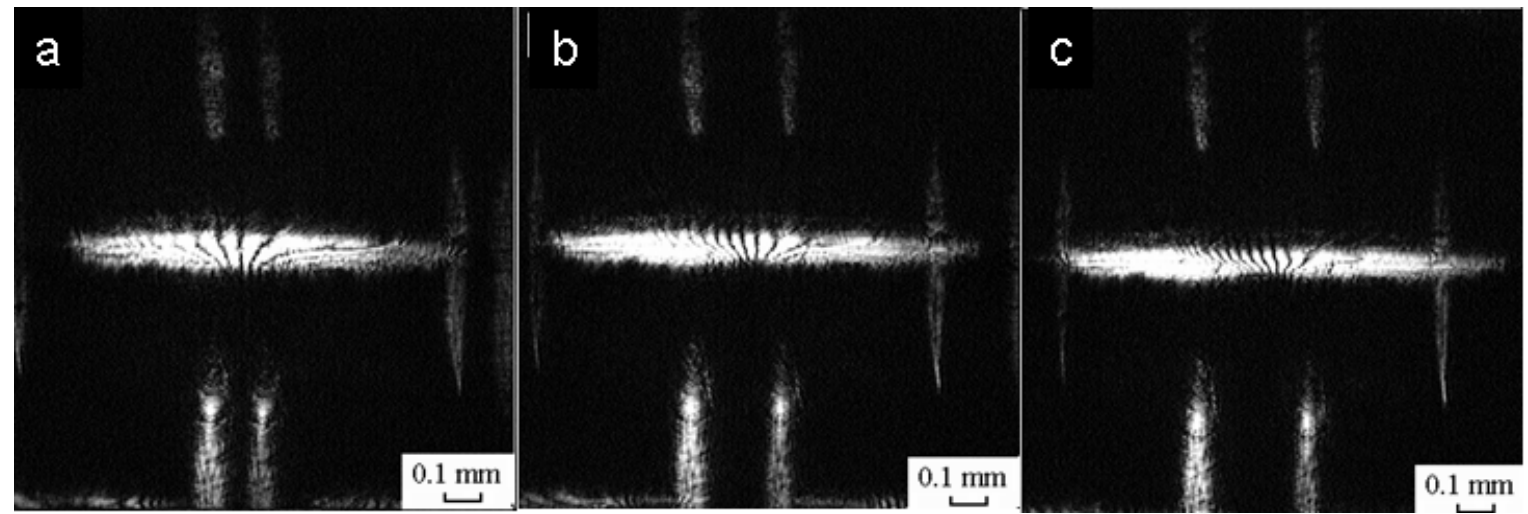

Figure 3.12 Fringe patterns on $\mathrm{Ni}$ mesh at $\mathrm{r}=3 \mathrm{~mm}$ from the center with different applied pressures: (a) 0 psi, (b) 7 psi and (c) 13 psi

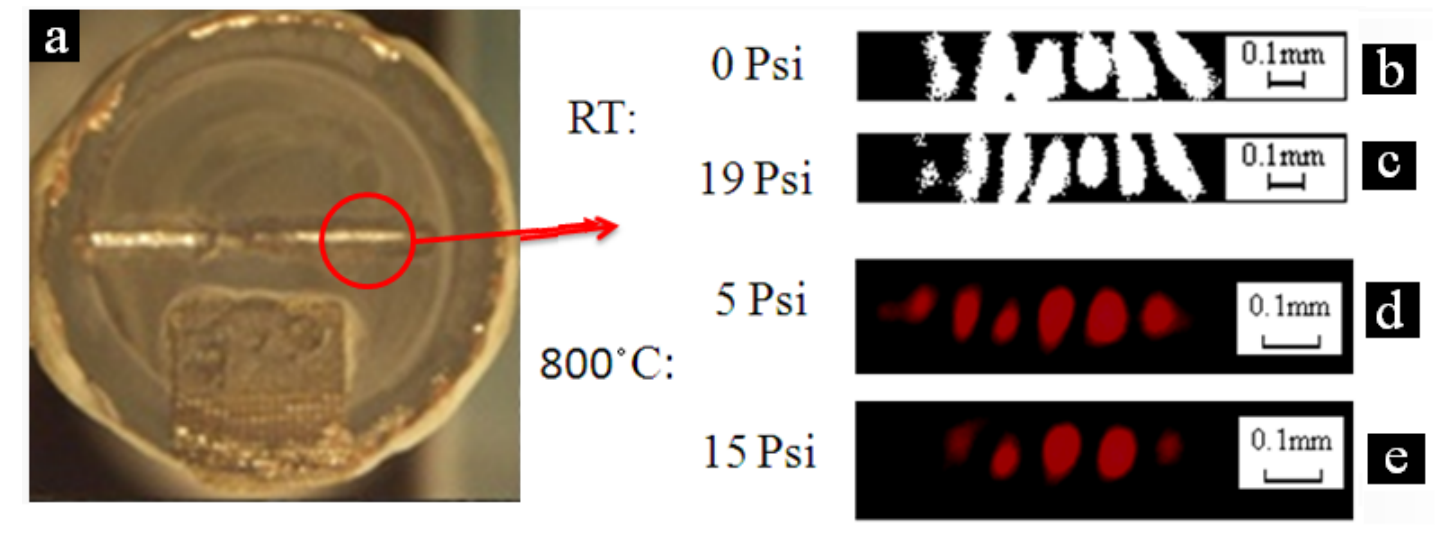

Figure 3. 13 (a) Au strip image on a SOFC button cell and Fringe patterns at $r=5.5$ mm from the center using NexTech Probostat ${ }^{\mathrm{TM}}$ test apparatus with different applied pressures: (b) 0 psi and (c) 19 psi at RT, (d) 5 psi and (e) 15 psi at $800{ }^{\circ} \mathrm{C}$

For validation, analytical analysis and finite element analysis packages ABAQUS ${ }^{\mathrm{TM}}$ and MSC-Marc ${ }^{\mathrm{TM}}$ were carried out by Dr. Gulfam Iqbal [67, 108, 109]. The comparison among experimental, FE simulation and analytical prediction is shown in Table 3.2 [67]. As shown, good agreement is noted and the results are within 5\% error. Coupled with in- 
situ surface temperature and cell electrochemical measurements, correlation between the SOFC mechanical degradation and electrochemical degradation can be further studied.

Table 3. 2 Comparison among experimental, FE simulating and analytical prediction

\begin{tabular}{|c|c|c|c|c|c|}
\hline \multirow{2}{*}{\multicolumn{2}{|c|}{$\begin{array}{c}\text { Applied Pressure } \\
\text { (Psi) }\end{array}$}} & \multicolumn{2}{|c|}{ Experimental Results } & \multirow{2}{*}{$\begin{array}{c}\text { Simulation Result } \\
\qquad \Delta \mathrm{S} / \Delta \mathrm{P}\end{array}$} & \multirow{2}{*}{$\begin{array}{c}\text { Analytical } \\
\text { Result } \Delta \mathrm{S} / \Delta \mathrm{P}\end{array}$} \\
\hline & & Slope S & $\Delta \mathrm{S} / \Delta \mathrm{P}$ & & \\
\hline room & 5 & $4.038 \times 10^{-3}$ & & & \\
\hline temperature & 10 & $4.227 \times 10^{-3}$ & $3.82 \times 10^{-5}$ & $3.70 \times 10^{-5}$ & $3.81 \times 10^{-5}$ \\
\hline (RT) & 15 & $4.420 \times 10^{-3}$ & & & \\
\hline \multirow[t]{3}{*}{$800^{\circ} \mathrm{C}$} & 5 & $5.484 \times 10^{-3}$ & & & \\
\hline & 10 & $5.185 \times 10^{-3}$ & $5.95 \times 10^{-5}$ & $6.32 \times 10^{-5}$ & $6.23 \times 10^{-5}$ \\
\hline & 15 & $4.889 \times 10^{-3}$ & & & \\
\hline
\end{tabular}

\subsection{Surface IR Emission Measurements}

Based on the advantages of Sagnac interferometer, our optical unit is immune to the system vibration and temperature fluctuation. In addition of surface deformation measurement, the surface IR emission can be monitored when a PhotriX IR pyrometer is incorporated, as shown in Figure 3.5 and 3.6. The Sagnac interferometer unit is used to modify the field of view (FOV) of infrared pyrometer. As mentioned in the previous chapter, the infrared detector should be kept away from the heat source to avoid being heated by the environment. The wide FOV of IR pyrometers limits their application for SOFCs operating at high temperature. With a narrower FOV, precise IR emission measurements on the surface of high temperature SOFCs or stacks using a cheaper IR detector can be achieved, avoiding the thermal effects of operational environment. In the present work, as mentioned, a thin and polished Au strip was attached to the target 
location on anode surface for fringe pattern formation. Even through the coverage of $\mathrm{Au}$ strip on anode surface is abour $60 \%$, Au (polished) has a high constant emissivity up to $2000{ }^{\circ} \mathrm{F}$ [125] and thus it will not affect the button cell surface IR temperature measurements. During the fuel cell operation, the surface temperature variations obtained via our optical unit with IR pyrometer are just related to the fuel cell performance changes. This technique will provide detailed data sets suitable for numerical model input and has high spatial resolution and fast acquisition time that enables dynamic phenomena to be studied.

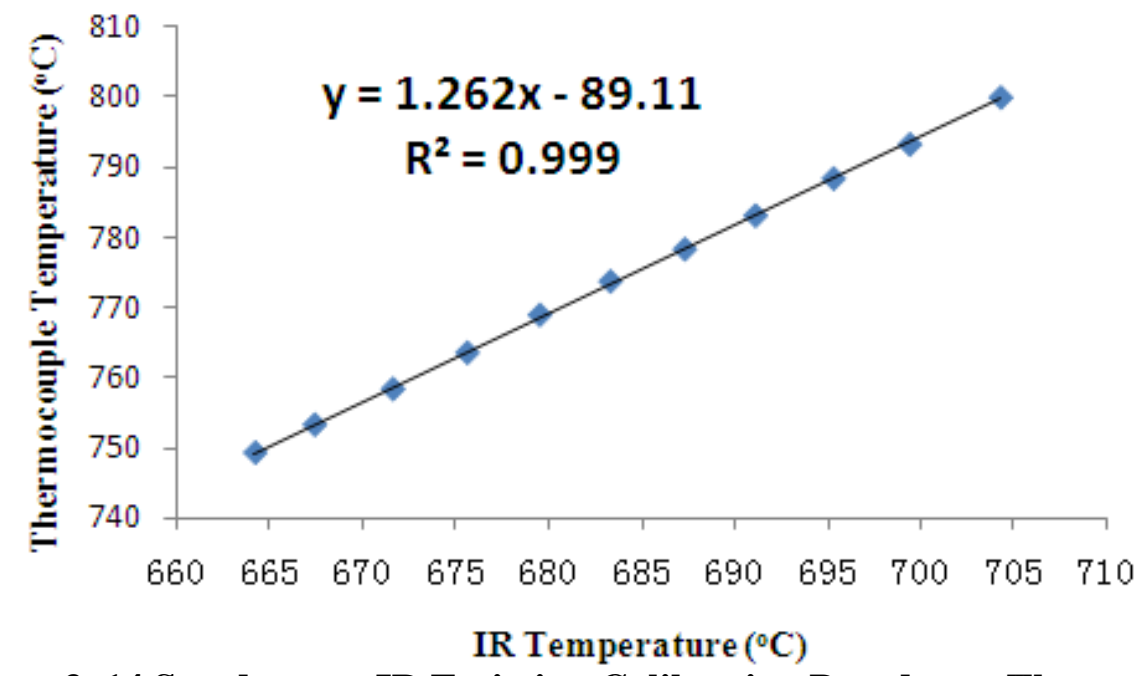

Figure 3. 14 Steady-state IR Emission Calibration Based on a Thermocouple Measurement

Prior to the surface IR emission measurements for operational SOFC, IR thermometer calibration has to be carried out. Thus, after completing the fuel cell reduction at $750^{\circ} \mathrm{C}$, the in-situ IR temperature calibration was conducted with an embedded thermocouple close to the fuel cell, from $750^{\circ} \mathrm{C}$ to $800^{\circ} \mathrm{C}$ with $5^{\circ} \mathrm{C}$ steps. During each discrete temperature step, the fuel cell was heated slowly at $0.5^{\circ} \mathrm{C} / \mathrm{min}$ and then kept at steady state condition for 30 minutes. Temperature data were recorded from IR Pyrometer and thermocouple simultaneously under steady state conditions. As shown in Figure 3.14, the thermal calibration data was linear, which can be extrapolated to transform the IR emission into transient temperature during SOFC operation. The 
standard deviation of the calibration line is 0.04 , and the uncertainty of the temperature measurement is $\pm 0.2{ }^{\circ} \mathrm{C}$. It should be noted that IR temperature calibrations were different for each test due to the optical alignment even though linear relationships are still maintained. Therefore, on-line calibration is needed in order to get accurate temperature measurement.
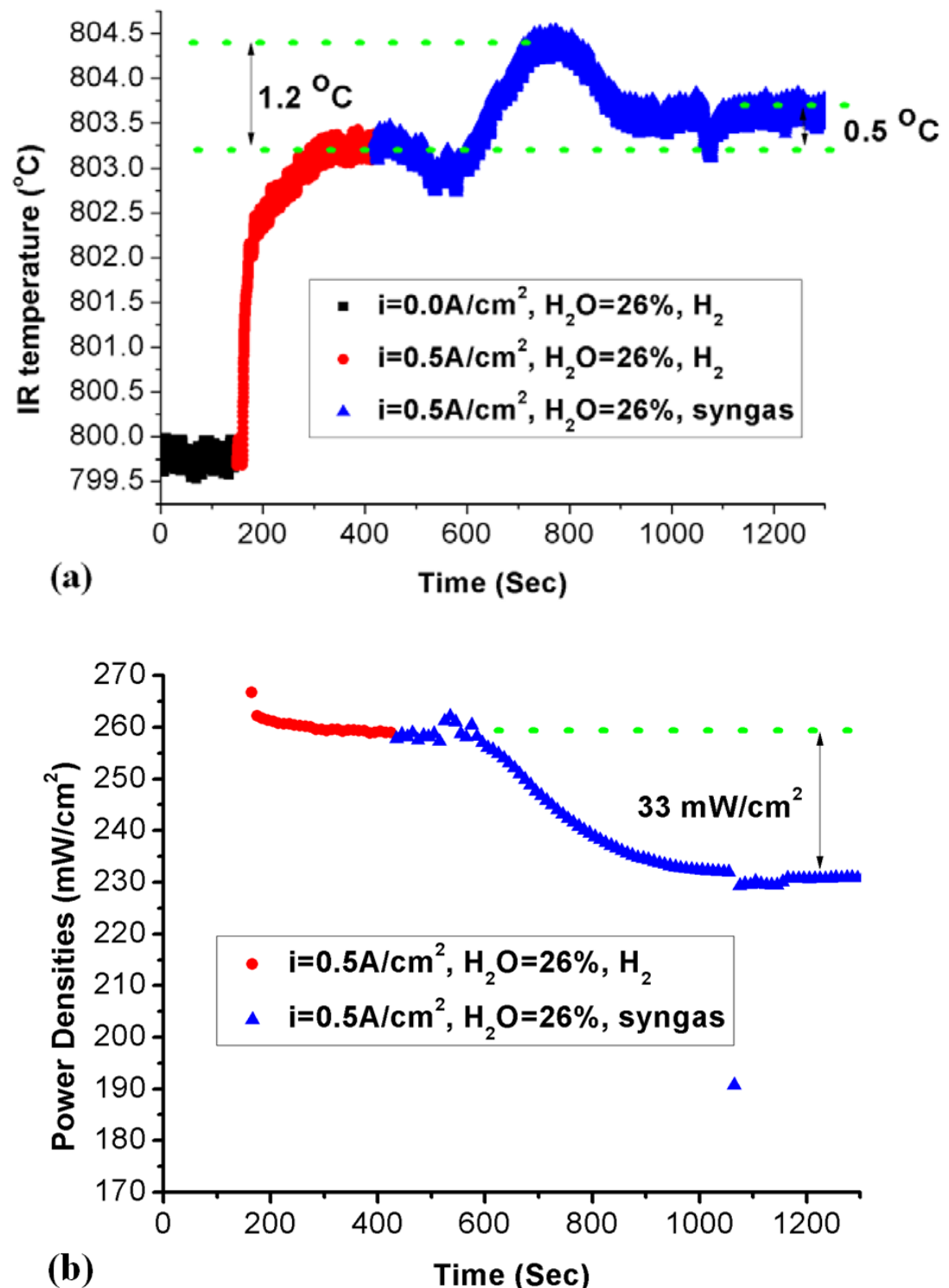

Figure 3. 15 (a) Transient surface IR Emission and (b) Power densities measurement during switch from $100 \mathrm{sccm} \mathrm{H}_{2} / 3$ vol. \% $\mathrm{H}_{2} \mathrm{O}$ to clean syngas at $\mathrm{i}=0.5$ $\mathrm{A} / \mathbf{c m}^{2}$ 
As already mentioned, this technique has high spatial resolution and fast acquisition time to study the dynamic phenomena, which we can utilized to monitoring the surface temperature variation during the switching of fuel gas. In the present work, the surface temperature change is monitored while the fuel gas supply was switched from hydrogen fuel to simulated clean coal syngas. To avoid damage of button cell, SOFC was operated at its open circuit potential OCV when the humidifier was heated from room temperature to $66^{\circ} \mathrm{C}$ to increase water vapor concentration from $3 \%$ to $26 \%$ in fuel gas. Once the cell was stabilized, operating current density $0.5 \mathrm{~A} / \mathrm{cm}^{2}$ was applied to the button cell. The corresponding surface temperature increase is plotted in Figure 3.15 (a).

As the fuel gas was switched to simulated coal syngas, the power density fluctuated initially and then stabilizes to a steady state with $33 \mathrm{~mW} / \mathrm{cm}^{2}$ power density drop, as shown in Figure 3.15 (b). Due to the change of fuel gas composition, $\mathrm{H} / \mathrm{C}$ and $\mathrm{O} / \mathrm{C}$ atom ratios were decreased and caused the slowdown of reaction rate, especially near the active anode/electrolyte interface and the concentration polarization becomes significant [111, 112]. Thus the performance of button cell under syngas is lower and more excess heat is generated, as shown in Figure 3.15(b).

To investigate the effect of polarization on cell electrode reaction, in-situ surface IR emission measurement was also carried out as a function of loading current densities under different cell operating conditions. Similar trends were obtained under hydrogen (w/o 3 vol. $\% \mathrm{H}_{2} \mathrm{O}$ ) and simulated clean coal syngas $\left(30 \% \mathrm{H}_{2}, 23 \% \mathrm{CO}, 21 \% \mathrm{CO}_{2}, 26 \%\right.$ $\mathrm{H}_{2} \mathrm{O}$ ). Figure 3.16 shows the transient variation of surface IR emission with the current density in steps, from 0 to $0.8 \mathrm{~A} / \mathrm{cm}^{2}$ under $100 \mathrm{sccm} \mathrm{H}_{2} / 3$ vol. $\% \mathrm{H}_{2} \mathrm{O}$, while the results under clean syngas is demonstrated in Figure 3.17 . As shown in Figure 3.16(a), cell surface temperature increases with increase in current density and it takes about 20 to 60 seconds to reach steady state temperature depending on the applied current density. It is illustrated from Figure 3.16(b) that the final steady state surface temperature is 
independent of the intermediate current steps and only depends on the final current density (e.g. $0.8 \mathrm{~A} / \mathrm{cm}^{2}$ ) but it takes less time to reach the steady state temperature when current is applied in larger steps. Figure 3.16(b) also shows the corresponding cell performance as loading current densities. The cell performance plays an important role in the surface temperature variation.
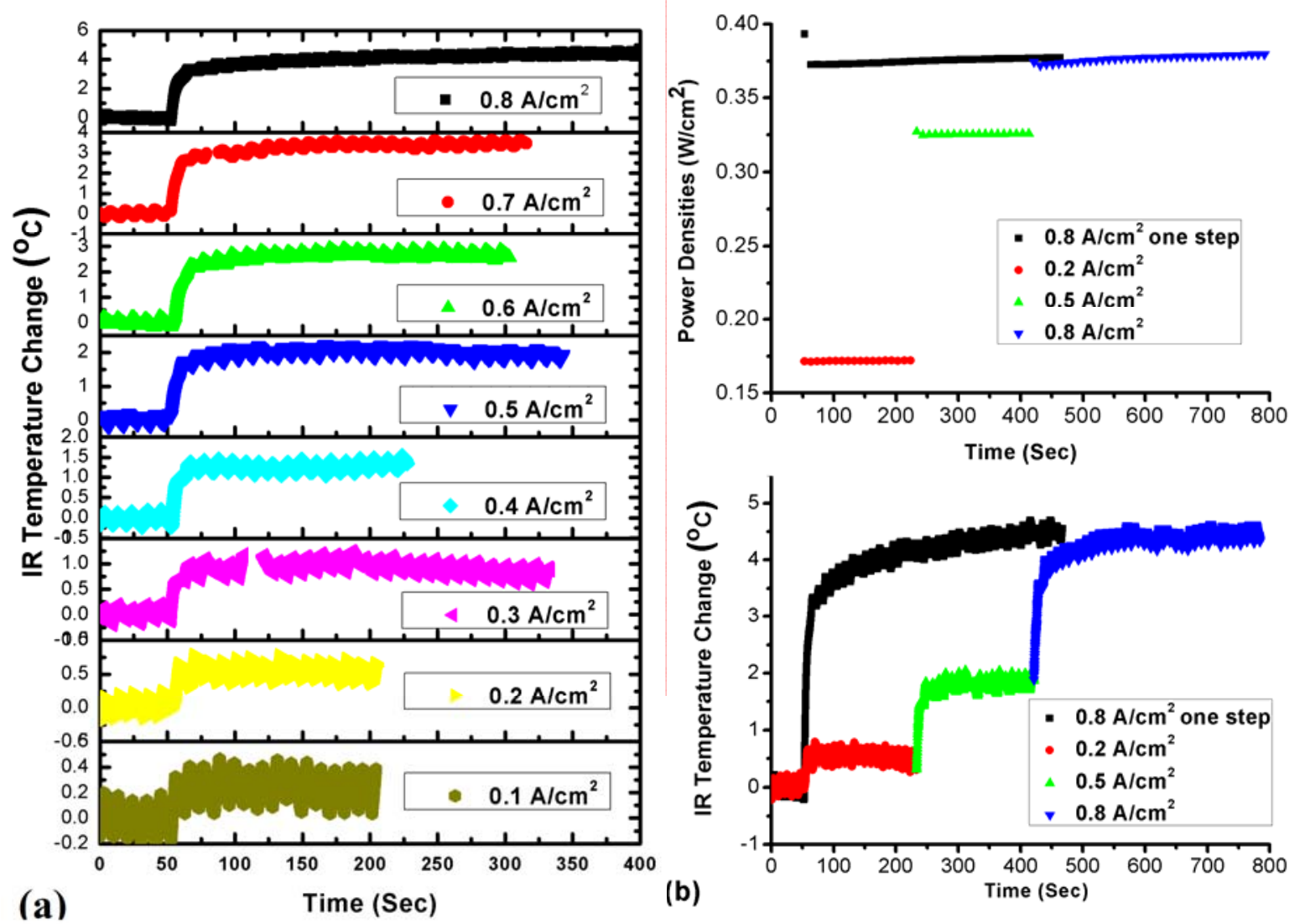

Figure 3. 16 (a) Transient Surface IR Emission Variations of Button Cell at Different Loading Current Densities under 100 sccm $\mathrm{H}_{2} / 3$ vol.\% $\mathrm{H}_{2} \mathrm{O}$; (b) Transient Surface IR Emission Variations at Different Loading Current Densities Interval under $100 \mathrm{sccm} \mathrm{H}_{2} / 3$ vol.\% $\mathrm{H}_{2} \mathrm{O}$, and Corresponding Power Densities History of Button Cell (Surface temperature $\mathrm{T}=799.65^{\circ} \mathrm{C}$ at $\mathrm{i}=0 \mathrm{~A} / \mathrm{cm}^{2}$ ) 

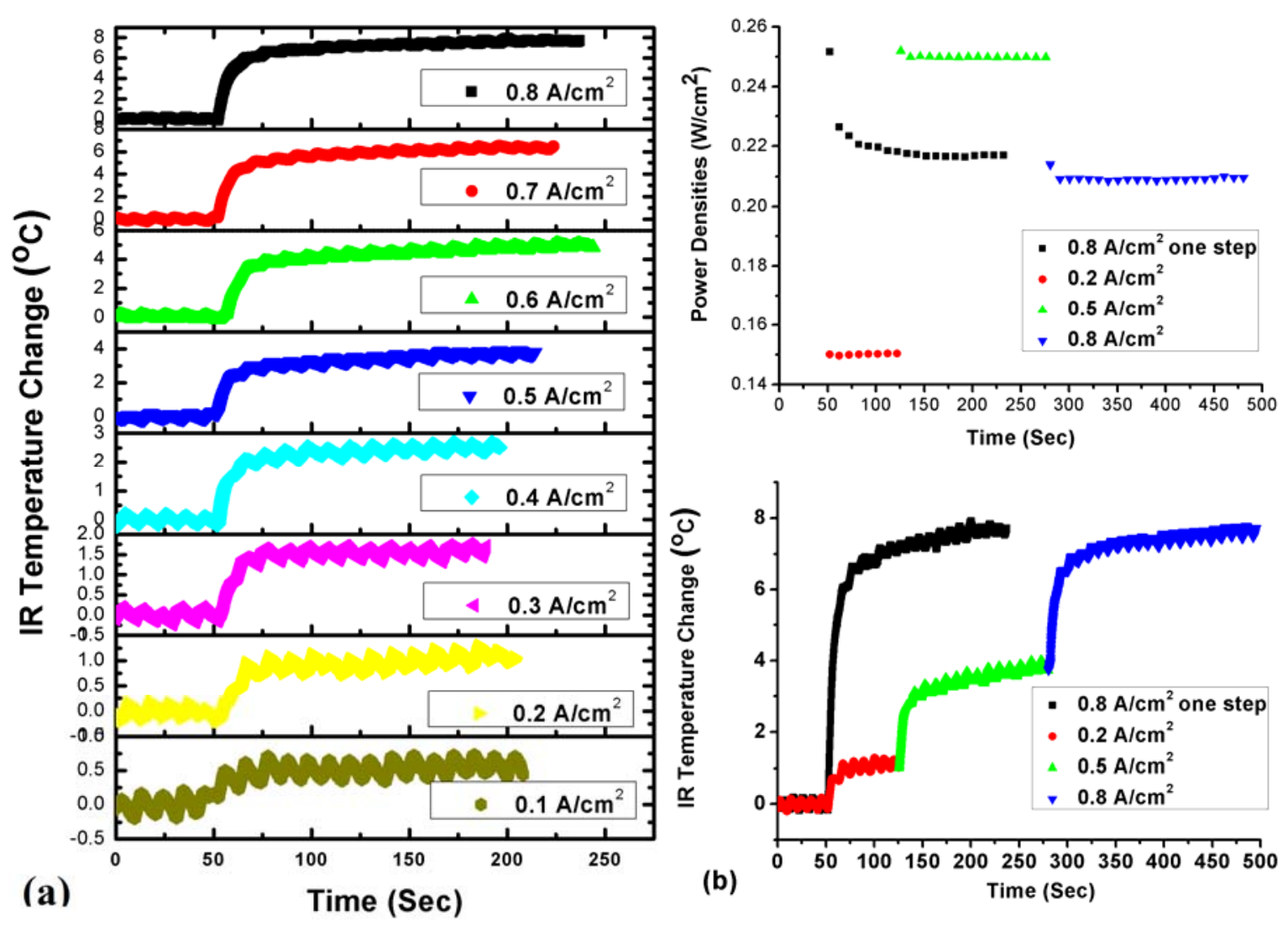

Figure 3. 17 (a) Transient Surface IR Emission Variations of Button Cell at Different Loading Current Densities under 100 sccm clean syngas; (b) Transient Surface IR Emission Variations at Different Loading Current Densities Interval under 100 sccm clean syngas, and Corresponding Power Densities History of Button Cell (Surface temperature $\mathrm{T}=800.56{ }^{\circ} \mathrm{C}$ at $\mathrm{i}=\mathbf{0 ~ A} / \mathrm{cm}^{2}$ ) 

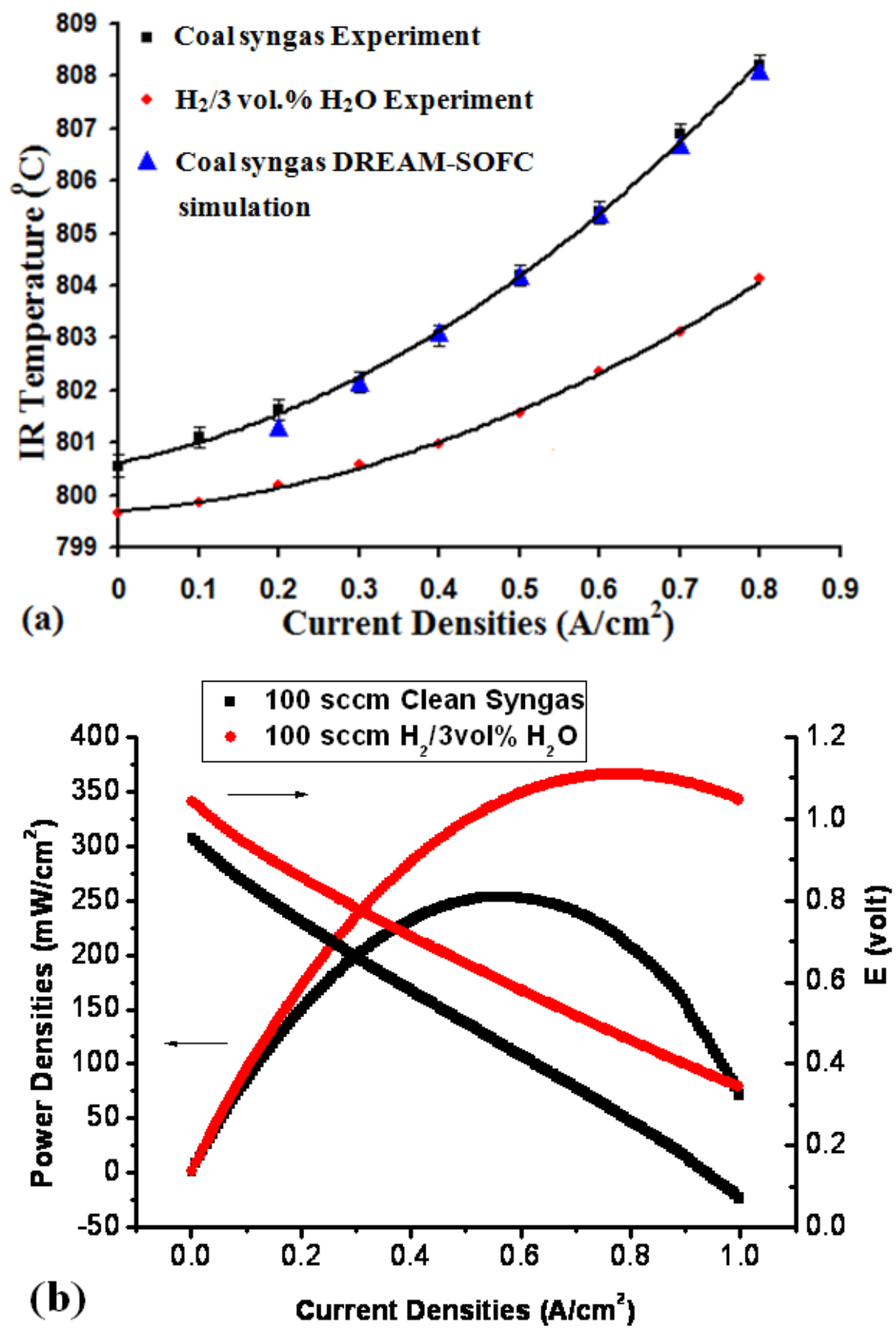

Figure 3. 18 (a) Surface IR emission comparisons between $100 \mathrm{sccm} \mathrm{H}_{2} / 3$ vol.\% $\mathrm{H}_{2} \mathrm{O}$ and simulated coal syngas at different loading current densities, (b) Corresponding polarization curves of SOFC 


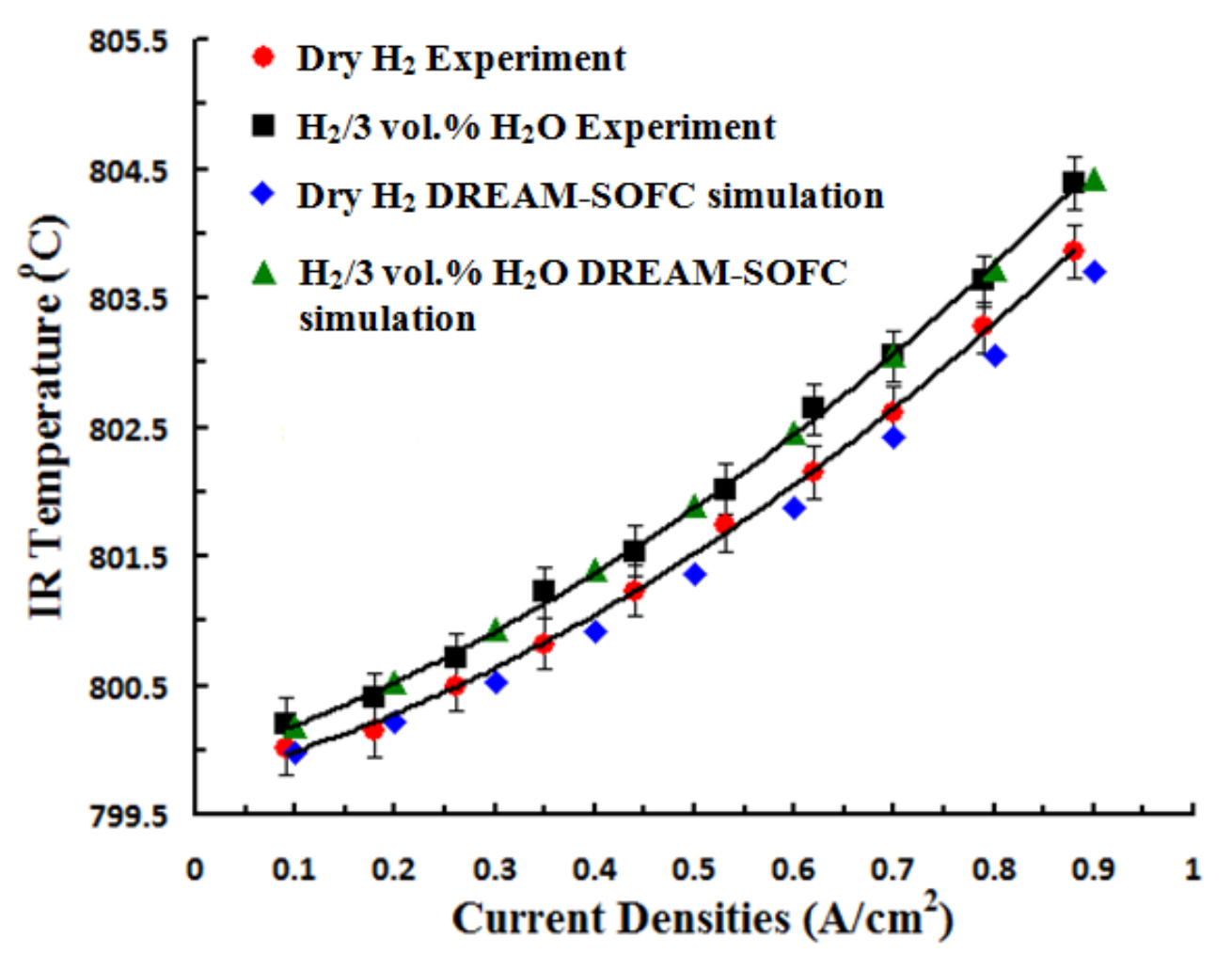

Figure 3. 19 Surface IR emission comparisons between $100 \mathrm{sccm} \mathrm{H}_{2}$ w/o 3 vol. \% $\mathrm{H}_{2} \mathrm{O}$ at different loading current densities

The changes of steady-state button cell surface temperature are plotted against loading current densities and the comparisons under different cell operating conditions are illustrated in Figure 3.18 and Figure 3.19. It should be noted that the difference of surface temperature under same condition of $\mathrm{H}_{2} / 3$ vol.\% $\mathrm{H}_{2} \mathrm{O}$ is resulted from the different configuration of SOFC button cells tested in these two studies. However, for each test, the result is consistent, and the surface temperature variation is strongly related to the cell performance. As shown, the relation between surface temperature and current density is found to be nonlinear. The surface temperature variation is shown to be the highest under simulated coal syngas, while the one under moist hydrogen fuel is a little higher than under dry hydrogen condition. This is due to different heat generation under different cell operating conditions such as more exothermic water gas shift reaction under coal syngas. Besides, the heat generation within a cell increases with the current drawn 
out of it, due to the fuel cell internal resistance. As illustrated in Figure 3.18(b), the cell is less efficient under simulated coal syngas than under hydrogen thus generates more excess heat at the same operating current density. Also shown in figures are numerical data from DREAM-SOFC $[113,114]$ (a three dimensional computational fluid dynamics solver developed by Dr. Celik's research group at West Virginia University). The experimental data is used to assess the validity of the numerical model. From the comparison between experimental and simulation results, it is found that the major source of the surface temperature rise is entropic heating from fuel oxidation and a minor source is ohmic heating. It also demonstrated that the water gas shift reaction provides negligible contributions to the surface temperature variations of SOFCs operating under coal syngas.

\subsection{Conclusions}

A novel experimental technique has been developed and applied for in-situ SOFC investigation. The experimental setup consists of a NexTech Probostat ${ }^{\mathrm{TM}} \mathrm{SOFC}$ button cell test apparatus integrated with Sagnac interferometric optical setup and infrared thermometer. Notable advantages of this technique are (i) the optical window does not affect the fringe formation, (ii) half wavelength measurement sensitivity, (iii) immune to temperature fluctuation and (iv) immune to vibration, making this optical technology suitable for in-situ, on-line measurement. It is capable of electrode surface deformation and temperature measurement along with the standard cell electrochemical measurements.

The SOFC button cell exposed to hydrogen (w/o steam) or simulated coal syngas is tested under operating conditions. The surface deformation is measured at room temperature and operating temperature to estimate the mechanical properties of anode materials. The cell surface transient temperature is also monitored as a function of loaded current density to investigate the effect of polarization on cell electrode reaction. This reliable technique is able to provide useful experimental data to validate and develop the SOFC numerical models, including both electrochemical and structural simulations. 


\section{Chapter 4: Characterization of $\mathrm{PH}_{3}$ Poisoning Effects on $\mathrm{Ni}-\mathrm{YSZ}$ anode}

\subsection{Introduction}

Solid Oxide Fuel Cell (SOFC) is a promising candidate for direct utilization of coal syngas for future clean power generation. Currently, Nickel-Yttria Stabilized Zirconia (Ni-YSZ) is the most widely used anode material currently due to its excellent performance in hydrogen and simulated coal syngas. However, coal syngas is known to be a 'dirty' gas containing a wide range of contaminants in addition to hydrogen, carbon monoxide, methane, carbon dioxide and nitrogen, as summarized in Chapter 2. The electrochemical performance and materials properties of SOFC anode are affected when exposed to certain contaminants in the syngas. Among the contaminants in the coal syngas, phosphorus is one of the most harmful elements to the Ni-YSZ anode potentially, as reviewed previously.

In the present work, the poisoning effects of $\mathrm{PH}_{3}$ on the electrochemical behavior of the Ni-YSZ anode will be reported, and the degradation mechanism and surface IR emission variations will be discussed as well. The relationship of the SOFC performance with some key parameters such as potential bias, steam and contaminant concentration is studied and the anode material phase transfer and microstructure are investigated. Two sets of experiments will be carried out in order to address those parameters. The first set of results provides the information about the Ni-YSZ material phase and microstructure changes under pure chemical exposure of $\mathrm{PH}_{3}$ without loaded electrical potential bias. The second one is the detail investigation of the combined effects of $\mathrm{PH}_{3}$ and steam concentration on the degradation behaviors under SOFC operating conditions. In addition, the thermodynamic analysis would be carried to help understanding the experiment results. 


\subsection{Experimental Approach}

Commercial anode-supported SOFC button cells, manufactured by Materials and Systems Research Inc. (MSRI), were tested in this study. The MSRI cell fabrication procedure and material parameters are described by Zhao, F., et al. [117]. Each button cell was about $3.0 \mathrm{~cm}$ in diameter with an anode composed of a $1 \mathrm{~mm}$ thick Ni-8YSZ support structure and a $25 \mu \mathrm{m}$ thick interlayer of a highly catalytic Ni-8YSZ mixture. The electrolyte (8YSZ) was $25 \mu \mathrm{m}$ thick and cathode $\left(2.27 \mathrm{~cm}^{2}\right.$ active area) was composed of a $25 \mu \mathrm{m}$ thick $\mathrm{La}_{0.8} \mathrm{Sr}_{0.2} \mathrm{MnO}_{3}$ (LSM)-8YSZ interlayer and a $25 \mu \mathrm{m}$ thick currentcollection layer of LSM. An Au current collection mesh was attached to the anode using nickel contact paste. Similarly, a Pt mesh was attached to the cathode using platinum paste. Silver current cables and voltage taps were spot welded onto opposite sides of each current collection mesh. For comparison, a pure Ni metal plate with same dimension is also tested.

The button cell was mounted inside the NexTech Probostat ${ }^{\mathrm{TM}}$ button cell test apparatus, which is shown in Figure 3.5 and 3.7, using AREMCO-516 high temperature cement. A PhotriX infrared (IR) pyrometer and a thermocouple placed adjacent to the button cell were applied to monitor the temperature, respectively. Alicat ${ }^{\mathrm{TM}}$ mass flow controllers (MFCs) were used to control fuel/air flow rates, pressure and fuel compositions. A temperature-controlled humidifier was used to control the water content of fuel gas supplied to the anode side.

The procedure of SOFC button cell treatments is shown in Figure 4.1. The button cell was heated from room temperature to $750^{\circ} \mathrm{C}$ at the rate of $1{ }^{\circ} \mathrm{C} / \mathrm{min}$ while $100 \mathrm{sccm}$ (standard cubic centimeter per minute) $\mathrm{N}_{2}$ is introduced to the anode and $250 \mathrm{sccm}$ air for the cathode, respectively. And then reduction of anode material was carried out at $750{ }^{\circ} \mathrm{C}$, while the open circuit potential was monitored. During reduction, the button cell was exposed to $10 \% \mathrm{H}_{2}$ for 2 hours, $50 \% \mathrm{H}_{2}$ for 2 hours, and finally $100 \%$ hydrogen with 
load applied $0.5 \mathrm{~A} / \mathrm{cm}^{2}$ after about 10 minutes and lasting overnight. After complete anode reduction, the air flow rate for the cathode was increased to $300 \mathrm{sccm}$, and the IR temperature calibration was carried out with $5^{\circ} \mathrm{C}$ steps, from $750^{\circ} \mathrm{C}$ to $800^{\circ} \mathrm{C}$. At discrete temperature steps, data was recorded from IR Pyrometer and an embedded thermocouple close to the button cell at steady state.

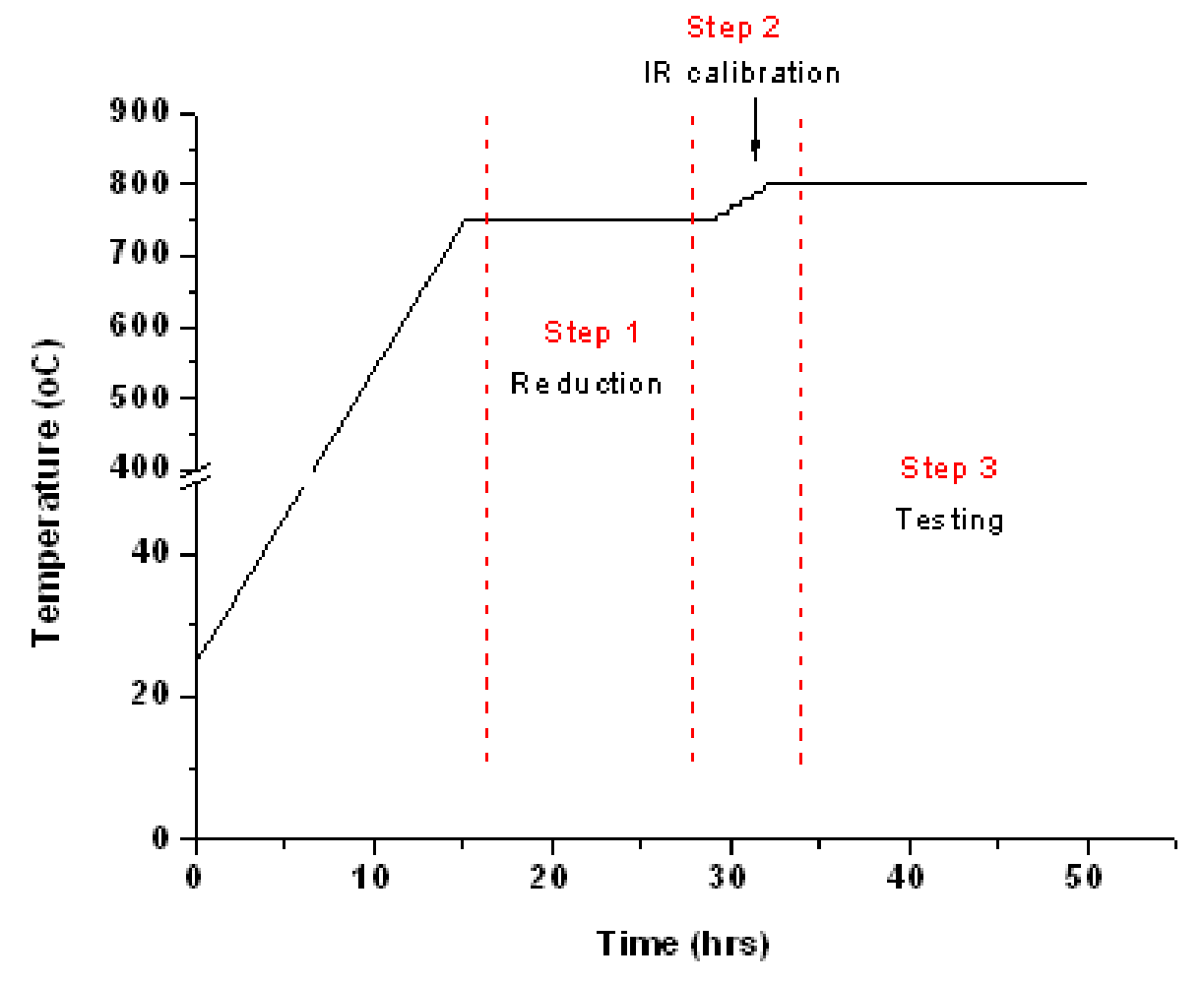

Figure 4. 1 Procedures of SOFC Button Cell Treatment and IR Calibration

In the present work, comparison tests were conducted in which the button cells were exposed to ppm level of $\mathrm{PH}_{3}$ in dry and moist hydrogen under open circuit voltage (OCV) and loading conditions to study $\mathrm{PH}_{3}$ poisoning effect on SOFC performance at $800^{\circ} \mathrm{C}$. The $\mathrm{PH}_{3}$ contaminant was fed with a $1000 \mathrm{ppm} \mathrm{PH}_{3} / \mathrm{N}_{2}$ gas mixture by the mass flow controllers. A humidity bottle was employed to achieve the desired water vapor partial pressure. Electrochemical performances were measured using a Solartron electrochemical 
interface (SI 1287) and Solartron impedance analyzer (SI 1260). The impedance spectra were collected with $\mathrm{AC}$ amplitude of $10 \mathrm{mV}$ at frequencies ranging from $1 \mathrm{MHz}$ to 0.1 $\mathrm{Hz}$.

Concurrently, PhotriX infrared (IR) pyrometer is integrated to monitor anode surface temperature of operational SOFC. To investigate the polarization effect on electrode reaction, button cell surface temperature and cell performance were monitored while changing applied current, as illustrated in Figure 4.2. In phase 1, different current densities were applied and the transient surface temperature and time to reach steady state condition was monitored and recorded. In phase 2 , the comparison of surface temperature was conducted under the same applied current density but through different steps. The surface temperature variation was also recorded during switching fuel gases and $\mathrm{PH}_{3}$ attacking.

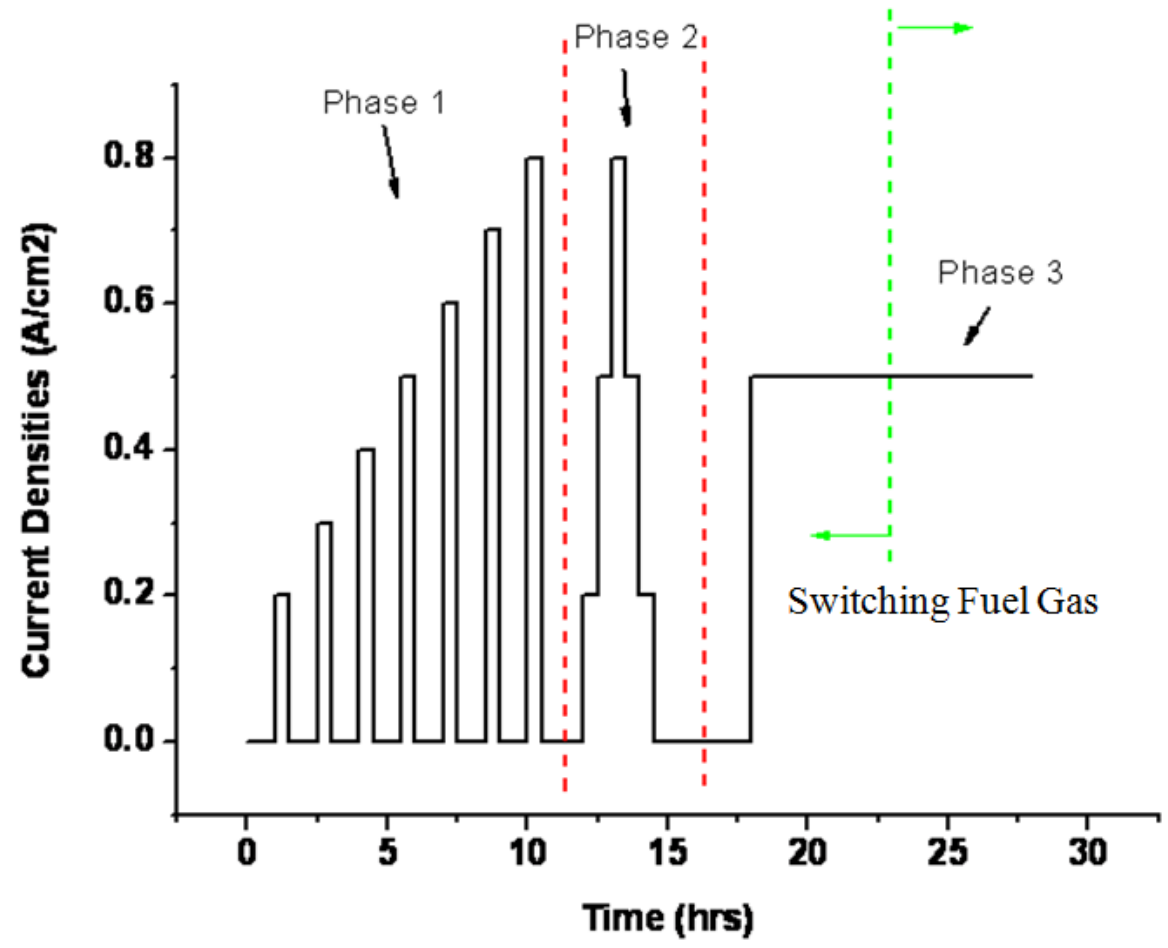

Figure 4. 2 Procedures of Applying Current Densities 
The morphology of the Ni-YSZ anode was examined with Hitachi S-4700 scanning Electron Microscope (SEM). The crystal structure of the anode was determined with Panalytical X-ray diffractometer (XRD) equipped with a thin film stage. The chemical status and chemical composition of the anode was characterized with Omicron ESCA PROBE X-ray photoelectron spectroscopy (XPS). XPS was performed with a monochromatic $\mathrm{Al} \mathrm{K} \alpha$ radiation $(1486.6 \mathrm{eV})$ with an operating power of $300 \mathrm{~W}$.

\subsection{Results and Discussion}

\subsubsection{Electrochemical Measurements}

Irreversible degradation of the SOFC anode has been reported due to the phosphorous exposure $[9-15,17,56,58-64,118]$. However, there are few studies focused on the relationship among the phosphorus compounds, steam in fuel and potential bias. In the present work, comparison tests were conducted in which the button cells were exposed to ppm level of $\mathrm{PH}_{3}$ in dry and moist hydrogen under open circuit voltage (OCV) and loading conditions to study $\mathrm{PH}_{3}$ poisoning effect on SOFC performance at $800^{\circ} \mathrm{C}$.

Figure 4.3 shows the variation of SOFC power density history at constant loading current density of $0.7 \mathrm{~A} / \mathrm{cm}^{2}$ over time. In this process called variation test of $\mathrm{PH}_{3}$ exposure, the cell was initially exposed to dry hydrogen gas and then $10 \mathrm{ppm}$ of $\mathrm{PH}_{3}$ was injected into the fuel gas for $48 \mathrm{hrs}$. It can be seen from Figure 4.3 that the cell power density remained constant during exposure to $\mathrm{PH}_{3}$ with dry $\mathrm{H}_{2}$. The cell performance did not show degradation until the steam was introduced into the fuel gas. As shown in Figure 4.3, the power density of button cell decreased gradually over time, e.g. 0.12 $\mathrm{mW} / \mathrm{cm}^{2}$ per hour degradation under $\mathrm{H}_{2} / 3$ vol. $\% \mathrm{H}_{2} \mathrm{O}$ with $10 \mathrm{ppm} \mathrm{PH}_{3}$. It also illustrated that the cell performance degradation was more severe under higher steam content in the $\mathrm{PH}_{3}$-containing fuel gas. 


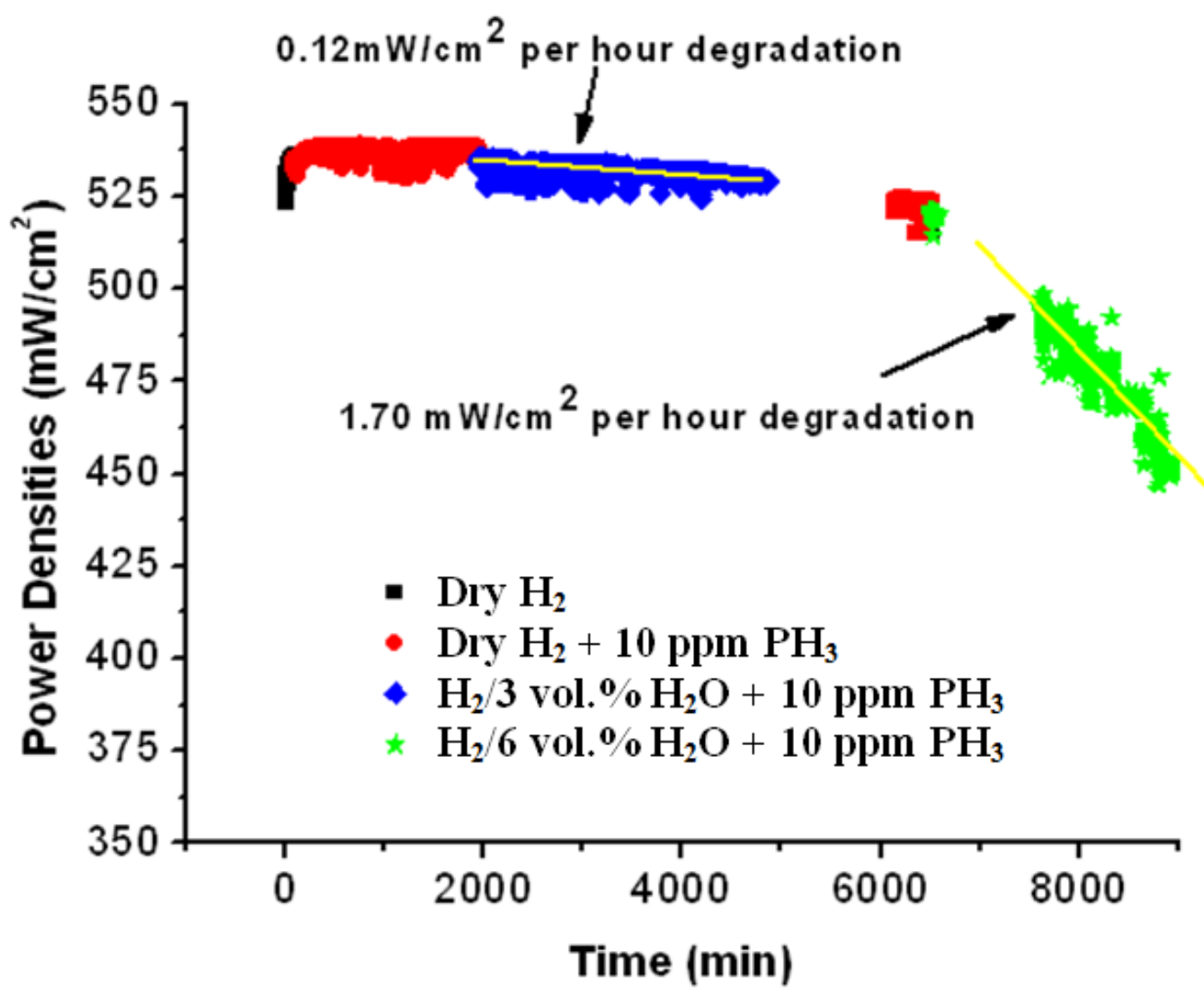

Figure 4. 3 Variation of SOFC power density under different testing conditions at $i$ $=0.7 \mathrm{~A} / \mathbf{c m}^{2}$

The electrochemical impedance data were also obtained at the open circuit condition. Two arcs were observed in the Nyquist plots of impedance (Figure 4.4). The Z'-intercept of the high frequency arc yielded the ohmic polarization resistance of the cell. It exhibited a low value of $0.2 \Omega \cdot \mathrm{cm}^{2}$ and showed little shift during the successive gas exposures. The high frequency arc is attributed to the impedance of the charge transfer processed occurring at the electrolyte/electrode interface and at the Ni/YSZ interface. The low frequency arc is associated with the bulk capacitance and the chemical processes including adsorption, surface migration, bulk migration and other mechanistic steps. It is illustrated that the polarization resistance (the total arc width) increased with time during 
exposure to $\mathrm{PH}_{3}$-containing moist hydrogen fuel gas. The more moist content, the faster polarization resistance increases. This increase suggests that the cell was undergoing degradation, and the poisoning effect of $\mathrm{PH}_{3}$ was sincerely associated with the content of steam in the fuel gas. Figure 4.5 shows the corresponding IV-curves and power densities under different conditions, which are consistent with the cell degradation indicated in the Figure 4.3 and Figure 4.4.

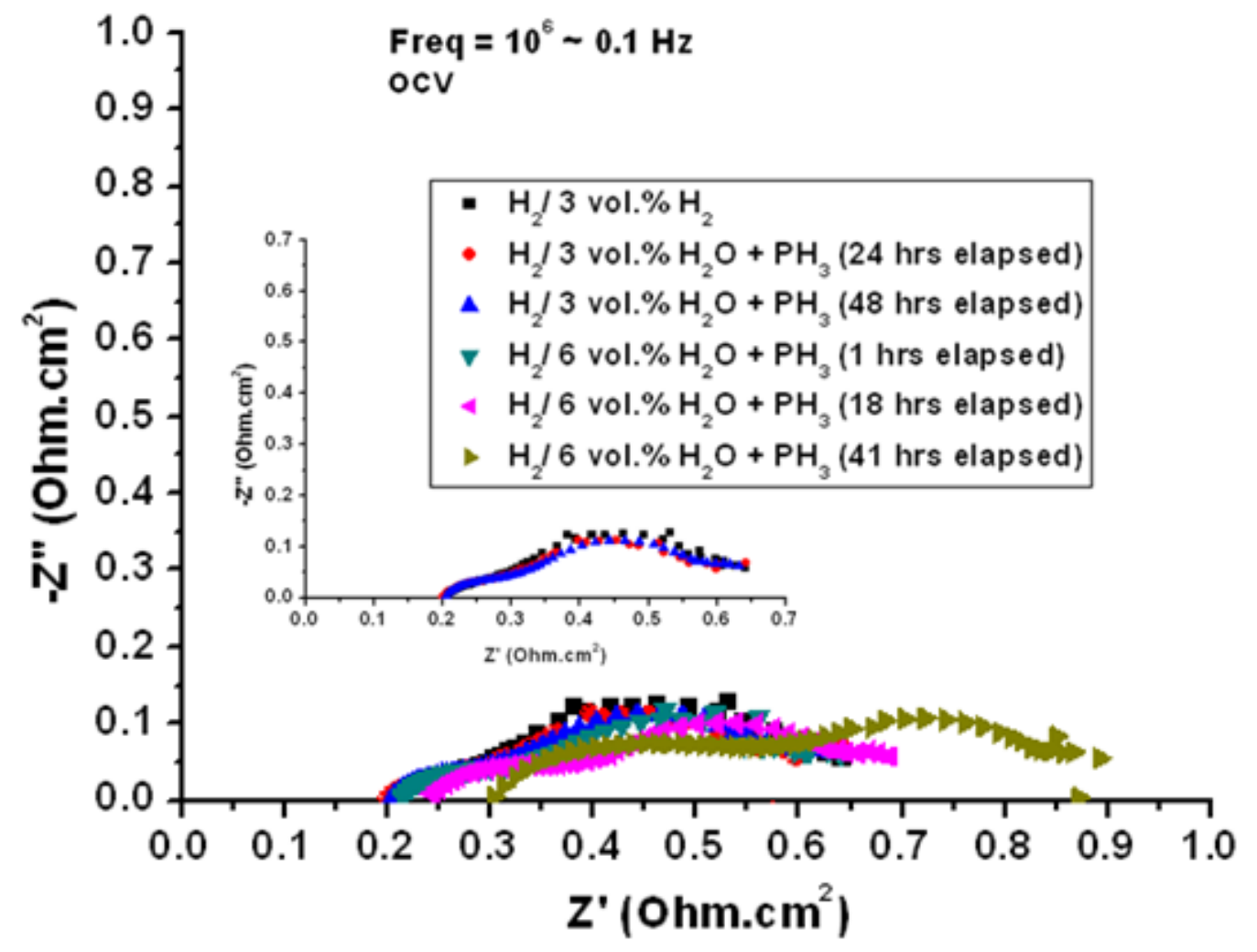

Figure 4. 4 Corresponding impedance plots for SOFC operating under the open circuit voltage condition (OCV) at $800{ }^{\circ} \mathrm{C}$

To investigate these phenomena and further understand the secondary phase 
formation mechanisms, long-term $\mathrm{PH}_{3}$ exposure tests were carried out under dry and wet hydrogen conditions w/o loading potential bias.

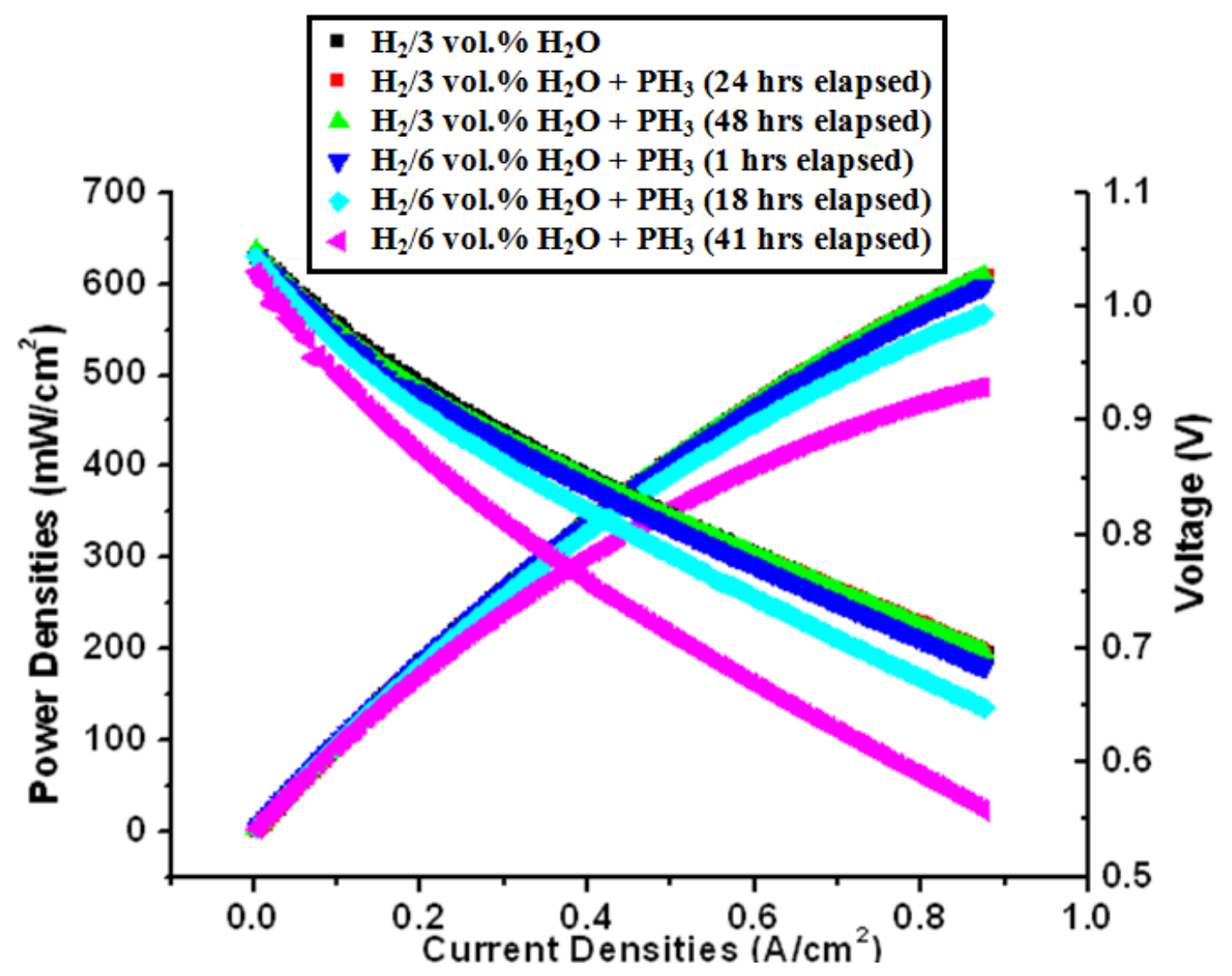

Figure 4. 5 Corresponding I-V curves of SOFC operating at $800{ }^{\circ} \mathrm{C}$

As illustrated in Figure 4.6, the button cell was subjected to dry hydrogen with 10 ppm $\mathrm{PH}_{3}$ under applied current density of $0.6 \mathrm{~A} / \mathrm{cm}^{2}$ and the long term tests were carried out. The cell performance remained stable in the first 4 days under exposure of dry hydrogen $/ \mathrm{PH}_{3}$. For the next 6 days, the cell performance degraded slowly at a rate of 0.43 $\mathrm{mW} / \mathrm{cm}^{2}$ per hour. After that, the cell failed sharply within one day due to the cracking of button cell, which will be discussed in the later section in details. 


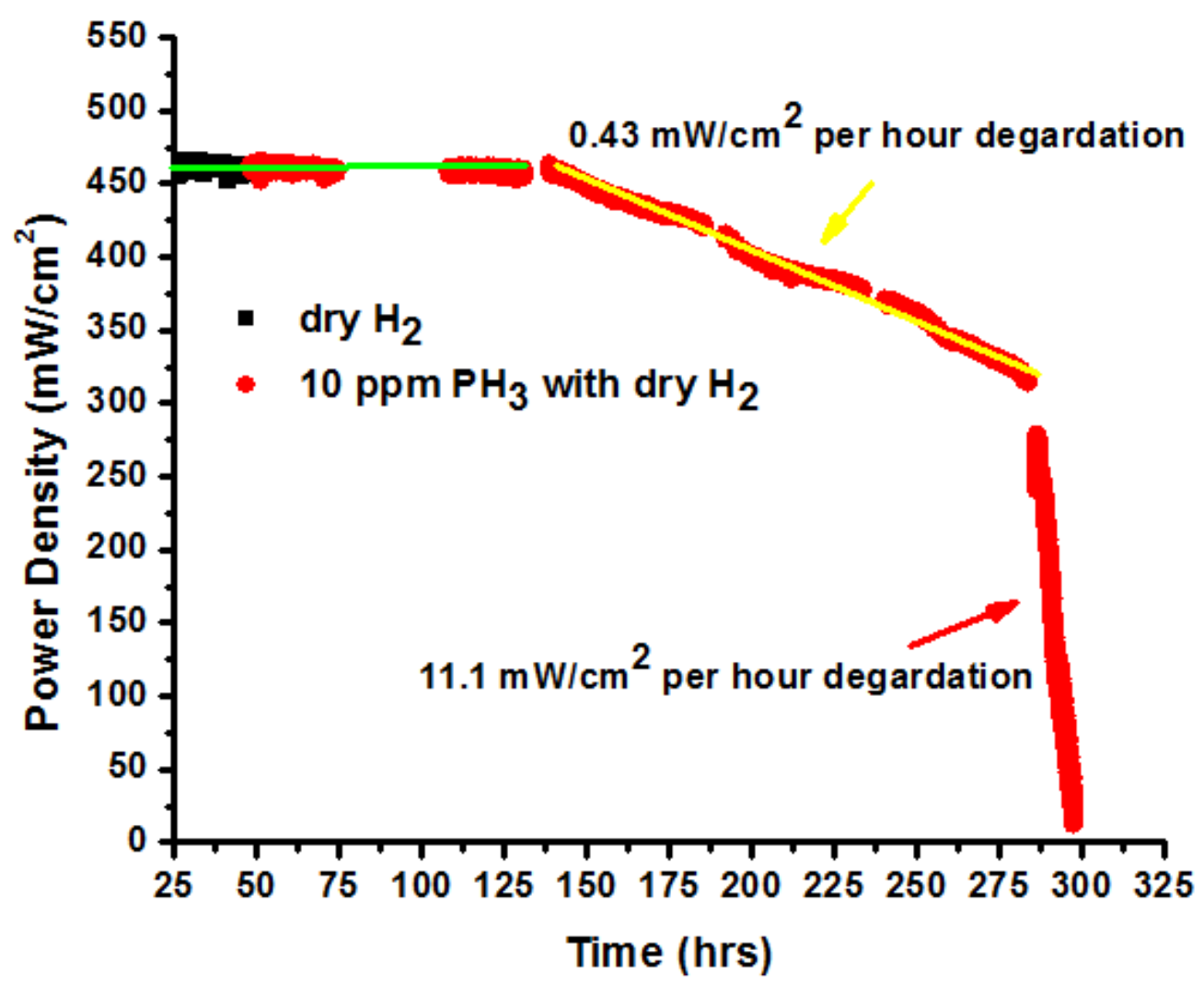

Figure 4. 6 Variation of SOFC power density under dry $\mathrm{PH}_{3}$ contained Hydrogen at $\mathrm{i}=0.6 \mathrm{~A} / \mathrm{cm}^{2}$

The corresponding EIS and IV curves measurements were shown in Figure 4.7 and 4.8. The electrochemical impedance data were obtained at operating conditions (DC bias $=0.3 \mathrm{~V})$. IV curves over time are consistent with the performance degradation history. Two arcs were observed in the Nyquist plots of impedance in Figure 4.7. The intercept with the real axis at high frequency is the ohmic resistance of the cell. It exhibited a low value of about $0.25 \Omega \cdot \mathrm{cm}^{2}$ and showed little shift during the successive gas exposures (64\% increases for $240 \mathrm{hrs}$ exposure). It is also found that the polarization resistance (the total arc width) increased with time during exposure to $\mathrm{PH}_{3}$-containing dry hydrogen fuel gas. When exposed to $10 \mathrm{ppm} \mathrm{PH}_{3}$, the polarization resistance increased $267 \%$ in $240 \mathrm{hrs}$, which indicated the dominant cell performance degradation due to $\mathrm{PH}_{3}$ effects. 


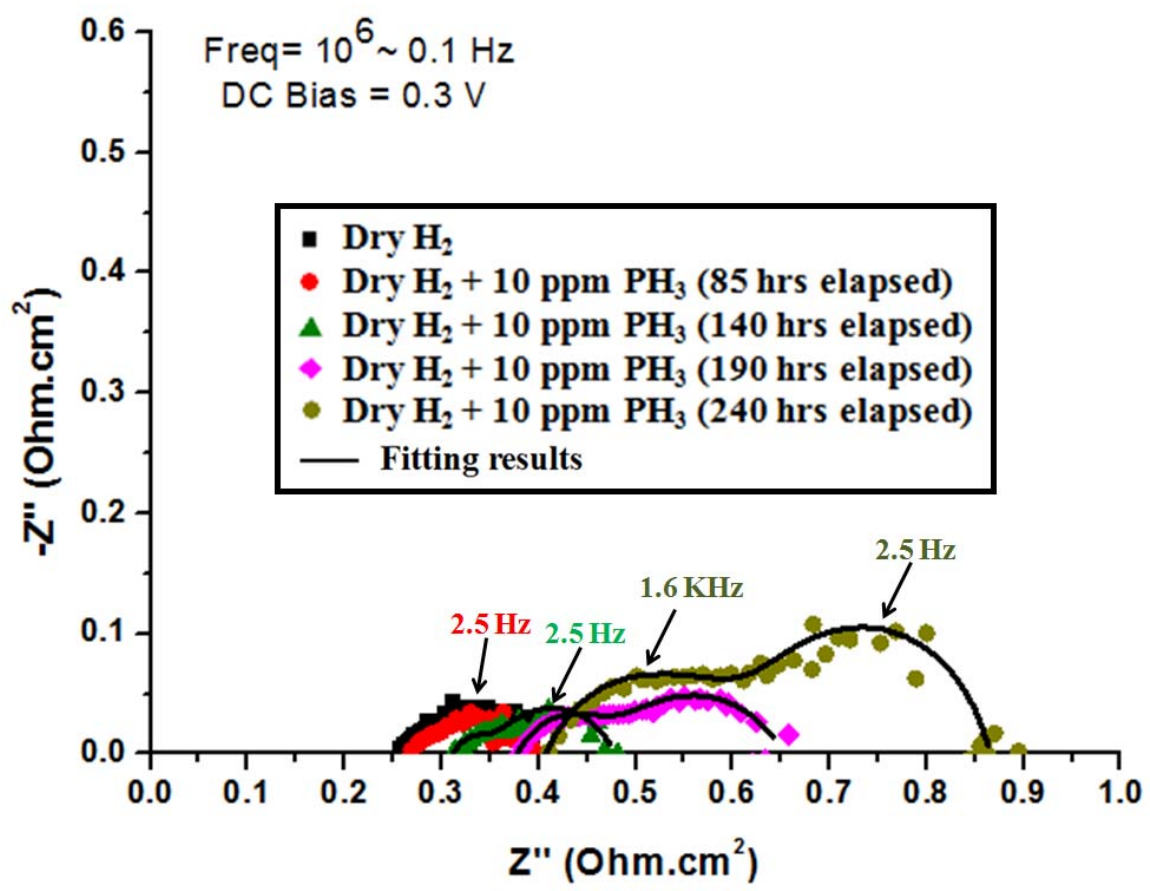

Figure 4. 7 Corresponding Impedance plots for SOFC operating at $0.3 \mathrm{~V}$ potential bias

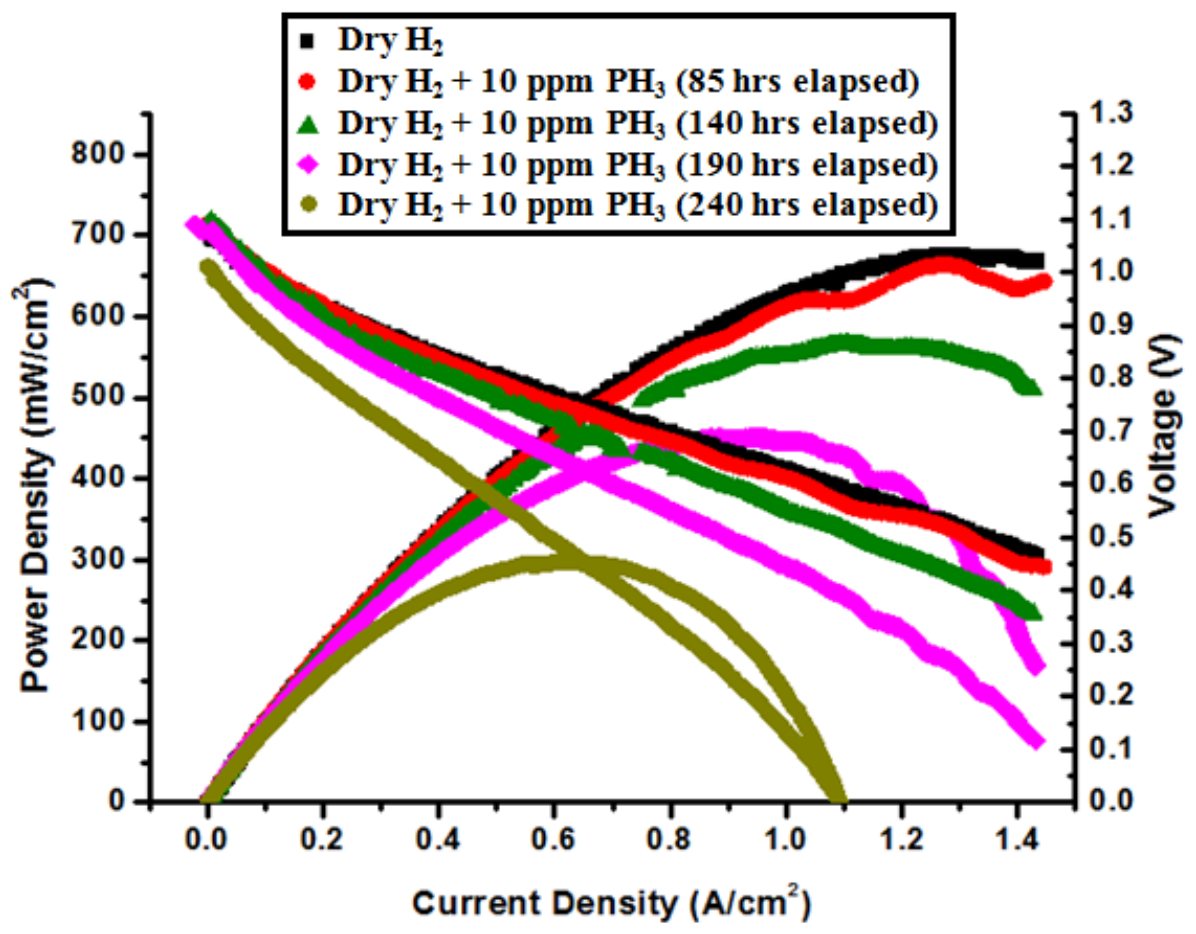

Figure 4. 8 Corresponding I-V curves of SOFC operating at $800{ }^{\circ} \mathrm{C}$ 
To further elucidate the experimental data, the equivalent circuits and fitting results were given in Figure 4.9. In this equivalent circuit model, the inductance $(L)$ is associated with either the long $\mathrm{Ag} / \mathrm{Pt}$ current-voltage probe or the high-frequency phase shift of the electrochemical equipment. The ohmic resistance $\left(R_{\Omega}\right)$ is attributed to the electrolyte, electrodes and the connection wires. $\mathrm{C}$ represents the geometrical capacitance. The ordered pairs $\left(R_{H}, \Phi_{H}\right)$ and $\left(R_{L}, \Phi_{L}\right)$ correspond to the high- and low-frequency arcs, respectively [1, 126-128]. The symbol $\Phi$ denoted a double-layer constant phase element. The impedance, $Z_{\mathrm{CPE}}$, is defined by:

$$
Z_{C P E}=1 / Y(j w)^{n}
$$

Where $\mathrm{Y}$ is the pseudo-capacitance, $\omega$ is radial frequency and $\mathrm{n}$ is the exponent constant. For $\mathrm{n}=1$, the $\Phi$ element reduces to an ideal capacitor with capacitance $\mathrm{Y}$, and when $\mathrm{n}=$ 0 , the $\Phi$ element reduces to a simple resistor with admittance Y [129]. The highfrequency arc is related to the charge transfer at the electrode/electrolyte interface from the movement of oxygen ions $[126,128]$. The low-frequency arc corresponds to gaseous diffusion within the anode $[1,126,128]$. The low-frequency arc was larger than the highfrequency arc, indicating gas diffusion processes probably limited the electrode reaction. The values of the circuit elements at the different conditions are listed and compared in Table 4.1.

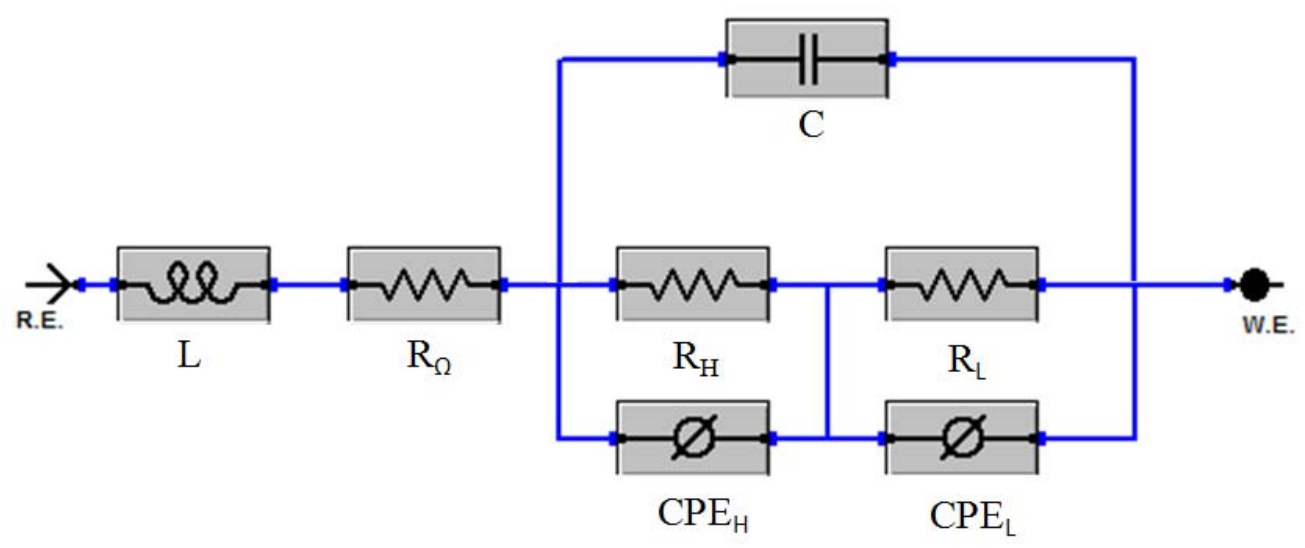

Figure 4. 9 Equivalent circuit models of the impedance spectra 
Table 4. 1 Results of fitting EIS at the different conditions

\begin{tabular}{|c|c|c|c|c|c|c|c|c|c|c|c|}
\hline \multirow{2}{*}{ Elements } & \multicolumn{5}{|c|}{ Dry $\mathrm{H}_{2}$ w/o 10 ppm $\mathrm{PH}_{3}$ (Figure 4.7) } & \multicolumn{6}{|c|}{$\mathrm{H}_{2} / 3$ vol. $\% \mathrm{H}_{2} \mathrm{O} / 10 \mathrm{ppm} \mathrm{PH}_{3}$ (Figure 4.11) } \\
\hline & $\mathrm{H}_{2}$ & $\begin{array}{l}\mathrm{H}_{2} / \mathrm{PH}_{3} \\
(85 \mathrm{hrs})\end{array}$ & $\begin{array}{c}\mathrm{H}_{2} / \mathrm{PH}_{3} \\
(140 \\
\mathrm{hrs}) \\
\end{array}$ & $\begin{array}{c}\mathrm{H}_{2} / \mathrm{PH}_{3} \\
(190 \\
\mathrm{hrs}) \\
\end{array}$ & $\begin{array}{c}\mathrm{H}_{2} / \mathrm{PH}_{3} \\
(240 \mathrm{hrs})\end{array}$ & $\mathrm{H}_{2}$ & $\begin{array}{c}\mathrm{H}_{2} / 3 \\
\text { vol. } \% \\
\mathrm{H}_{2} \mathrm{O} \\
\end{array}$ & $\begin{array}{c}\mathrm{H}_{2} / 10 \\
\mathrm{ppm} \\
\mathrm{PH}_{3} \\
\end{array}$ & 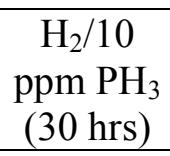 & $\begin{array}{c}\mathrm{H}_{2} / 10 \\
\mathrm{ppm} \mathrm{PH}_{3} \\
(50 \mathrm{hrs})\end{array}$ & $\begin{array}{c}\mathrm{H}_{2} / 10 \\
\mathrm{ppm} \mathrm{PH}_{3} \\
(50 \mathrm{hrs})\end{array}$ \\
\hline $\mathrm{L}(\mathrm{H})$ & $\begin{array}{l}9.47 \\
\text { E-07 }\end{array}$ & $\begin{array}{l}9.17 \\
\text { E-07 }\end{array}$ & $\begin{array}{l}7.37 \\
\text { E-07 }\end{array}$ & $\begin{array}{l}7.49 \\
\text { E-07 }\end{array}$ & $\begin{array}{l}7.34 \\
\text { E-07 }\end{array}$ & $\begin{array}{l}5.60 \\
\text { E-07 }\end{array}$ & $\begin{array}{l}5.44 \\
\text { E-07 }\end{array}$ & $\begin{array}{l}5.58 \\
\text { E-07 }\end{array}$ & $\begin{array}{l}5.59 \\
\text { E-07 }\end{array}$ & $\begin{array}{l}5.65 \\
\text { E-07 }\end{array}$ & $\begin{array}{l}5.54 \\
\text { E-07 }\end{array}$ \\
\hline $\begin{array}{c}\mathrm{R}_{\Omega} \\
\left(\Omega \mathrm{cm}^{2}\right)\end{array}$ & 0.25 & 0.23 & 0.30 & 0.34 & 0.39 & 0.207 & 0.207 & 0.218 & 0.227 & 0.230 & 0.45 \\
\hline $\begin{array}{c}\mathrm{C} \\
\left(\mathrm{F} \mathrm{cm}^{-2}\right)\end{array}$ & $\begin{array}{l}3.04 \\
\text { E-06 }\end{array}$ & $\begin{array}{l}1.64 \\
\text { E-04 }\end{array}$ & $\begin{array}{l}1.04 \\
\text { E-03 }\end{array}$ & $\begin{array}{l}3.23 \\
\text { E-04 }\end{array}$ & $\begin{array}{l}3.56 \\
\text { E-04 }\end{array}$ & $\begin{array}{l}6.30 \\
\text { E-11 }\end{array}$ & $\begin{array}{l}1.32 \\
\text { E-10 }\end{array}$ & $\begin{array}{l}1.86 \\
\text { E-10 }\end{array}$ & $\begin{array}{l}7.58 \\
\text { E-04 }\end{array}$ & $\begin{array}{l}6.30 \\
\text { E-04 }\end{array}$ & $\begin{array}{l}1.34 \\
\text { E-04 }\end{array}$ \\
\hline $\begin{array}{c}\mathrm{R}_{\mathrm{L}} \\
\left(\Omega \mathrm{cm}^{2}\right)\end{array}$ & 0.097 & 0.087 & 0.120 & 0.219 & 0.288 & 0.156 & 0.169 & 0.149 & 0.176 & 0.171 & 0.427 \\
\hline $\begin{array}{l}\mathrm{CPE}_{\mathrm{L}}-\mathrm{Y} \\
\left(\mathrm{S}^{*} \mathrm{~S}^{\wedge} \mathrm{n}\right)\end{array}$ & 1.619 & 1.675 & 2.39 & 2.55 & 0.3387 & 2.71 & 1.269 & 1.56 & 1.94 & 2.18 & 0.15 \\
\hline $\mathrm{CPE}_{\mathrm{L}}-\mathrm{n}$ & 0.57 & 0.70 & 0.66 & 0.44 & 0.354 & 0.444 & 0.547 & 0.594 & 0.442 & 0.411 & 0.361 \\
\hline $\begin{array}{c}\mathrm{R}_{\mathrm{H}} \\
\left(\Omega \mathrm{cm}^{2}\right)\end{array}$ & 0.045 & 0.056 & 0.066 & 0.122 & 0.192 & 0.050 & 0.054 & 0.064 & 0.058 & 0.058 & 0.263 \\
\hline $\begin{array}{c}\mathrm{CPE}_{\mathrm{H}^{-}} \mathrm{Y} \\
\left(\mathrm{S}^{*}{ }_{\mathrm{S}}{ }^{\mathrm{n}}\right)\end{array}$ & 5.028 & 0.9693 & 0.856 & 0.687 & 0.349 & 0.7 & 0.03 & 0.03 & 0.029 & $1.67 \mathrm{E}-03$ & 0.15 \\
\hline $\mathrm{CPE}_{\mathrm{H}}-\mathrm{n}$ & 0.82 & 0.371 & 0.419 & 0.269 & 0.905 & 0.559 & 0.801 & 0.800 & 0.194 & 0.288 & 0.896 \\
\hline
\end{tabular}




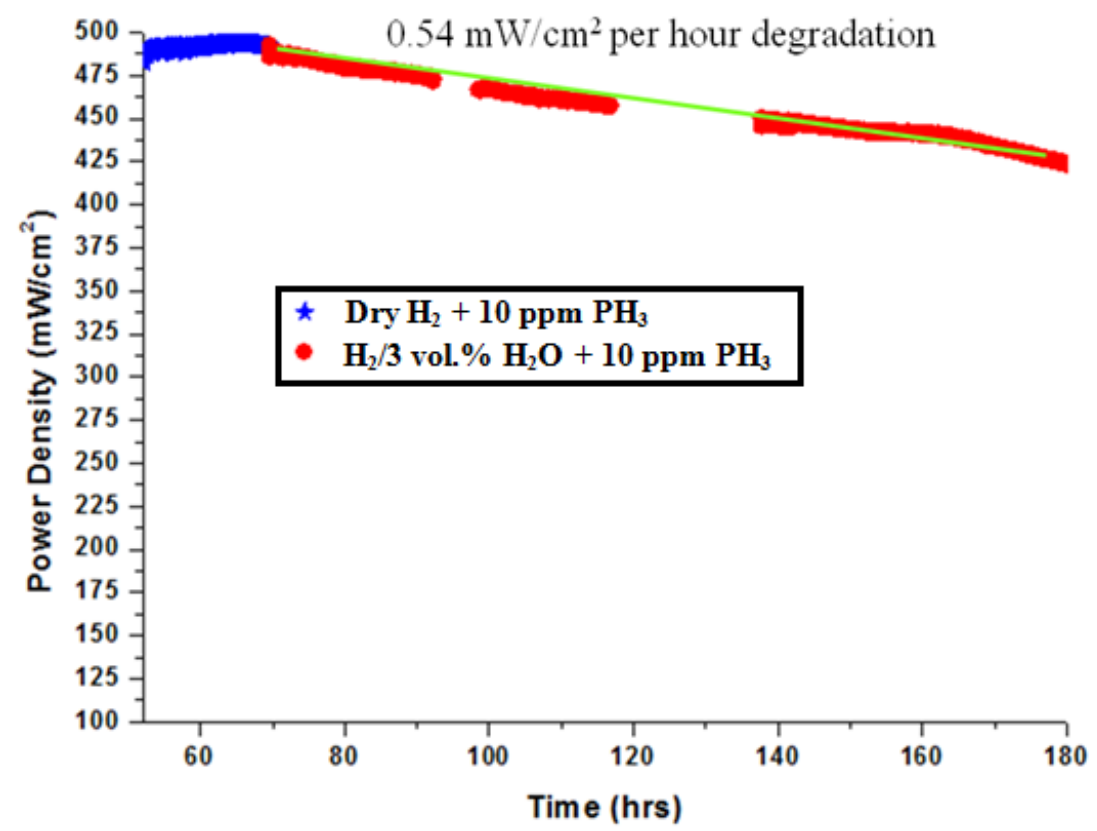

Figure 4. 10 Variation of SOFC Power Density under different testing conditions at $\mathrm{i}=0.6 \mathrm{~A} / \mathrm{cm}^{2}$

Similar to the results shown in Figure 4.3, it can be seen from the Figure 4.10 that the cell performance degrades immediately once the steam is fed into fuel gas. The cell performance degraded at a faster rate $\left(0.54 \mathrm{~mW} / \mathrm{cm}^{2}\right.$ per hour $)$ as compared to 0.43 $\mathrm{mW} / \mathrm{cm}^{2}$ per hour in dry hydrogen with same $\mathrm{PH}_{3}$ level. The corresponding EIS and IV curves measurements were also carried out, which is plotted in Figure 4.11 and 4.12, respectively. From EIS analysis, it was found that the polarization resistance of the button cell had $183 \%$ increases after 150 hrs successive gas exposure, while the ohmic resistance increased 119\%. From Table 4.1, compared with the lower ohmic resistance increases in dry hydrogen, it was indicated that the conductivity became worse in wet hydrogen, which might be due to the significant secondary phase formation under exposure of $\mathrm{PH}_{3}$ and steam. The higher steam content led to faster failure of the cell. The poisoning effect of $\mathrm{PH}_{3}$ was strongly associated with the content of steam in the fuel gas. The microstructural evolution of the Ni-YSZ working electrodes after $\mathrm{PH}_{3}$ exposure was carried out to elucidate the reason for the change in both charge transfer resistance and diffusion resistance, which will be illustrated in the next section. 


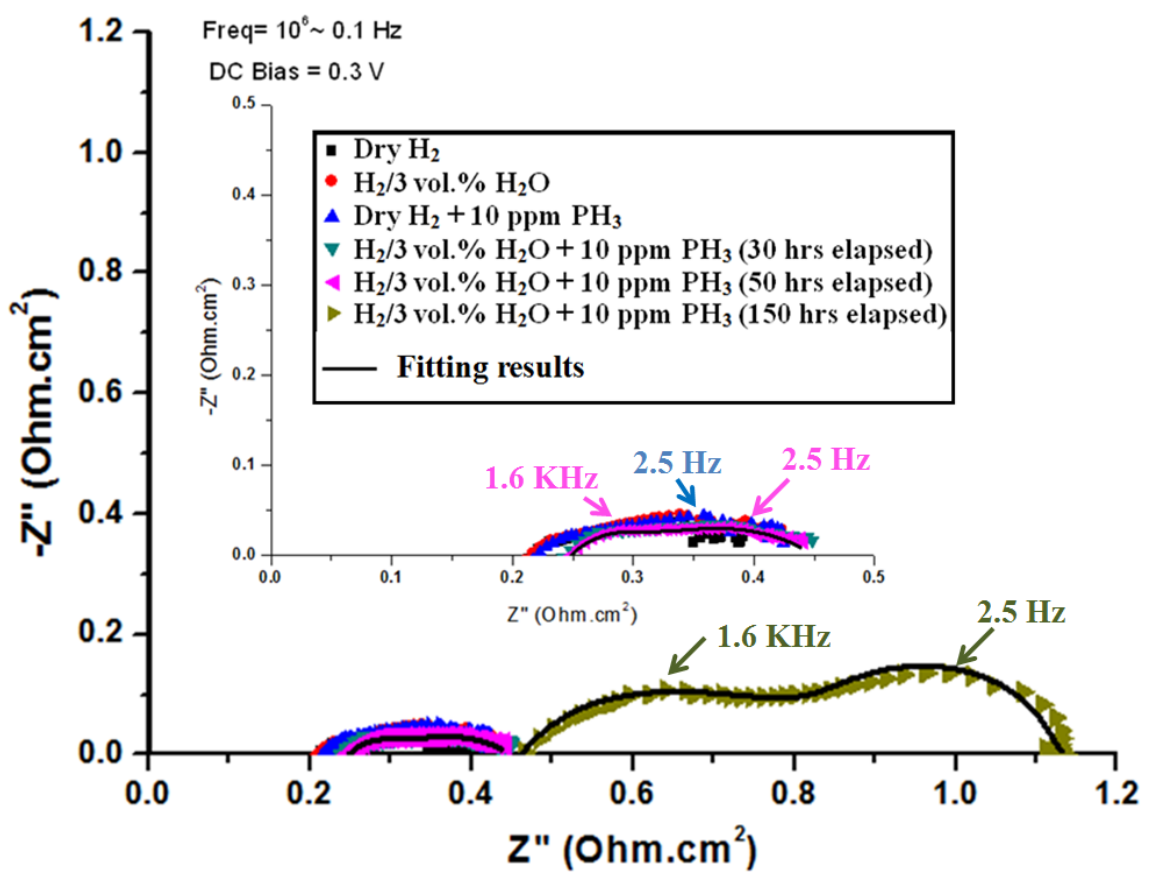

Figure 4. 11 Corresponding Impedance plots for SOFC operating at $0.3 \mathrm{~V}$ potential bias

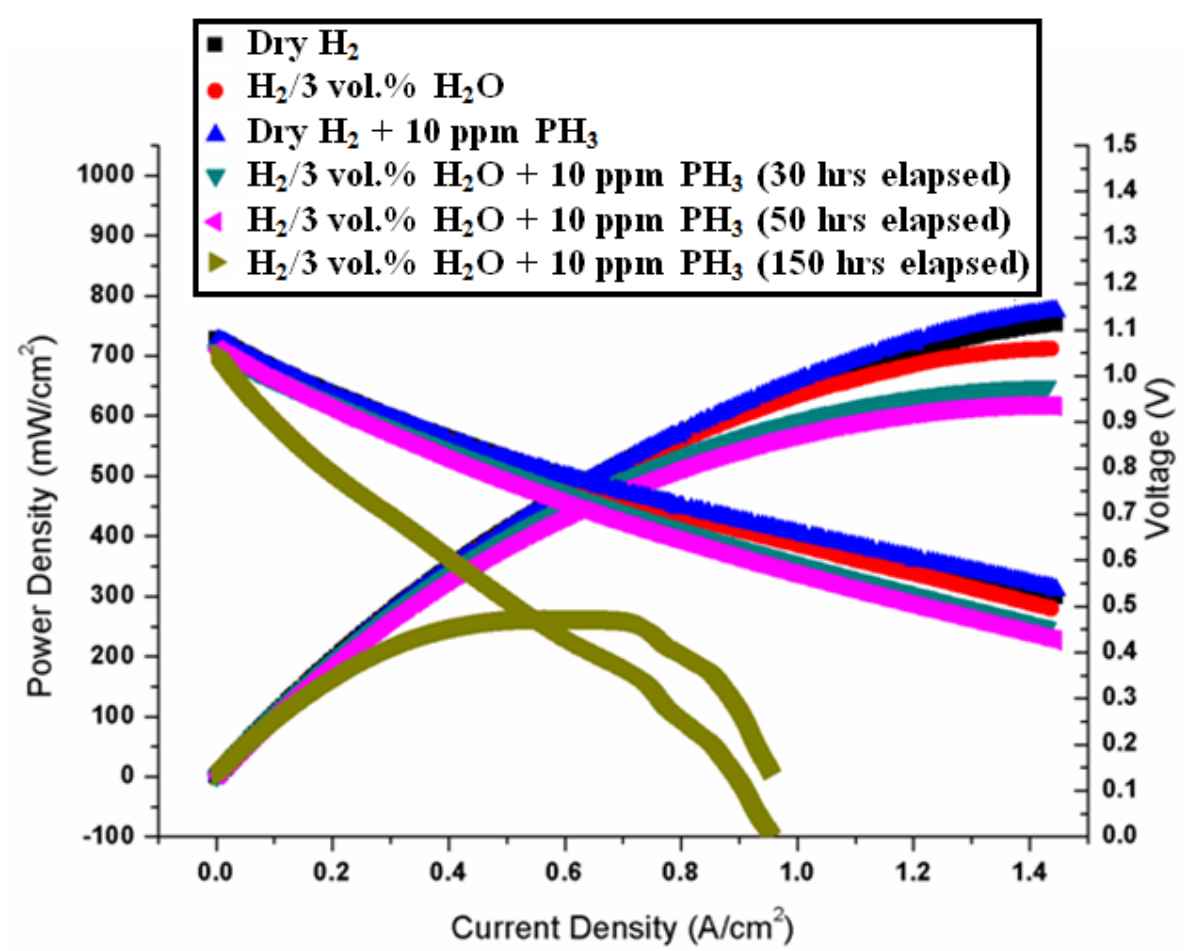

Figure 4. 12 Corresponding I-V curves of SOFC operating at $800{ }^{\circ} \mathrm{C}$ 


\subsubsection{Surface IR Temperature Measurements}

As described in Chapter 3, cell performance plays an important role in the surface temperature variations. Based on the surface temperature measurements, the polarization effects on cell electrode reaction can be investigated, which is used to complement the common electrochemical measurements (i.e. EIS, Voltammetry) for validation and development of SOFC numerical models, including both electrochemical and structural simulations. In the present work, the surface IR temperature was monitored and recorded over time during the $\mathrm{PH}_{3}$ exposure testing mentioned previously.

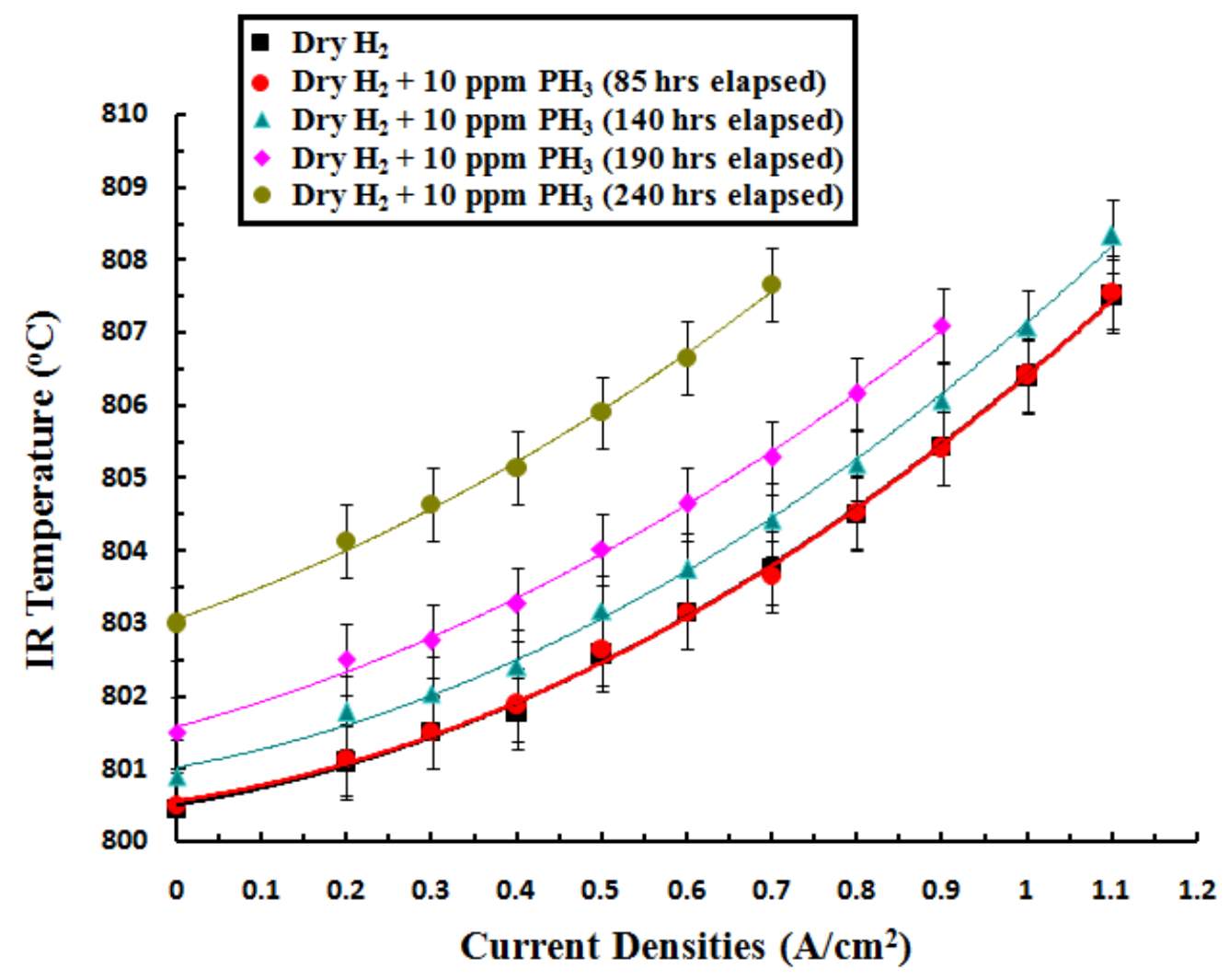

Figure 4. 13 Surface temperature comparisons in dry Hydrogen containing $\mathrm{PH}_{3}$ 
It has been shown that the final steady state surface IR temperature is independent of the intermediate current steps and only depends on the final loading current density. The changes of steady-state button cell surface temperature were plotted against loading current densities and the comparison as the exposure time elapsed was illustrated in Figure 4.13 and 4.14. As shown, similar trends of button cell surface temperature variation were obtained during the $\mathrm{PH}_{3}$ exposure, not matter in dry hydrogen or in hydrogen with steam. As the cell performance degraded over time, surface IR temperature increased and the rate of IR temperature variation as the function of current densities also increased. The relation between surface temperature and current density is found to be nonlinear.

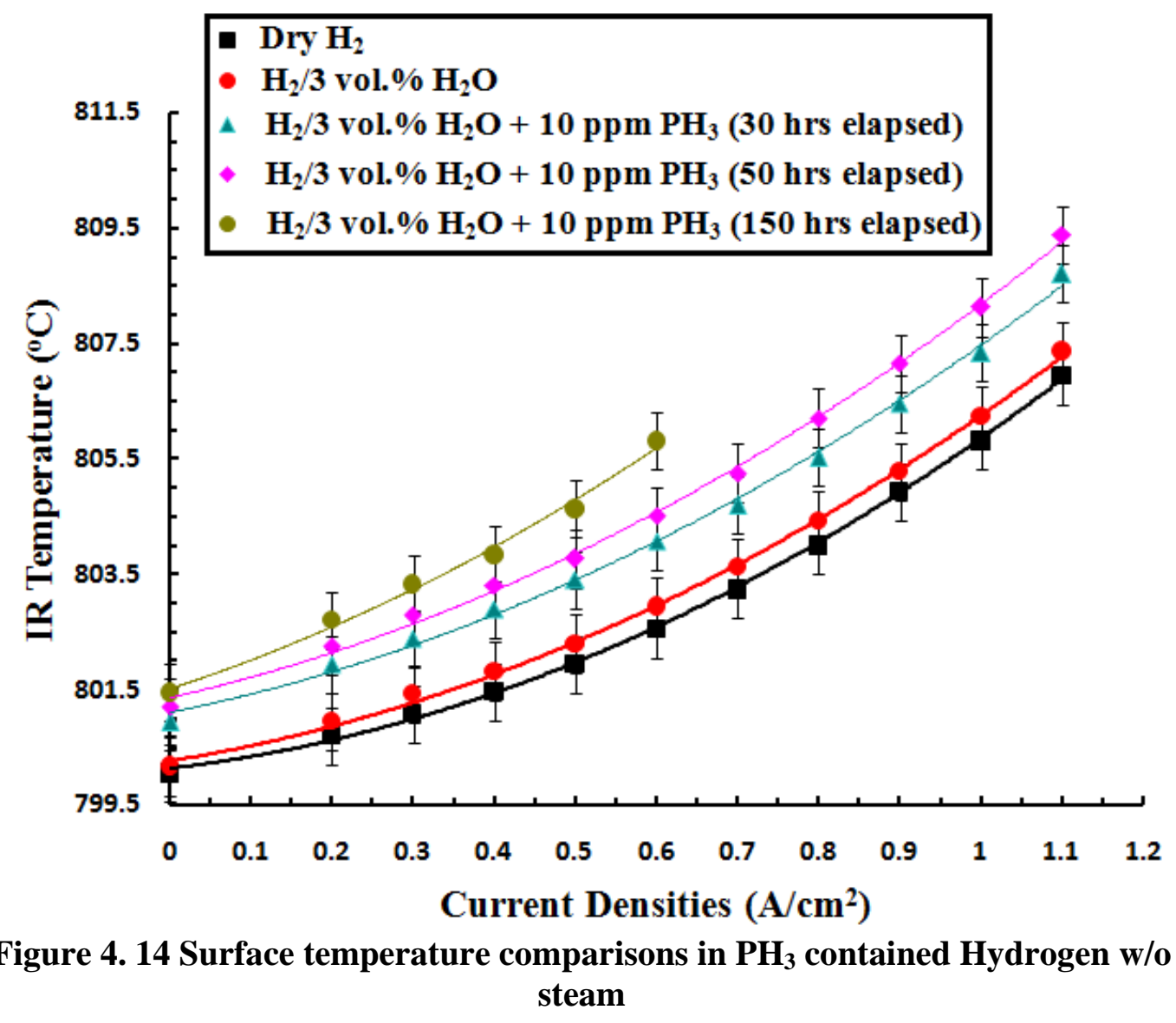


Analogous to the performance degradation history shown in Figures 4.6, surface IR temperature variations plotted in Figure 4.13 demonstrates that surface temperature remained stable until the cell performance started degradation under exposure of $10 \mathrm{ppm}$ $\mathrm{PH}_{3}$ with dry $\mathrm{H}_{2}$. As the cell degraded over time, the surface temperature increased with the polarization following the corresponding two steps: slowly initially and then sharply increased due to the cell failure. On the other hand, the button cell exposed to in $\mathrm{H}_{2} / 3$ vol. $\% \mathrm{H}_{2} \mathrm{O}$ with same $10 \mathrm{ppm} \mathrm{PH}_{3}$ showed higher surface temperature under the same current densities, as shown in Figure 4.14.

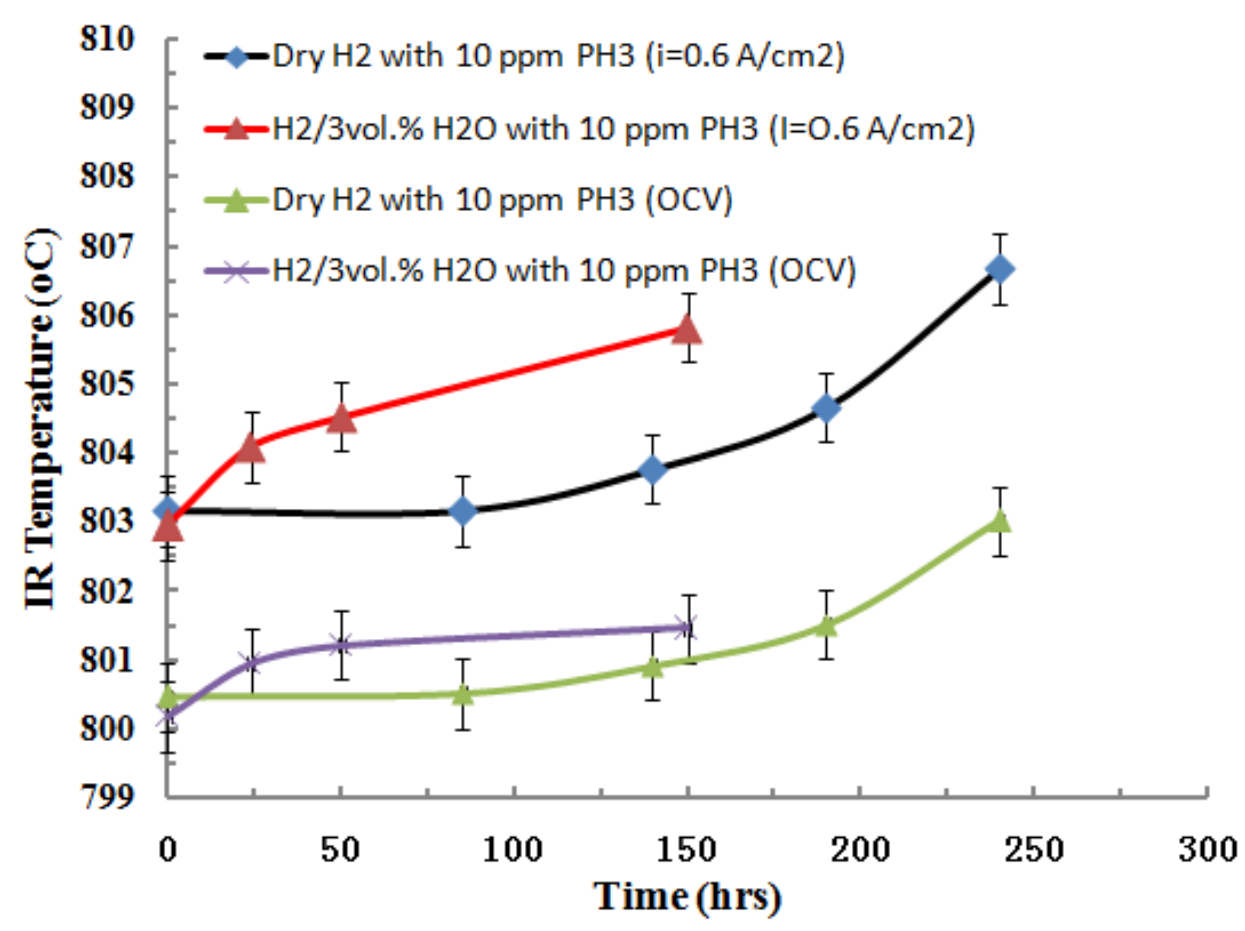

Figure 4. 15 Surface IR Temperature Variation under different testing conditions

As illustrated in Figure 2.13, Au (polished) has a low and constant emissivity of 0.03 . Therefore, the polished gold strip on the cell surface has little contribution to the surface temperature variation during the operation. Surface IR Temperature variations could be attributed to two factors: electrochemical performance of fuel cell and IR 
emissivity of electrode materials. Coupled with the previous studies, two sets of experiments were compared to help understanding these two factors.

The first set was designed and carried out in clean hydrogen w/o steam and clean coal syngas, as shown in Figure 3.18 and 3.19. Without deleterious contaminants, there is no secondary phase formation in such clean environments, and the IR emissivity change of electrode materials is negligible during the short term tests. As explained in the previous chapter, these tests indicated that the dominant source of the surface temperature variation is entropic heating from fuel oxidation and the minor source is ohmic heating, while the contribution of the water gas shift reaction is negligible $[113,114]$.

In the second set, which is shown in Figure 4.13 and 4.14 , the surface IR temperature variations were investigated over time due to the poisoning effects of $\mathrm{PH}_{3}$ under different environments. As the $\mathrm{PH}_{3}$ exposure time elapsed, the surface IR temperature variations were plotted in Figure 4.15 under open circuit voltage (OCV) and operating conditions respectively. Because of the different tests, the fuel cell performances showed a little difference, but the trend of temperature change was determined.

During the $\mathrm{PH}_{3}$ exposure, Ni-YSZ reacted with $\mathrm{PH}_{3}$ and generated the P-based secondary phase, which would cause the fuel cell performance degradation and IR emissivity of electrode change. The effect of electrode IR emissivity change was indentified from the change of surface IR emission under OCV conditions. There was no loading current or potential bias under OCV, and thus the electrode surface IR emission variation was just only attributed to the change of electrode material emissivity, even though the cell operating temperature might be not changed. The trend of IR emission change under OCV was consistent with the process of P-based secondary phase formation. In Figure 4.15, the purple line showed the results obtained in $\mathrm{H}_{2} / 3$ vol.\% $\mathrm{H}_{2} \mathrm{O}$ with $10 \mathrm{ppm} \mathrm{PH}_{3}$. The electrode surface IR emission initially increased due to the 
initiation of secondary phase formation and material IR emissivity change. The change of IR emission later became slower and slower and then reached a stable status since the electrode surface was covered by the secondary phase. The comparison under dry $\mathrm{H}_{2}$ and $\mathrm{H}_{2} / 3$ vol. $\% \mathrm{H}_{2} \mathrm{O}$ with $10 \mathrm{ppm} \mathrm{PH}_{3}$ also demonstrated that it took a longer time to have a stable surface IR emission in dry $\mathrm{H}_{2}$, because the Ni-YSZ was less susceptible to $\mathrm{PH}_{3}$ contaminant in dry conditions and the secondary phase formation was not so significant as that in wet conditions. As shown in the green line in Figure 4.15, the surface IR emission kept increasing before the cell failed, while the electrode surface was not fully covered in dry hydrogen with $\mathrm{PH}_{3}$. The secondary phase formation and microstructure reconstructions were confirmed via the post-term characterization, such as SEM, XPS and XRD analysis, which will be discussed in the next section.

On the other hand, under fuel cell operating conditions, the reaction between $\mathrm{PH}_{3}$ and Ni-YSZ and thus the formation of secondary phase were more significant. As shown, the higher change of surface IR emission was obtained due to the combined effect of cell performance degradation and material emissivity variations. Besides secondary phase formation monitoring, these tests were carried out to provide researchers and industry with the data for the SOFC thermal and electrochemical modeling and then clarifying the degradation behavior and fundamental degradation mechanism.

\subsubsection{Microstructural Analysis}

The fuel cell performance has been subjected to the secondary phase formation due to the reaction between $\mathrm{PH}_{3}$ and Ni-YSZ. In order to elucidate the degradation mechanism, the micro-structural evolution of the Ni-YSZ anode after exposure to $\mathrm{PH}_{3}$ containing fuel gas was analyzed.

Following termination of electrochemical tests as described in Figure 4.6 and 4.9, 
the cell surface and cross-section were analyzed using SEM/EDS and XRD. The comparison of XRD patterns under 10ppm $\mathrm{PH}_{3}$ containing $\mathrm{H}_{2}$ w/o 3vol.\% $\mathrm{H}_{2} \mathrm{O}$ conditions is illustrated in Figure 4.16 and the corresponding surface and cross-section SEM micrographs are shown in Figure 4.17 and 4.18.

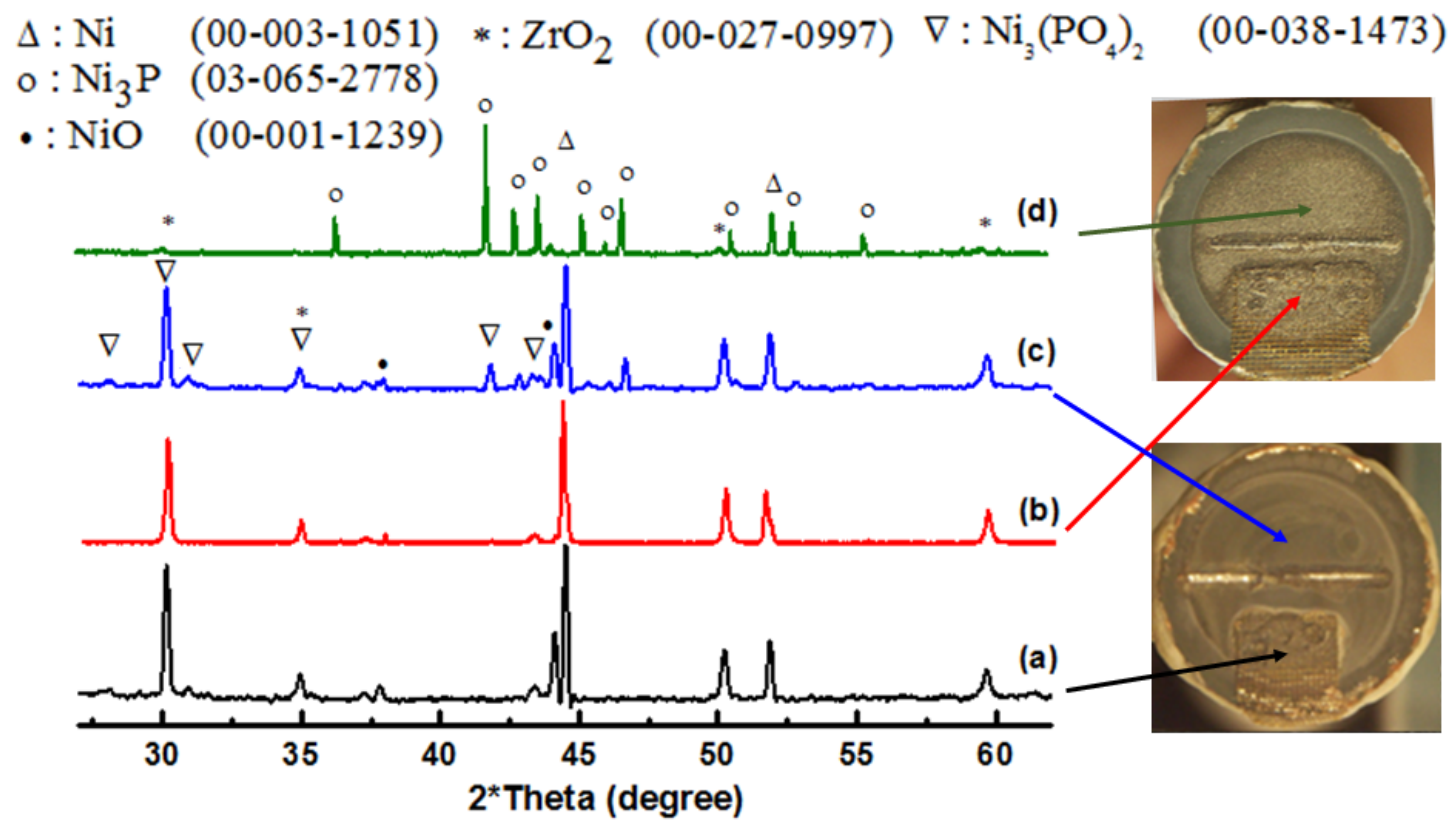

Figure 4. 16 XRD patterns of the Ni-YSZ electrode: (a) the electrode under Au mesh after exposure to $10 \mathrm{ppm} \mathrm{PH}_{3}$ in dry $\mathrm{H}_{2}$ for $300 \mathrm{hrs}$; (b) the electrode under $\mathrm{Au}$ mesh after exposure to $10 \mathrm{ppm} \mathrm{PH}_{3}$ in $\mathrm{H}_{2} / 3$ vol.\% $\mathrm{H}_{2} \mathrm{O}$ for $200 \mathrm{hrs}$; (c) the electrode open surface after exposure to $10 \mathrm{ppm} \mathrm{PH}_{3}$ in dry $\mathrm{H}_{2}$ for $300 \mathrm{hrs}$ and (d) the electrode open surface after exposure to $10 \mathrm{ppm} \mathrm{PH}_{3}$ in $\mathrm{H}_{2} / 3$ vol. \% $\mathrm{H}_{2} \mathrm{O}$ for $200 \mathrm{hrs}$ at $\mathrm{i}=0.6 \mathrm{~A} / \mathrm{cm}^{2}$

As shown in Figure 4.16, the XRD analysis was conducted on two locations under either dry or wet hydrogen conditions. One set of XRD patterns were acquired on the electrode surface under the Au mesh (current collector). The XRD patterns (Figure 4.16(a) and (b)) indicated that the multiple phases of $\mathrm{Ni} / \mathrm{NiO}, \mathrm{YSZ}$ and nickel phosphate such as $\mathrm{Ni}_{3}\left(\mathrm{PO}_{4}\right)_{2}$ at the active Ni/YSZ interface. The other set of analysis was carried out on the 
electrode open surface, which was directly exposed to the injected $\mathrm{PH}_{3}$ containing hydrogen. As shown in Figure 4.16(c), under dry condition YSZ phase can still be found on the open anode surface, whereas no YSZ phase was found on the open anode surface under wet condition (Figure 4.16(d)). The XPS was utilized to further identify the chemical composition of the electrode (open surface and cross section) under wet condition. Figure 4.19 reveals that the peaks associated with $\mathrm{P}, \mathrm{Ni}$ and $\mathrm{O}$ were found in the XPS spectrum of the electrode after $\mathrm{PH}_{3}$ exposure in $\mathrm{H}_{2} / 3 \mathrm{vol} . \% \mathrm{H}_{2} \mathrm{O}$. $\mathrm{The} \mathrm{Zr}_{3 \mathrm{~d}}$ peaks appeared in the cross section of anode, but disappeared completely on the open anode surface. Because of the outward diffusion to the electrode surface of $\mathrm{Ni}$, the YSZ was buried underneath the P based secondary phase. Without the assistance of YSZ under wet and reducing $\left(\mathrm{H}_{2}\right)$ environment, nickel is preferred to react with $\mathrm{PH}_{3}$ to form $\mathrm{Ni}_{3} \mathrm{P}$, instead of nickel phosphate formation at triple phase boundary (TPB) of Ni/YSZ.

The corresponding SEM images (Figure 4.17) show that there was more significant surface corrosion and $\mathrm{Ni}$ agglomeration occurred under wet condition than under dry hydrogen. These facts elucidate the difference of surface IR emissivity variation under two cases, as described in Figure 4.15. The Ni migration and P based secondary phase formation degrades the electrocatalytic activity of $\mathrm{Ni}$ toward oxidation of the fuel gas and inhibits the ability of electrode to transport fuel gas and oxygen ions in the electrode. Therefore, the charge transfer resistance increases with prolonged time during exposure to the $\mathrm{PH}_{3}$ containing fuel gas. The Ni migration and secondary phase stratification could also cause substantial internal stresses in the YSZ matrix, which can lead to the horizontal elongated crack development in the nickel-free YSZ matrix if the stress development cannot be accommodated [9]. The rapid failure shown in performance history, which is illustrated in Figure 4.6, might be resulted from this mechanism, which is consistent with the horizontal elongated crack shown in the SEM images of crosssection (Figure 4.18(b)). 

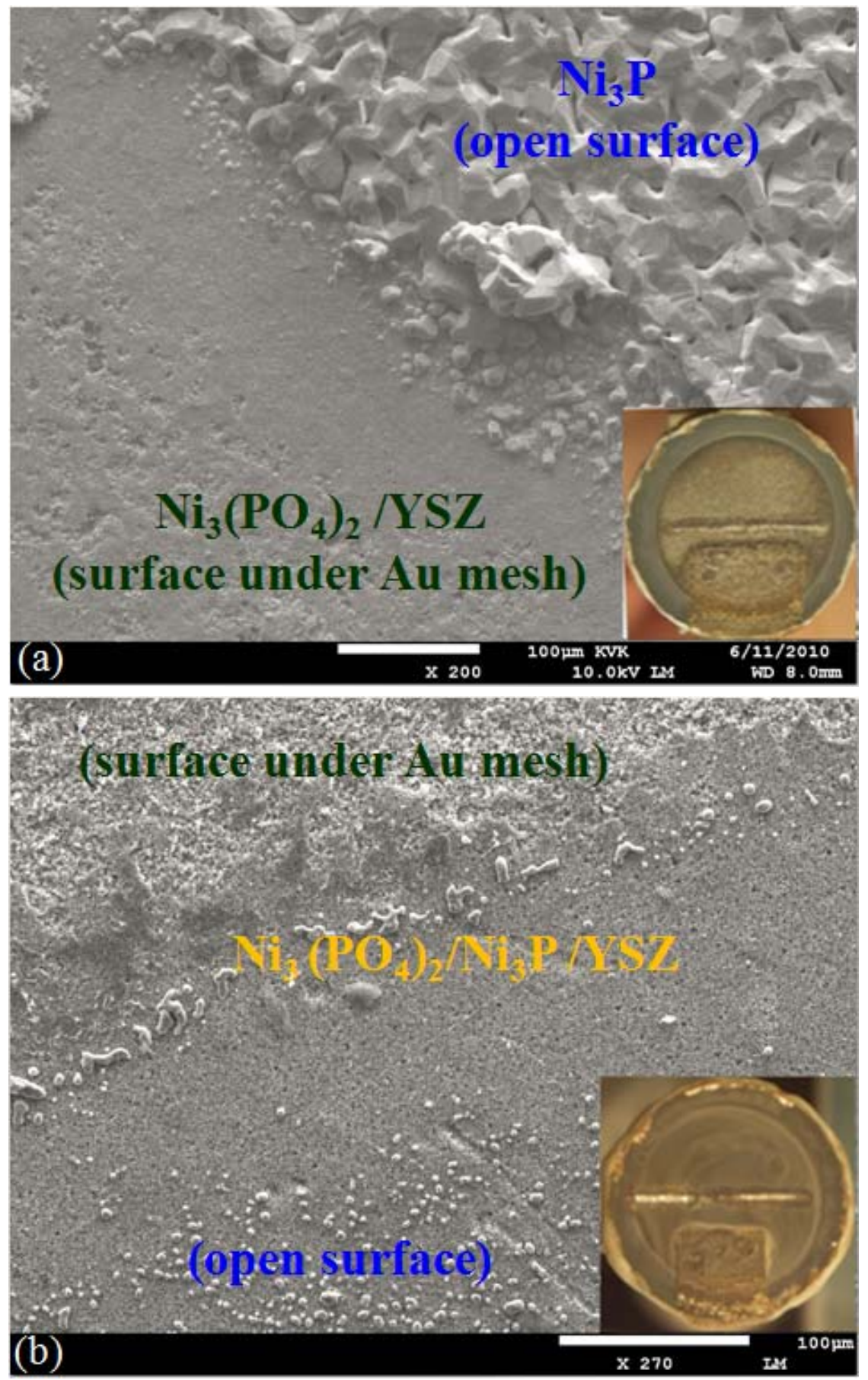

Figure 4. 17 SEM Micrograph of the Ni-YSZ anode surface after exposure to 10 ppm $\mathrm{PH}_{3}$ in (a) $\mathrm{H}_{2} / 3$ vol. \% $\mathrm{H}_{2} \mathrm{O}$ for 200 hrs and (b) dry $\mathrm{H}_{2}$ for 300 hrs at $\mathrm{i}=0.6$ $\mathrm{A} / \mathrm{cm}^{2}$ 

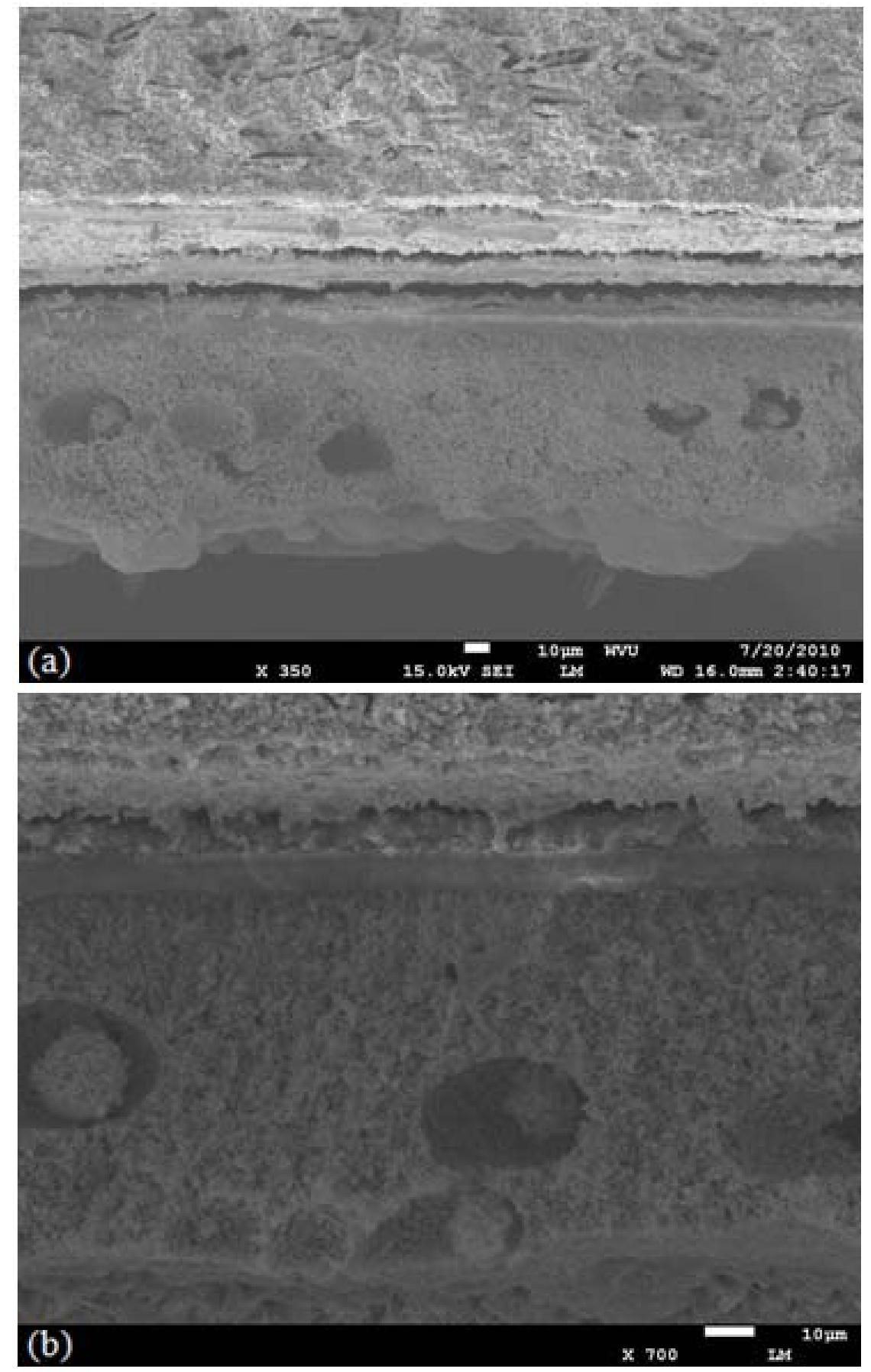

Figure 4. 18 SEM Micrograph of the Ni-YSZ anode cross-section after exposure to $10 \mathrm{ppm} \mathrm{PH}_{3}$ in (a) $\mathrm{H}_{2} / 3$ vol.\% $\mathrm{H}_{2} \mathrm{O}$ for 200 hrs and (b) dry $\mathrm{H}_{2}$ for $300 \mathrm{hrs}$ at $\mathrm{i}=\mathbf{0 . 6}$ $\mathrm{A} / \mathrm{cm}^{2}$ 

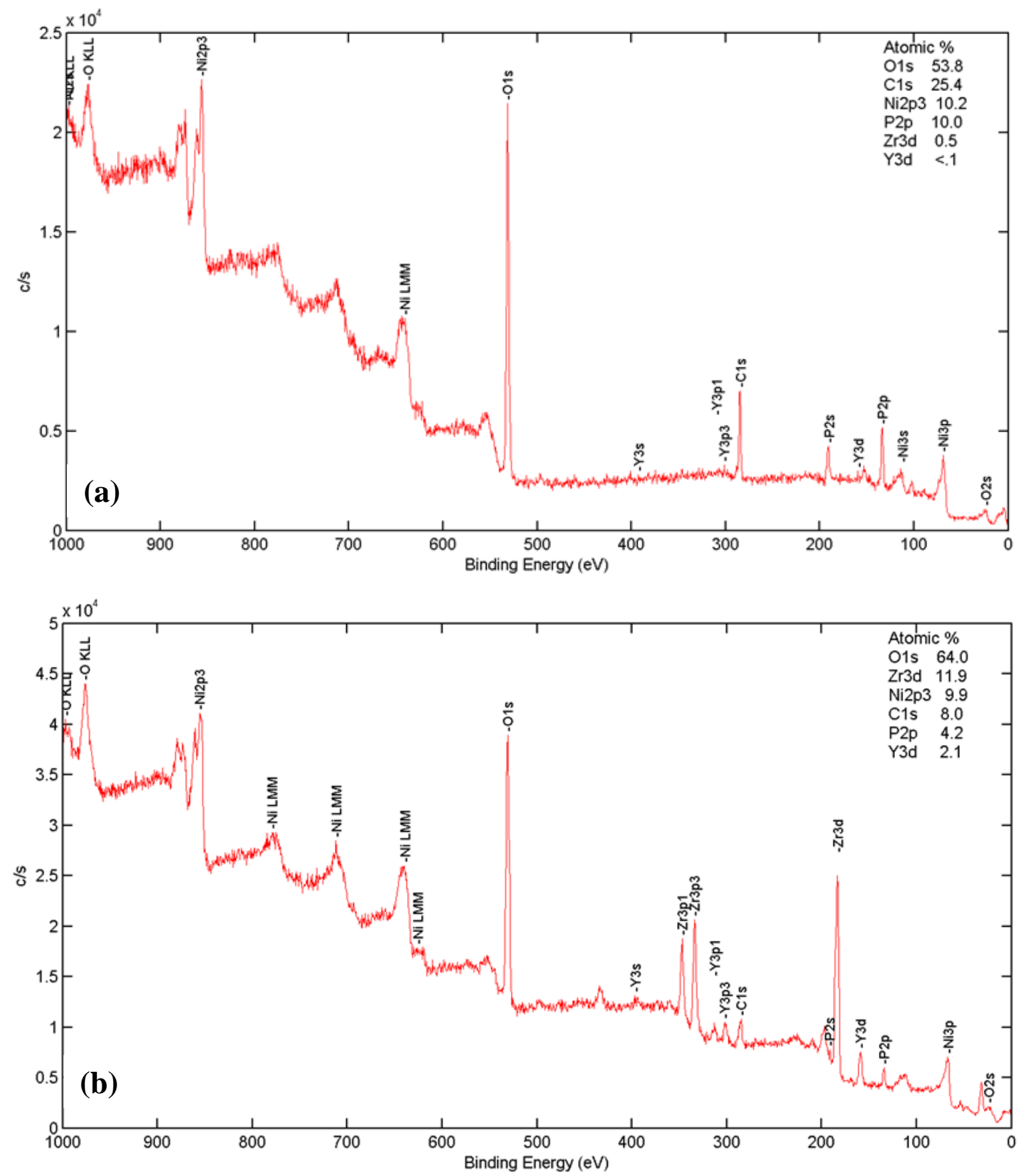

Figure 4. 19 XPS spectra of the Ni-YSZ anode after exposure to $10 \mathrm{ppm} \mathrm{PH}_{3}$ in $\mathrm{H}_{2} / 3$ vol. $\% \mathrm{H}_{2} \mathrm{O}$ for $200 \mathrm{hrs}$ at $\mathrm{i}=0.6 \mathrm{~A} / \mathrm{cm}^{2}$ : (a) open surface and (b) cross section 
The post-term characterizations demonstrated two different types of $\mathrm{P}$ based secondary phases resulting from the incorporation of $\mathrm{P}$ and steam into the electrode. To account for the formation of P-based secondary phases, the following reaction may be considered under different testing conditions:

$$
\begin{aligned}
& \mathrm{yPH}_{3}(g)+x N i(s) \rightarrow N i_{x} \mathrm{P}_{\mathrm{y}}(\mathrm{s})+\frac{3}{2} \mathrm{yH}_{2}(\mathrm{~g}) \\
& \mathrm{PH}_{3}(g)+x \mathrm{H}_{2} \mathrm{O}(\mathrm{g}) \rightarrow \mathrm{HPO}_{x}(\mathrm{~g})+(\mathrm{x}+1) \mathrm{H}_{2}(\mathrm{~g}) \\
& 2 \mathrm{HPO}_{x}(\mathrm{~g})+y N i(\mathrm{~s}) \rightarrow \mathrm{Ni}_{\mathrm{y}}\left(\mathrm{PO}_{\mathrm{x}}\right)_{2}(\mathrm{~s})+\mathrm{H}_{2}(\mathrm{~g})
\end{aligned}
$$

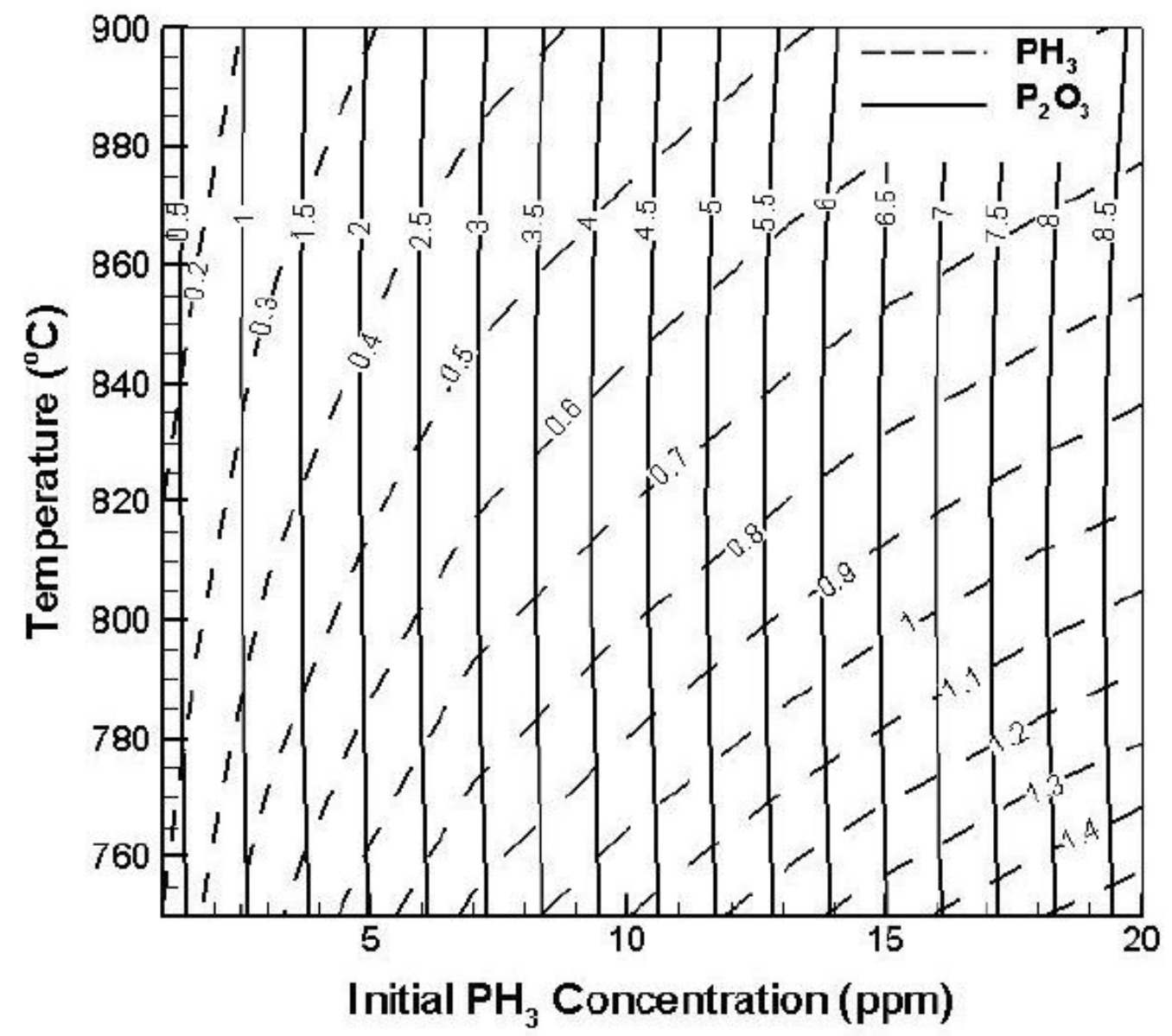

Figure 4. 20 Phase diagram for the equilibrium concentrations of $\mathrm{PH}_{3}$ and $\mathrm{P}_{2} \mathrm{O}_{3}$ as a function of the initial $\mathrm{PH}_{3}$ concentration [Ref 31] 
$\Delta: \mathrm{Ni}(00-003-1051) \cdot: \mathrm{NiO}(00-001-1239) *: \mathrm{ZrO}_{2}(00-027-0997)$

$\nabla: \mathrm{Ni}_{3}\left(\mathrm{PO}_{4}\right)_{2} \quad(00-038-1473) \quad \mathrm{Ni}_{3} \mathrm{P}(03-065-2778)$

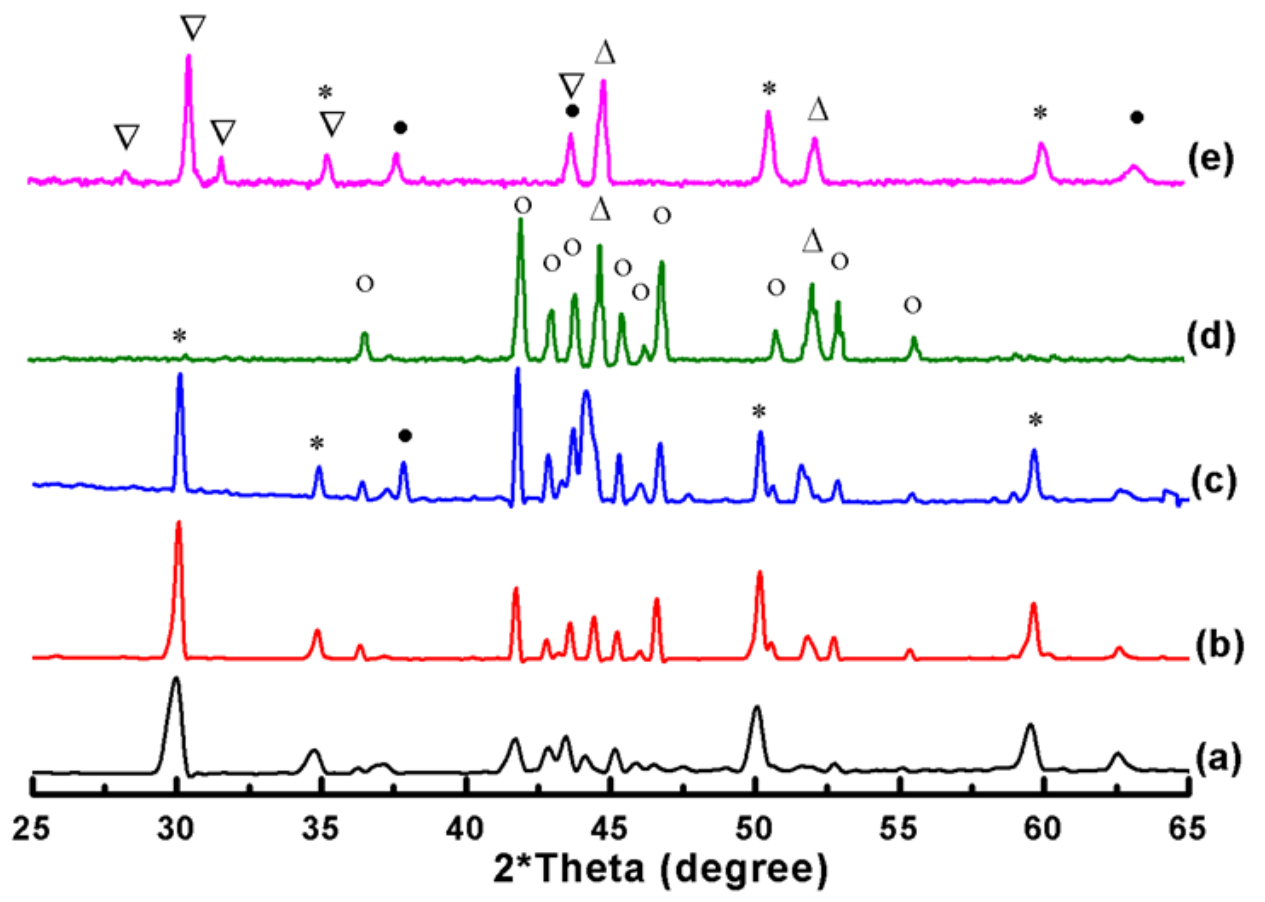

Figure 4. $21 \mathrm{XRD}$ patterns of the Ni-YSZ electrode: (a) exposure to $20 \mathrm{ppm} \mathrm{PH}_{3}$ in dry $\mathrm{H}_{2}$ for $100 \mathrm{hrs}$ at $\mathrm{OCV}$; (b) exposure to $20 \mathrm{ppm} \mathrm{PH}_{3}$ in $\mathrm{H}_{2} / 26$ vol.\% $\mathrm{H}_{2} \mathrm{O}$ for 100 hrs at OCV; (c) exposure to $20 \mathrm{ppm} \mathrm{PH}_{3}$ in dry $\mathrm{H}_{2}$ for $100 \mathrm{hrs}$ at $0.3 \mathrm{~V}$ of potential bias; (d) Au mesh with Ni paste on electrode surface after exposure to $10 \mathrm{ppm} \mathbf{P H}_{3}$ in $\mathrm{H}_{2}$ with 3-6 vol.\% $\mathrm{H}_{2} \mathrm{O}$ for $100 \mathrm{hrs}$ at $0.3 \mathrm{~V}$ of potential bias and (e) the electrode

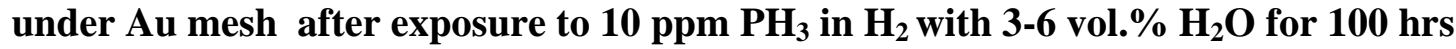
at $0.3 \mathrm{~V}$ of potential bias

According to the thermodynamic calculations illustrated in Figure 4.20 [31], the major stable form of $\mathrm{P}$ under the experimental conditions is $\mathrm{P}_{2} \mathrm{O}_{3}$ in the range of 750 $900{ }^{\circ} \mathrm{C}$, which indicated that most of $\mathrm{PH} 3$ is oxidized due to the presence of water vapor in the fuel gas. It is also reported that $\mathrm{PH}_{3}$ can be converted to phosphoric acid, or $\mathrm{HPO}_{x}$ (g), in the presence of steam between $700^{\circ} \mathrm{C}$ and $900{ }^{\circ} \mathrm{C}$, which can attack the nickel electrode and YSZ electrolyte and has a deleterious effect on the SOFC performance [11, 12]. Due to the lack of the in-situ gas composition measurements, the real form and 
concentration of $\mathrm{PH}_{3}$ are still not clear. To further investigate their formation and degradation mechanisms, short-term $\mathrm{PH}_{3}$ exposure tests were repeated under dry and wet hydrogen conditions w/o loading potential bias, respectively. The short-term experimental results illustrate that no cell performance degradation occurs during exposure to $\mathrm{PH}_{3}$ with dry $\mathrm{H}_{2}$, but the fuel cell performance degrades significantly as the moisture content in the fuel gas increases.

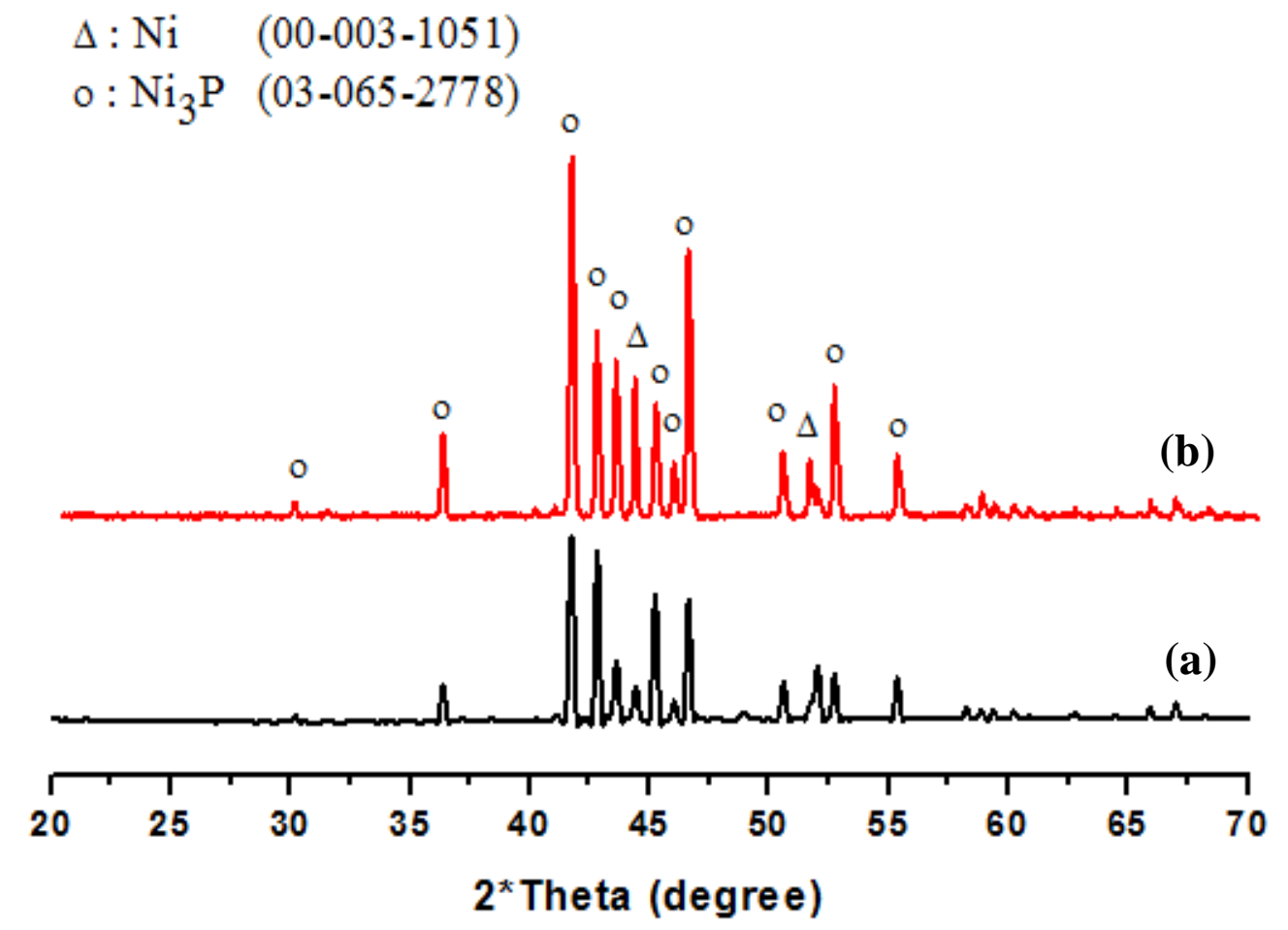

Figure 4. $22 \mathrm{XRD}$ patterns of the Ni plate exposure to $20 \mathrm{ppm} \mathrm{PH}_{3}$ for $100 \mathrm{hrs}$ at OCV: (a) in dry $\mathrm{H}_{2}$ and (b) in $\mathrm{H}_{2} / 26$ vol.\% $\mathrm{H}_{2} \mathrm{O}$

Figure 4.21 reveals the XRD patterns obtained from the Ni-YSZ electrode tested under different conditions. $\mathrm{Ni}_{3} \mathrm{P}$ was the major phases observed on the electrode after exposure to ppm level of $\mathrm{PH}_{3}$ under either dry or wet hydrogen condition at open circuit voltage condition (OCV), as shown in Figure 4.21 (a) and (b). From the corresponding SEM micrographs (Figure 4.23 (a) and (b)), it is found that the surface corrosion and $\mathrm{Ni}$ 
agglomeration are more significant under wet hydrogen than under dry condition images. But, the YSZ phase still can be found on the anode surface since the Ni migration and $\mathrm{Ni}_{3} \mathrm{P}$ formation were not so significant to bury the YSZ phase during the short term exposure.

Under the fuel cell operating condition (e.g. $0.3 \mathrm{~V}$ bias), $\mathrm{PH}_{3}$ is converted to phosphoric acid, or $\mathrm{HPO}_{\mathrm{x}}(\mathrm{g})$, in the presence of steam. The potential bias across a fuel cell might accelerate the phosphoric acid absorption on TPB and reaction with Ni/YSZ electrode. Figure 4.21 (e) indicates that the dominant P-based secondary phase was found to be nickel phosphate such as $\mathrm{Ni}_{3}\left(\mathrm{PO}_{4}\right)_{2}$, at the active Ni-YSZ interface, which can be explained by equations (4.3) and (4.4). On the surface of Au mesh (current collector) with $\mathrm{Ni}$ paste, $\mathrm{Ni}_{3} \mathrm{P}$ is formed instead on the surface of $\mathrm{Au}$ mesh (current collector) with Ni paste without assistance of YSZ, as demonstrated in Figure 4.21 (d). Similarly, the reaction between Ni plate and $\mathrm{PH}_{3}$ (Figure 4.22), the formation of nickel phosphide phase $\left(\mathrm{Ni}_{3} \mathrm{P}\right)$ could be due to the reaction of $\mathrm{PH}_{3}$ and $\mathrm{Ni}$ (equation (4.2)), or be produced from the nickel phosphate precursor which is then reduced in hydrogen [119-121].

Figure 4.21 (c) shows the XRD pattern obtained under the fuel cell operation and dry fuel gas conditions. Nickel phosphide $\left(\mathrm{Ni}_{3} \mathrm{P}\right)$ is formed rather than nickel phosphate, while the small amount of nickel phosphate phase could be resulted from the water generated through the electrode reaction. In contrary to performance degradation in $\mathrm{PH}_{3}$ with wet $\mathrm{H}_{2}$ (Figure 4.3), there is no fuel cell performance degradation during short term exposure to $\mathrm{PH}_{3}$ with dry $\mathrm{H}_{2}$, which indicates that nickel phosphate has more drastic effect on Ni/YSZ electrodes rather than nickel phosphide. The more content of $\mathrm{PH}_{3}$ and steam, the more significant nickel phosphate formation is, and the faster fuel cell degrades. 


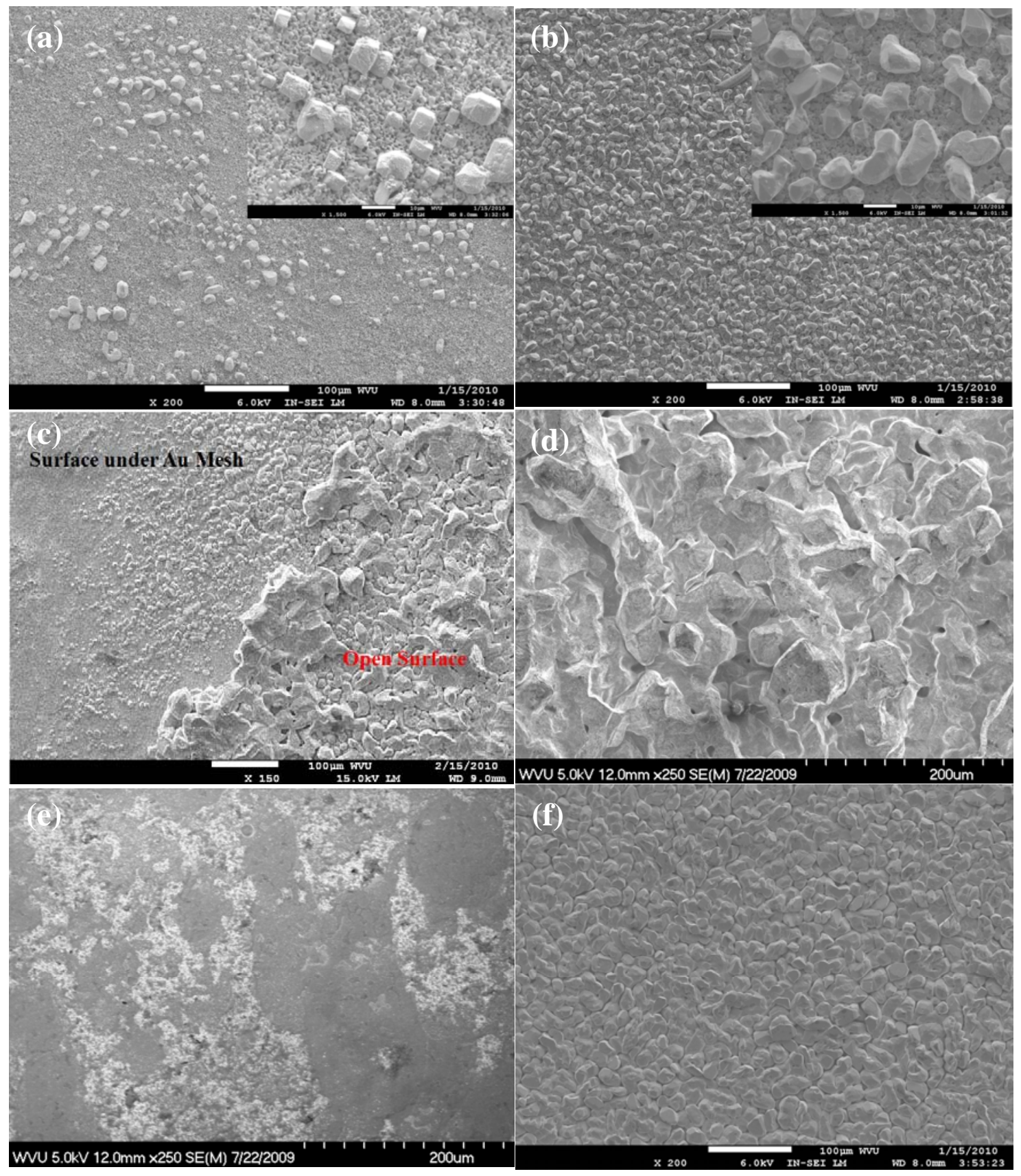

Figure 4. 23 SEM Micrographs: (a) Ni-YSZ electrode exposure to $20 \mathrm{ppm} \mathrm{PH}_{3}$ in dry $\mathrm{H}_{2}$ for 100 hrs at OCV; (b) Ni-YSZ electrode exposure to 20 ppm $\mathrm{PH}_{3}$ in $\mathrm{H}_{2} / 26$ vol.\% $\mathrm{H}_{2} \mathrm{O}$ for 100 hrs at OCV; (c) Ni-YSZ electrode exposure to 20 ppm $\mathrm{PH}_{3}$ in dry $\mathrm{H}_{2}$ for 100 hrs at $0.3 \mathrm{~V}$ of potential

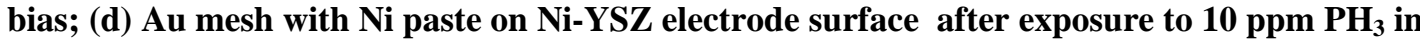
$\mathrm{H}_{2}$ with 3-6 vol. \% $\mathrm{H}_{2} \mathrm{O}$ for $100 \mathrm{hrs}$ at $0.3 \mathrm{~V}$ of potential bias, (e) the electrode under Au mesh after exposure to 10 ppm $\mathrm{PH}_{3}$ in $\mathrm{H}_{2}$ with 3-6 vol.\% $\mathrm{H}_{2} \mathrm{O}$ for 100 hrs at $0.3 \mathrm{~V}$ of potential bias and (f) Ni plate exposure to 20 ppm $\mathrm{PH}_{3}$ in $\mathrm{H}_{2} / 26$ vol. \% $\mathrm{H}_{2} \mathrm{O}$ for $100 \mathrm{hrs}$ at $\mathrm{OCV}$ 
It is notable that the formation of nickel phosphate is strongly related to the potential bias and active Ni-YSZ interface as well as the concentration of $\mathrm{PH}_{3}$ and steam. During the long-term operation of SOFC, the Ni migration and agglomeration on the electrode surface is notable, which will bury the YSZ phase and block the fuel gas and oxygen ions transportation in the electrode. Therefore, the fuel cell performance degradation takes place even with dry fuel gas conditions during long-term operation. On the other hand, once the YSZ phase is buried, nickel phosphide formation is preferred to form instead of nickel phosphate, which is similar to the reaction between Ni paste (or Ni plate) and $\mathrm{PH}_{3}$, even through with high content of water vapor.

\subsection{Conclusions}

The newly developed in-situ technique is utilized to investigate the SOFC degradation behaviors due to the poisoning effect of $\mathrm{PH}_{3}$ contaminant. Coupled with electrochemical measurements, the surface IR emission was carried out to monitor the secondary phase formation and the corresponding polarization effects on cell electrode reaction. Besides the contaminant content, the Ni-YSZ electrode degradation behavior is strongly affected by the operation condition as well as the water vapor content in the fuel gas.

In the presence of steam, $\mathrm{PH}_{3}$ can be converted to phosphoric acid between $700{ }^{\circ} \mathrm{C}$ and $900{ }^{\circ} \mathrm{C}$, which can attack the nickel electrode and YSZ electrolyte. For the operational SOFC, the potential bias across the fuel cell accelerates the phosphoric acid absorption on TPB and reaction with Ni/YSZ electrode. Phosphoric acid reacts with nickel to form nickel phosphate in the Ni-YSZ electrode, which suppresses the electrocatalytic activity of the electrode. If the fuel cell is operating without steam or under OCV (w/o steam), nickel phosphide is formed rather than nickel phosphate, which is still

conductive and shows little deleterious effect on Ni/YSZ electrodes. However, during the 
long-term operation of SOFC, the Ni migration and agglomeration toward the electrode surface is notable, which will bury the YSZ phase and the subsequent P-based secondary phase, irrespective of nickel phosphide or nickel phosphate, will turn into nickel phosphide eventually.

Due to the incorporation of phosphorus into the electrode, Ni migration and the subsequent secondary phase formation, the Ni-YSZ electrode loses its electro-catalytic activity toward oxidation of the fuel gas, while the blockage of the gas diffusion channels occurs as well as the loss of the charge transport pathway. The effects of phosphorous poisoning tend to deteriorate at higher water vapor content in the fuel gas. The present study provides researchers and industry with valuable data for the SOFC thermal and electrochemical modeling. 


\section{Chapter 5: Conclusions and Future Work}

\subsection{Conclusions}

We are among the few groups nationwide who have addressed the issue of SOFCs long-term durability assessment and life prediction. We have identified the mechanisms that degrade SOFCs anode structural properties and developed a long-term SOFC anode structural durability model, which can predict the long-term thermo-mechanical behavior and fuel gas contaminants effects on SOFCs. To validate and develop our structural model, we have developed a novel experimental technique including Sagnac Interferometry and IR thermometry for in-situ surface deformation and temperature measurement for SOFC coupled with cell electrochemical performance measurement under operating conditions.

The developed unique setup consists of a NexTech Probostat ${ }^{\mathrm{TM}}$ SOFC button cell test apparatus integrated with Sagnac interferometric optical setup and infrared thermometer. Notable advantages of this technique are (i) the optical window does not affect the fringe formation, (ii) half wavelength measurement sensitivity, (iii) immune to temperature fluctuation and (iv) immune to vibration, making this optical technology suitable for in-situ, on-line measurement. It is capable of electrode surface deformation and temperature measurement along with the standard cell electrochemical measurements.

The SOFC button cell exposed to hydrogen (w/o steam) or simulated coal syngas is tested under operating conditions. The surface deformation is measured at room temperature and operating temperature to estimate the mechanical properties of anode materials. The cell surface transient temperature is also monitored as a function of loaded current density to investigate the effect of polarization on cell electrode reaction. The experimental data were useful for validation and development the SOFC numerical 
models. From the comparison between experimental and simulation results, it is found that the major source of the surface temperature rise is entropic heating from fuel oxidation and a minor source is ohmic heating. It also demonstrated that the water gas shift reaction provides negligible contributions to the surface temperature variations of SOFCs operating under coal syngas.

The developed in-situ technique is also utilized to investigate the SOFC degradation behaviors due to the poisoning effect of $\mathrm{PH}_{3}$ contaminant. For the operational SOFC in the presence of steam, the potential bias drives $\mathrm{O}^{2-}$ to TPB of Ni/YSZ and caused the formation of Nickel Phosphate (such as $\mathrm{Ni}_{3}\left(\mathrm{PO}_{4}\right)_{2}$ ) in anode, which has a deleterious effect on the SOFC performance. Under OCV (w/o steam) or operating without steam, nickel phosphide is preferred to form instead. In addition, nickel phosphate is reduced into nickel phosphide eventually after the fuel cell long-term operation since Ni migrates and agglomerates toward the electrode surface and buries the YSZ.

Due to the incorporation of phosphorus into the electrode, Ni migration and the subsequent secondary phase formation, the Ni-YSZ electrode loses its electro-catalytic activity toward oxidation of the fuel gas, while the blockage of the gas diffusion channels occurs as well as the loss of the charge transport pathway. The effects of phosphorous poisoning tend to deteriorate at higher water vapor content in the fuel gas. 


\subsection{Future Work}

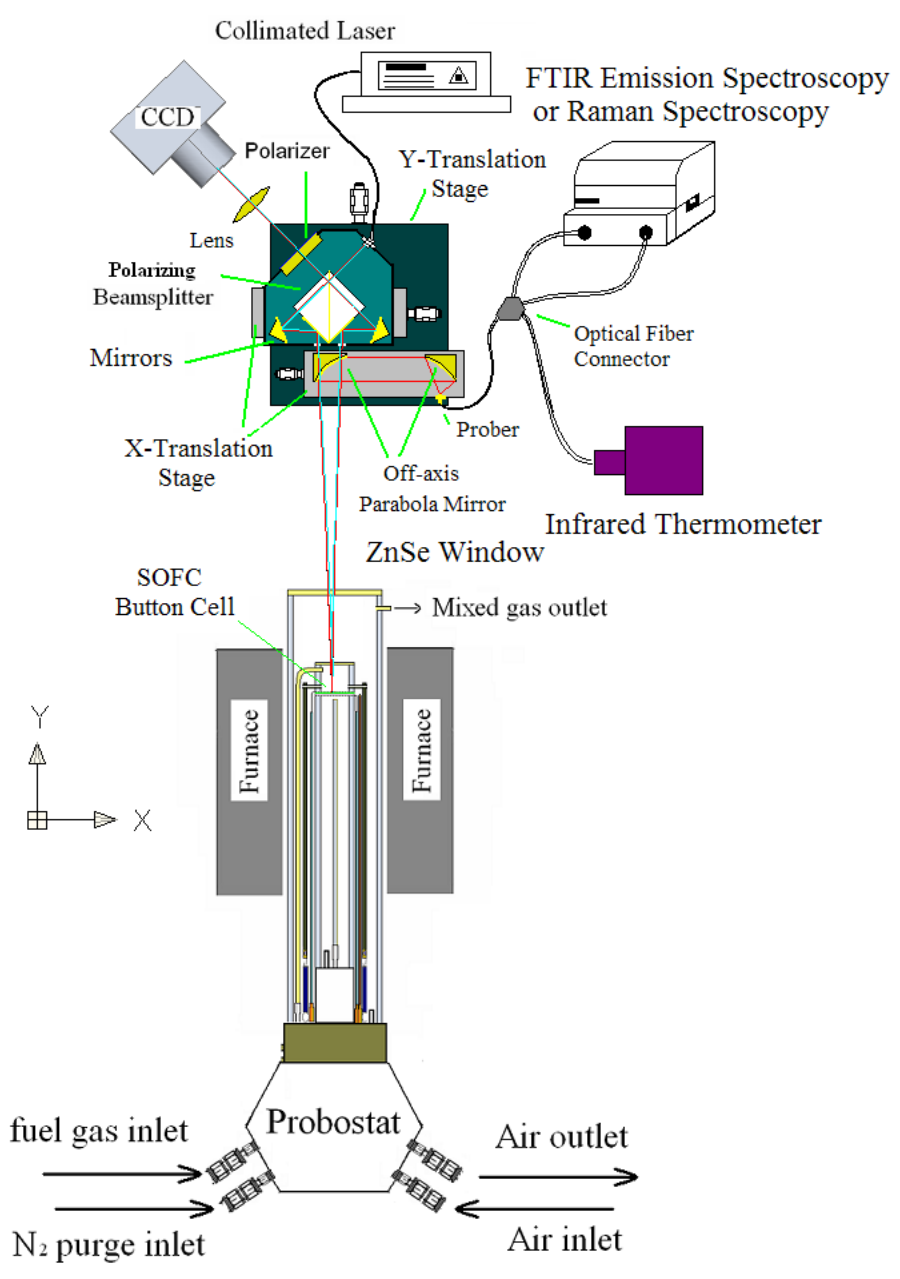

Figure 5. 1 NexTech Probostate ${ }^{\text {TM }}$ integrated with Sagnac interferometry FTIR Emission Spectroscopy and IR thermometer

Based on the present work, further researches are suggested:

1. The unique optical technique will be further refined, and a portable test unit will be assembled. As shown in Figure 5.1, this portable optical unit not only can be utilized for in-situ surface and temperature measurement on multiple location of SOFC button cell under operating conditions, but also is convenient to integrate with Fourier 
transform infrared spectroscopy (FTIR) or Raman spectroscopy for in-situ analysis of absorbed species and electrochemical reactions on electrode surface, through the incorporated optical fiber connector. The development of our optical instrumentation shows potential commercial potential not only for SOFC research but also for many other areas of materials research.

2. In-situ analysis of absorbed species and electrochemical reactions and the corresponding reaction intermediates on electrodes using improved test apparatus with FTIR or Raman spectroscopy during the operation of SOFCs in coal syngas. Fundamental researches are needed for further understanding the coal syngas contaminant effects, such as the transient secondary phase formation of the Ni-YSZ in $\mathrm{PH}_{3}$ contaminant. Such study is to provide direct insight into the processes likely to occur in operational SOFC.

3. Apply Sagnac interferometry to measure SOFC button cell surface deformation during long-term operation, and investigate the material degradation mechanisms in SOFC anode material including thermo-mechanical and syngas contaminants effects. Such research should be focused on the following areas:

(i) Initial Degradation Threshold (Ko)

The initial degradation threshold $\left(\mathrm{K}_{\mathrm{o}}\right)$ will be estimated experimentally. During long-term SOFC operation, the button cell should be subjected to the gradually increasing pressure loading at operating temperature. The corresponding surface deformation and change of slope will be measured by the integrated Sagnac interferometery optical setup, a curve similar to the one shown in Figure 5.1 can be expected to be obtained.

After each pressure increment, the out-of-plane deformation and change of slope at a particular location will be compared with the results obtained from analytical Equations 
(3.3) - (3.6), and the results obtained from FEA simulation without degradation consideration. The particular load (applied pressure) when the results are different between the experimental and analytical solution (and FEA), is the initiation of the degradation in the anode material as shown in (Figure 5.2), which can be used to determine the initial degradation variable.

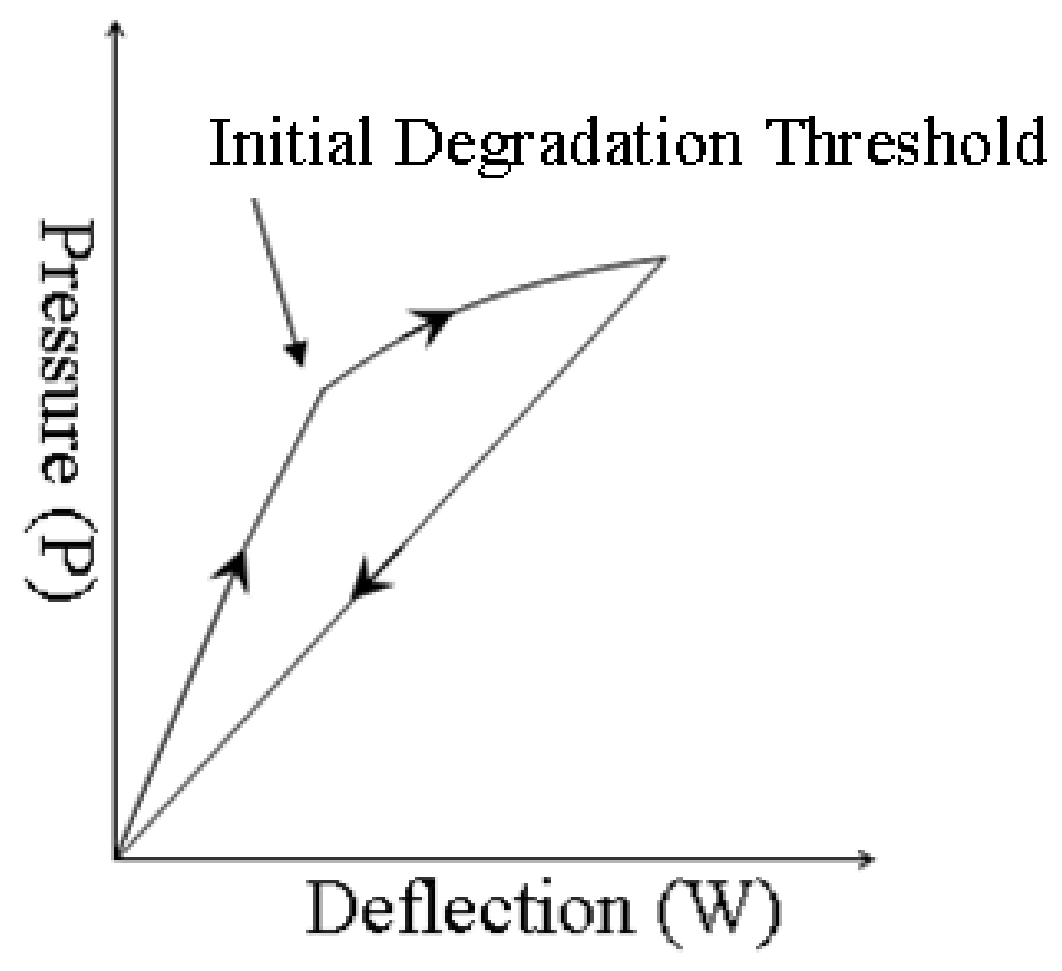

Figure 5. 2 Determining of the initial degradation threshold

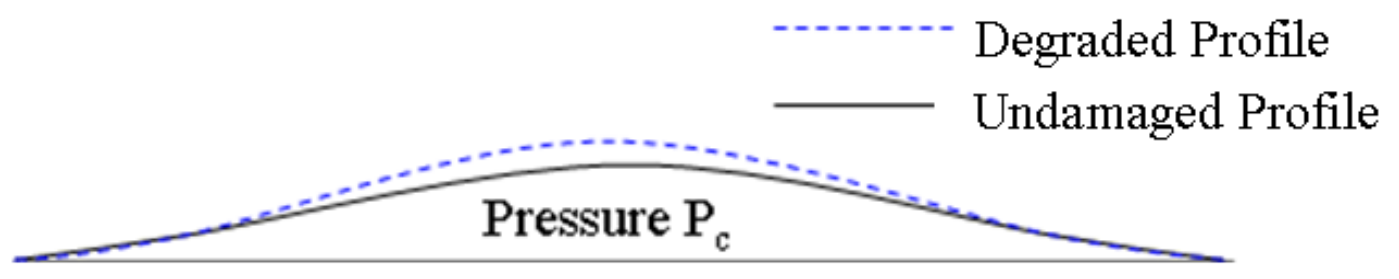

Figure 5. 3 Initiation of degradation at critical pressure Pc 
(ii) Thermo-Mechanical Degradation Variable $\left(\mathrm{D}_{\mathrm{m}}\right)$

$D_{m}$ is associated with the cell degradation due to the mechanical loads and thermal aging effect. After heat treatment and reduction, the button cell should be operated under hydrogen and/or clean syngas. During long-term operation, the button cell is subjected to uniform pressure at various time intervals, and the corresponding out-of-plane deformation will be obtained. Without contaminants attack, the anode material degraded hardening or softening, due to thermo-mechanical effect only. According to the surface deformation changes over time, thermo-mechanical degradation variable of button cell will be compared to evaluate changes of the material mechanical properties.

(iii) Syngas Contamination Degradation Variable $\left(D_{c}\right)$

$D_{c}$ is associated with the cell degradation due to the syngas contaminants effect on anode material. To determine this variable, a button cell will be operated under syngas with different level of contaminants (such as P) instead of clean syngas, while keeping the rest of operation condition the same. In addition to thermo-mechanical effect, the button cell suffers from the attack of syngas contaminants. The cumulative effect of all degradation mechanisms is defined as effective degradation parameter (D), which is showed in Equation (2.8). Via the same test procedure, the surface deformation changes will be used to determine the effective degradation parameter (D) and to deduce the syngas contamination degradation variable $\left(D_{c}\right)$. The depth of penetration of trace contaminants will be determined via post test methods, such as SEM, EDX and XPS. These material structural parameters determined via experiments will be utilized to verify, validate and develop structural durability model of SOFCs, which is performed by Dr. Gulfam Iqbal in our research group, and predict the SOFC service life. 


\section{References}

[1] S. Primdahl and M. Mogensen, J. Electrochem. Soc, 144, 1997, 3408

[2] A. Weber, B. Sauer, A.C. Muller, D. Herbstritt and E. Ivers-Tiffee, Solid State Ionics, $543,2002,152-153$

[3] J. Liu and S. A. Barnett, Solid State Ionics, 158, 2003, 11

[4] Z. F. Zhou, C. Gallo, M. B. Pague, H. Schobert and S. N. Lvov, J .Power.Sources, $133,2004,181$

[5] J. Staniforth and R. M. Ormerod, Ionics, 9, 2003, 336

[6] J. P. Trembly, A.I. Marquez, T.R. Ohrn and D. J. Bayless, J. Power Sources, 158, 2006, 2638

[7] R. Suwanwarangkul, E. Croiset, M. W. Fowler, P.L. Douglas, E. Entchev and M. A. Douglas, J. Power Sources, 161, 2006, 308

[8] M. C. Williams, J. Strakey and W. Sudoval, J. Power Sources, 159, 2006, 1241

[9] O. Marina, L. Pederson, C. Coyle, EC Thomsen, D. Edwards, C Nguyen, G. Coffey, Proceeding of the $9^{\text {th }}$ Annual Solid State Energy Conversion Alliance (SECA) Workshop, Pittsburgh, PA, 2008.

[10] O. Marina, L. Pederson, G. Coffey, C. Coyle, Mini Symposium, Morgantown WV, 2007.

[11] G. Krishnan, P. Jayaweera, J. Perez, SRI Technical Progress Report, 2006. 
[12] G. Krishnan, Proceeding of the $8^{\text {th }}$ Annual SECA Review Workshop, San Antonio, TX, 2007

[13] J. P. Trembly, R. S. Gemmen, D. J. Bayless, J. Power Sources 163, 2007, 986-996

[14] J. P. Trembly, R. S. Gemmen, D. J. Bayless, J. Power Sources 171, 2007, 818-825

[15] J. P. Trembly, R. S. Gemmen, D. J. Bayless, J. Power Sources 169, 2007, 347-354

[16] K. Haga, Y. Shiratori, K. Ito, et al., J. Electrochem. Soc., 155(12), 2008, B1233B1239

[17] F. N. Cayan, M. J. Zhi, S. R. Pakalapati, et al., J. Power Sources 185, 2008, 595-602

[18] E. Lara-Curzio, M. Radovic, R. M. Trejo, K. An, C. R. Luttrell, and T. R. Watkins, Fuel Cell Program Annual Report, 2005, 82-89

[19] G. Iqbal, H. Guo, and B. Kang, Proceeding of the Twenty-Fifth Annual International Pittsburgh Coal Conference, Pittsburgh, PA, September 29- October 2, 2008.

[20] D. Sarantaridis, and A. Atkinson, Fuel Cells, 07 [3], 2007, 246-258

[21] D. Larrain, J. Van herle, D. Favrat, J. Power Sources, 161[1], 2006, 392-403

[22] G. Stathis, D. Simwonis, F. Tietz, A. Moropoulou, and A. Naoumides, J. Mater. Res. $17[5], 2002,951-958$ 
[23] H. Apfel, M. Rzepka, H. Tu, and U. Stimming, J. Power Sources, 154, 2006, 370378 ,

[24] A. Nakajo, C. Stiller, G. Harkegard, and O. Bolland, J. Power Sources, 158, 2006, $287-294$

[25] J. Laurencin, B. Morel, Y. Bultel, and F. Lefebvere-Joud, Fuel Cell, 06, 2006, 64-70

[26] A. Selimovic, M. Kemm, T. Torisson, and M. Assadi, J. Power Sources, 145, 2005, $463-469$

[27] K. Tsukuma, Y. Kubota, and T. Tsukidate, Advances in Ceramics, Vol. 12, Science and Technology of Zirconia II. Edited by A. H. Heuer and L. W. Hobbs. American Ceramic Society, Columbus, OH, 1984

[28] D. Fouquet, A.C. Muller, A. Weber, E. Ivers-Tiffe, Proceedings $5^{\text {th }}$ European SOFC Forum, (Ed. J. Huijsmans), Lucerne, Switzerland, 467 (2002)

[29] Y. Murakami, I. Nagano, H. Yamamoto, and H. Sakata, Journal of Materials Science Letters, 16[20], 1997, 1686-1688

[30] B. Nghiep Nguyen, Brian J Koeppel, Said Ahzi, Mohammad A Khaleel, and Prabhakar Singh. Journal of the American Ceramic Society , 89[4], 2006, 1358-1368

[31] M. Zhi, Ph.D. thesis, West Virginia University, Morgantown, WV, 2011

[32] F. Jurado, Fuel Cells, 4, 2004, 378

[33] Cummins Power Generation, 3rd SECS annual workshop, 2002, Washington, DC 
[34] S. McIntosh and R. J. Gorte, Chem. Rev., 104, 2004, 4845

[35] S. P. Jiang and S. H. Chan, J. Mater. Sci., 39, 2004, 4405

[36] W.Vielstich, A. Hubert, M. Gasteiger and A. Lamm, Handbook of Fuel CellsFundamentals, Technology and Applications, Chapter 74, Wiley, New York (2003)

[37] E .Riensche, U Stimming and G. Unverzagt, J.Power.Sources, 73, 1998, 251

[38] A. Boudghene Stambouli, E. Traversa, Renewable and Sustaniable Energy Reviews, 6, 2002, 433-455

[39] R. O. Hayre, S. W .Cha, W. Colella and F. B. Prinz, Fuel Cell Fundamentals, Chapter 8, 244, Wiley, New York (2005)

[40] J. W. Yan, H. Matsumoto, M. Enoki and T. ishihara, Electrochemical and SolidState Letters, 8, 2005, A 389.

[41] Fuel cell materials by Nextech materials. February 2011. http://www.fuelcellmaterials.com/pdf/Cerias\%2007-08.pdf

[42] C. Brahima, A. Ringuedéa, E. Gourbaa, M. Cassira, A. Billardb and P. Brioisb, J. Power Sources, 156, 2006, 45

[43] S. P. Simner, J. P. Shelton, M. D. Anderson and J. W. Stevenson, Solid State Ionics, $161,2003,11$

[44] F. Tietz, V.A.C. Haanappel, A. Mai, J. Mertens and D. Stöver, J. Power Sources, 
$156,2006,20$

[45] K. J. Yoon, P. Zink, S. Gopalan, and U. B. Pal, J. Power Sources, 172, 2007, 39

[46] A.V. Virkar, et al., Solid State Ionics, 131, 2000, 189.

[47] M. mogensen, K. Kammer, Annu. Rev. Mater. Res. 33, 2003, 321

[48] O. A. Marina, M. Mogensen, Appl. Catal. A. 189, 1999, 117.

[49] S. Park, J. M. Vohs, R. J. Gorte, Nature 404,2000, 265.

[50] J. P. Trembly, A.I. Marquez, T.R. Ohrn and D. J. Bayless, J. Power Sources, 158, 2006,2638

[51] M. Radovic, and E. Lara-Curzio, Mechanical Properties of Tape Cast Nickel-Based Anode Materials for Solid Oxide Fuel Cells before and after Reduction in Hydrogen, Acta Materialia, 52(20), 2004, 5747-5756

[52] A. Selcuk, G. Merere, and A. Atkinson, J. Mater. Sci., 36(5), 2001, 1173-1182

[53] A. Verma, A. D. Rao, and G. S. Samuelsen, J. Power Sources, 158, 2006, 417-427

[54] C. Higman, and M. van der Burgt, Gasification, Elsevier, Amsterdam, ISBN 0-75067707-4, 2003, 147-154

[55] J. Ratafia-Brown, L. Manfredo, J. Hoffmann and M. Ramezzan, Major Environmental Aspects of Gasification-Based Power Generation Technologies, Final Report, U.S. Department of Energy, 2002 
[56] H. Guo, G. Iqbal and B. Kang, Int. J. Appl. Ceram. Technol, 8[1], 2011, 68-73

[57] M. Zhi, F. N. Cayan, I. Celik, R. Gemmen, S. R. Pakalapati and N. Q. Wu, Fuel Cells, 10, 2010, 174

[58] M. J. Zhi, X. Q. Chen, H. Finklea, I. Celik, N. Q. Wu, J. Power Sources, 183, 2008, 485

[59] C. C. Xu, J. W. Zondlo, H. O. Finklea, O. Demircan, M. G. Gong and X. B. Liu, J. Power Sources, 193, 2009, 739

[60] C. C. Xu, J. W. Zondlo, M. G. Gong and X. B. Liu, J. Power Sources, 196, 2011, 116

[61] O. Demircan, C. C. Xu, J. W. Zondlo and H. O. Finklea, J. Power Sources, 194, 2009,214

[62] O. Demircan, W. Zhang, C. C. Xu, J. W. Zondlo and H. O. Finklea, J. Power Sources, 195, 2010, 3091

[63] O. A. Marina, C. A. Coyle, E. C. Thomsen, D. J. Edwards, G. W. Coffey, L.R. Pederson, Solid State Ionics, 181, 2010, 430

[64] W. Lu, X. Sun, L.R. Pederson, O. A. Marina, M. A. Khaleel, J. Power Sources, 195, 2010,7140

[65] C. A. Coyle, O. A. Marina, E. C. Thomsen, D. J. Edwards, C.D. Cramer, G. W. Coffey and L. R. Pederson, J. Power Sources., 173, 2009, 730 
[66] K. Haga, Y. Shiratori, K. Ito, et al., J. Electrochem. Soc., 155(12), 2008, B1233B1239

[67] G. Iqbal, Ph.D. thesis, West Virginia University, Morgantown, WV, 2011

[68] D. Larrain, J. Van herle, D. Favrat, J. Power Sources, 161[1], 2006, 392-403

[69] W. X. Li, K. Hasinska, M. Seabaugh, et al., J. Power Sources, 138, 2004, 145-155

[70] A. Nakajo, C. Stiller, G. Harkegard, and O. Bolland, J. Power Sources, 158, 2006, 287-294.

[71] J. W. Zwanzigera and U. Werner-Zwanziger, Journal of Applied Physics, 99, 2006, 083511

[72] K. Chen, Z. Lu, N. Ai, et al., J. Power Sources, 160(1), 2006, 436-438

[73] H. Moon, S. D. Kim, S. H. Hyun, H. S. Kim, International Journal of Hydrogen Energy, 33, 2008, 1758-1768

[74] F. Lofaj, G.V. Blessing and S.M. Wiederhorn, Journal of the American Ceramic Society, 2003

[75] G. Robert, A. Kaiser, and E. Batawi, in 6th European Solid Oxide Fuel Cell Forum Proceedings, M. Mogensen, Editor, p. 193, European Fuel Cell Forum, Oberrohrdorf, Switzerland, 2004

[76] D. Fouquet, A.C. Muller, A. Weber, E. Ivers-Tiffe, "Proceedings $5^{\text {th }}$ European SOFC Forum, (Ed. J. Huijsmans), Lucerne, Switzerland, p. 467, 2002 
[77] G. Stathis, D. Simwonis, F. Tietz, A. Moropoulou, and A. Naoumides, J. Mater. Res. 2002

[78] D. Sarantaridis, and A. Atkinson, Fuel Cells, 07 [3], 2007, 246-258

[79] V. M. Janardhanan, O. Deutschmann, J. Power Sources, 162, 2006, 1192-1202

[80] T. Nishino, H. Iwai, K. Suzuki, Journal of Fuel Cell Science and Technology, 3, 2006, 33-44

[81] R. S. Gemmen, J. Trembly, J. Power Sources, 161, 2006, 1084-1095

[82] S. Nagata, A. Momma, T. Kato, Y. Kasuga, J. Power Sources, 101, 2001, 60-71

[83] H. Zhu, R. J. Kee, V. M. Janardhanan, O. Deutschmann, D. G. Goodwin, Journal of the Electrochemical Society, 152, 2005, A2427-2440

[84] E. S. Hecht, G. K. Gupta, H. Zhu, et al., Applied Catalysis A: General, 295, 2005, $40-51$

[85] S. R. Pakalapati, F. Elizalde-Blancas, I. B. Celik, Proceedings of the MiniSymposium "Coal Based Fuel Cell Technology: Status, Needs and Future Applications". Morgantown WV, October 11-12, 2007

[86] L. M. Kachanov, Izv. Akak. Nauk. S.S.R. Otd. Tech. Nauk., 8, 1958, 26-31.

[87] Y. C. Xiao, International Journal of Fatigue, 41, 2004, 41-67 
[88] G. Iqbal, H. Guo, and B. S. Kang, Proceeding of the Twenty-Fifth Annual International Pittsburgh Coal Conference, Pittsburgh, PA, September 29- October 2, 2008.

[89] G. Iqbal, H. Guo, and B. S. Kang, Int. J. Appl. Ceram. Technol., 8[1], 2011, 13-22

[90] M.E.Orazem, B.Tribollet, Electrochemical Impedance Spectroscopy, 63, Wiley, New York (2008)

[91] A. Bieberle, L. P. Meier, ande L. J. Gauckler, J. Electrochem. Soc. 148, 2001, A646A656

[92] EG\&G Technical Services, Inc, Science Applications International Corporation, Fuel Cell Handbook, 7th ed., Morgantown, WV: U.S Dept. of Energy, Office of Fossil Energy, National Energy Technology Laboratory, November, 2004

[93] X. Y. Lu, P. W. Faguy, and M. L. Liu, J. Electrochem. Soc. 149[10], 2002, A1293A1298

[94] T. Murai, K. Yashiro, A. Kaimai, et al., Solid State Ionics, 176, 2005, 2399-2403

[95] O. S. N. Sum, E. Djurado, T. Pagnier, et al., Solid State Ionics, 2005, 176, 25992607

[96] E. Lara-Curzio, and M. Radovic, In Fossil Energy Program Annual Progress Report for April 2002 through March 2003, ORNL Internal Report ORNL/Tm-2003/119

[97] M. B. Pomfret, J. C. Owrutsky, and R. A. Walker, J. Phys. Chem. B, 110[35], 2006, 17305-17308 
[98] M. L. Liu, X.Y.Lu, and P. Faguy, in Proceedings of The $8^{\text {th }}$ International Symposium on SOFCs, Editor, S.C. Singhal and M. Dokiya, The Electrochemical Society, Pennington, NJ, PV 07, 2003, 1132-1146

[99] M. B. Pomfret, J. C. Owrutsky, and R. A. Walker, Anal. Chem., 79, 2007, 23672372

[100] S. Miyoshi, A. Kaimai, H. Matsumoto, et al., Solid State Ionics, 175, 2004, 383386

[101] M. Adzic, M.V. Heitor, D. Santos, Journal of Applied Electrochemistry 27, 1997, $1-8$

[102] D. J. L. Brett, P. Aguiar, R. Clague, et al., J. Power Sources, 166, 2007, 112-119

[103] O. S. N. Sum, E. Djurado, T. Pagnier, et al., Solid State Ionics, 176, 2005, 25992607

[104] G. Sagnac, Acadamie der Sciences, Paris Comptes Randus, 157, 1913, 708-710.

[105] A. Huang, Applied Optics, 33[26], 1994, 6254-6267

[106] B. S. Kang and S.M. Anderson, Experimental Mechanics, 41(1), 2001, 84-91

[107] J.H Nicholas et al, MIT Press (1969).

[108] G. Iqbal, H. Guo, and B. S. Kang, Proceeding of the Twenty-Fifth Annual International Pittsburgh Coal Conference, Pittsburgh, PA, September 29- October 2, 2008. 
[109] G. Iqbal, H. Guo, and B. S. Kang, Int. J. Appl. Ceram. Technol., 8[1], 2011, 13-22

[110] S. Timoshenko and S. Woinowsky-Krieger, McGraw- Hill Book Company, Inc. (1959)

[111] EG\&G Technical Services, Inc, Science Applications International Corporation, Fuel Cell Handbook, 7th ed., Morgantown, WV: U.S Dept. of Energy, Office of Fossil Energy, National Energy Technology Laboratory, November, 2004

[112] E. F. Sverdrup, C. J. Warde, and A.D. Glasser, in "From Electrocatalysis to Fuel Cells,” edited by G. Sandstede, University of Washington Press, Seattle, WA, 1972

[113] S. Pakalapati, A New Reduced Order Model for Solid Oxide Fuel Cells, Ph.D. thesis, West Virginia University, Morgantown, WV, 2006

[114] S. R. Pakalapati, F. Elizalde-Blancas, I. B. Celik, Proceedings of the MiniSymposium “Coal Based Fuel Cell Technology: Status, Needs and Future Applications". Morgantown WV, October 11-12, 2007

[115] J. O. M. Bockris and S. Srinivasan, "Fuel Cells: Their Electrochemistry", pp. 176229, McGraw-Hill Book Company, Inc., New York, 1969

[116] R.H. Song, C.S. Kim, and D. R. Shin, J. Power Sources., 86, 2000, 289-293

[117] F. Zhao, A. V. Virkar, J. Power Sources., 141, 2005, 79-95

[118] M. J. Zhi, X. Q. Chen, H. Finklea, I. Celik, N. Q. Wu, J. Power Sources, 183, 2008, 485 
[119] T. I. Koranyi, Z. Vit, D. G. Poduval, R. Ryoo, H. S. Kim, and E. J. M. Hensen, J. Catal. 253, 2008, 119-131

[120] Y. K. Lee, and S. T. Oyama, J. Catal. 239, 2006, 376-389

[121] S. T. Oyama, J. Catal. 216,2003, 343-352

[122] F. N. Cayan, Ph.D. thesis, West Virginia University, Morgantown, WV, 2011

[123] B. C. Eigenbrodt, M. B. Pomfret, D. A. Steinhurst, J. C. Owrutsky, And R. A. Walker, J. Phys. Chem. C, 115, 2011, 2895-2903

[124] "Infrared Temperature measurement: Theory and Application", Technical Reference Section, Z63-Z66

[125] "Principle of Infrared Thermometer", Technical Reference Section, Z59-Z62

[126] S.P. Jiang, S.P.S. Badwal, Solid State Ionics, 123, 1999, 209

[127] M.Watanabe, H. Uchida, M. Yoshida, J. Electrochem. Soc. 144, 1997, 1739.

[128] X. Zhu, K. Sun, S. L, N. Zhang, Q. Fu, X. Chen and Y. Yuan, Electrochimica Acta, $54,2008,862-867$

[129] M.E. Perry, M.J. Sever, S.A. Barnett, Solid State Ionics 148, 2002, 27 


\section{Appendix}

Author's publication list during Ph.D study

\section{Journal Papers:}

1. Patent: " $\mathrm{CO}_{2}$ Decomposition via Oxygen Deficient Ferrite Electrolyser Cell", (pending).

2. Huang Guo, Gulfam Iqbal, and Bruce S. Kang, "Development of an In-situ Surface Deformation and Temperature Measurement Technique for SOFC Button Cell," International Journal of Applied Ceramic Technology, 7 [1] 55-62 (2010).

3. Gulfam Iqbal, Huang Guo, Bruce S. Kang, and Olga A. Marina, "Durability Prediction of Solid Oxide Fuel Cell Anode Material under Thermo-mechanical and Fuel Gas Contaminants Effects," International Journal of Applied Ceramic Technology, 8 [1] 13-22 (2011).

4. Huang Guo, Gulfam Iqbal, and Bruce S. Kang, "Effects of $\mathrm{PH}_{3}$ Contaminant on SOFC Performance and Related Anode Surface Temperature Measurements," International Journal of Applied Ceramic Technology, 8 [1] 68-73 (2011).

5. Huang Guo, Gulfam Iqbal, and Bruce S. Kang, "Investigation of Secondary Phases due to $\mathrm{PH}_{3}$ Interaction with SOFC Anode," Advances in Materials Science for Environmental and Nuclear Technology II: Ceramic Transaction, Volume 227 5160, 2011.

6. Gulfam Iqbal, Suryanarayana Raju Pakalapati, Francisco Elizalde-Blancas, Huang Guo, Ismail Celik, and Bruce S. Kang, "PEN Structure Thermal Stress Analysis for Planar-SOFC Configurations under Practical Temperature Field," Advances in Materials Science for Environmental and Nuclear Technology II: Ceramic Transaction, Volume 227 61-68, 2011.

7. Bruce Kang, Huang Guo, Gulfam Iqbal, Ayyakkanna Manivannan, " $\mathrm{CO}_{2}$ Conversion into C/CO using ODF Electrodes with SOEC," Accepted by The American Ceramic Society's Ceramic Transactions volume. 


\section{Conference:}

1. Huang Guo, Gulfam Iqbal, and Bruce S. Kang, Proceeding of $35^{\text {th }}$ International Conference and Exposition on Advanced Ceramics and Composites, Daytona Beach Florida, January 23-28, 2011.

2. Huang Guo, Gulfam Iqbal, and Bruce S. Kang, Proceeding of 2010 TMS Annual Meeting \& Exhibition, Seattle, WA, February 14-18, 2010.

3. Huang Guo, Gulfam Iqbal, and Bruce S. Kang, Proceeding of ASME $20108^{\text {th }}$ Fuel Cell Science, Engineering \& Technology Conference, Brooklyn, New York, June $14-16,2010$

4. Huang Guo, Gulfam Iqbal, and Bruce S. Kang, Proceeding of Material Science \& Technology 2010, Houston, Texas, Oct. 17-21, 2010.

5. Harry O. Finklea, Bruce Kang, Huang Guo, Gulfam Iqbal, Ismail Celik and Raju Pakalapati, Proceeding of $239^{\text {th }}$ American Chemical Society national Meeting \& Exposition, San Francisco, Ca, march 21-25, 2010.

6. Huang Guo, Gulfam Iqbal, and Bruce S. Kang, Proceeding of Material Science \& Technology 2009, Pittsburg, PA, October 25-29, 2009.

7. Huang Guo, Gulfam Iqbal, and Bruce S. Kang, Proceeding of the ASME $7^{\text {th }}$ International Fuel Cell Science, Engineering \& Technology Conference, Newport Beach, CA, June 8-10, 2009.

8. Huang Guo, Gulfam Iqbal, and Bruce S. Kang, 2009 Society for Experimental Mechanics (SEM) Annual Spring Conference, Albuquerque, NM, June 1-4, 2009.

9. Gulfam Iqbal, Huang Guo, and Bruce S. Kang, Proceeding of The Mineral, Metals \& Materials Society conference 2009, San Francisco, CA, February 15-19, 2009.

10. Huang Guo, Gulfam Iqbal, Rajiv Dastane, Bruce S. Kang, Proceeding of the Twenty-Fifth Annual International Pittsburgh Coal Conference, Pittsburgh, PA, September 29- October 2, 2008.

11. Huang Guo, Rajiv Dastane, Gulfam Iqbal, Bruce S. Kang, Proceeding of Material Science \& Technology 2008, Pittsburg, PA, October 5-9, 2008. 